\title{
Westinghouse Hanford Company Health and Safety Performance Report Fourth Quarter Calendar Year 1995
}

Safety

Radiological Control

Date Published

March 1996

Prepared for the U.S. Department of Energy Assistant Secretary for Environment, Safety and Health 


\section{RELEASE AUTHORIZATION}

Document Number: WHC-SP-0564, Rev. 40

Westinghouse Hanford Company Health and Safety

Document Title: $\quad$ Performance Report - Fourth Quarter Calendar Year 1995

Release Date: $\quad 2 / 22 / 96$

This document was reviewed following the procedures described in WHC-CM-3-4 and is:

APPROVED FOR PUBLIC RELEASE

WHC Information Release Administration Specialist:

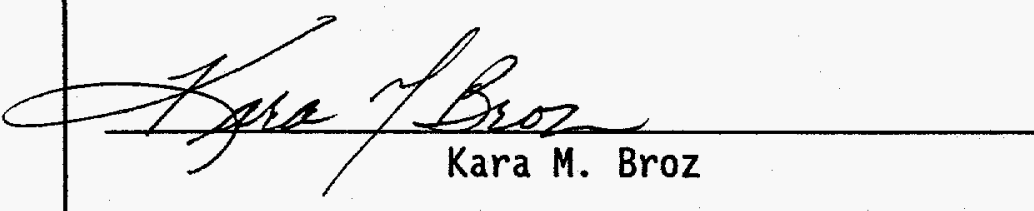

February 22, 1996 


\section{DISCLAMMER}

Portions of this document may be illegible in electronic image products. Images are produced from the best available original document. 
Document Title: Westinghouse Hanford Company Health and Safety Performance Report WHC-SP-0564-40

Prepared by:

Approved by:

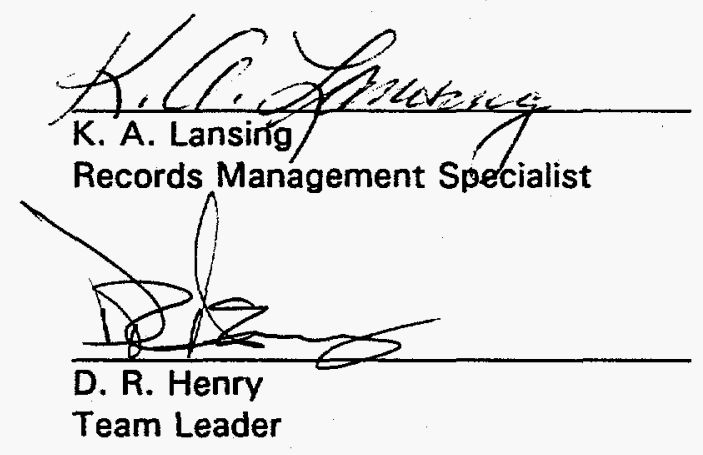

$$
\frac{2-21-96}{\text { Date }}
$$

Approved by:
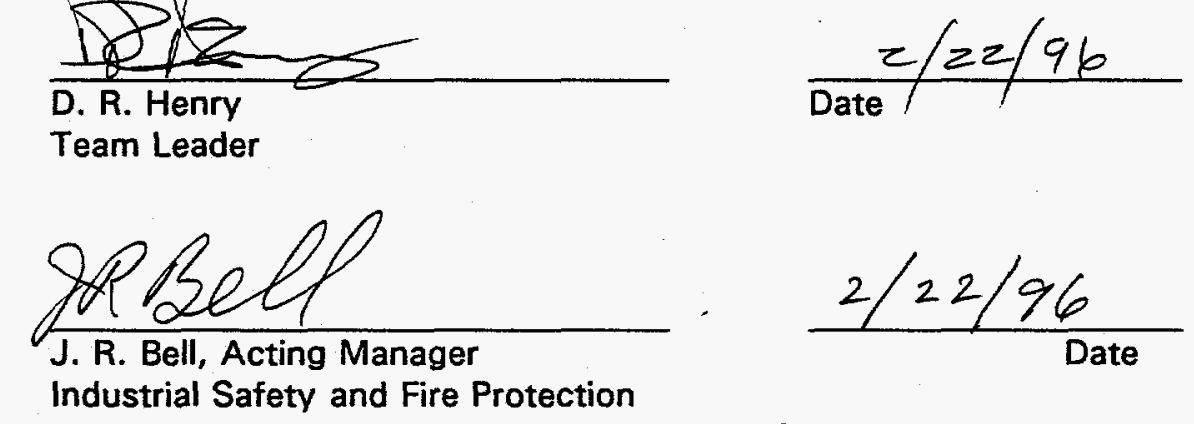
WHC-SP-0564-40

This page intentionally left blank. 


\section{ACKNOWLEDGEMENTS}

Authors, contributors, and reviewers of the Westinghouse Hanford Health and Safety Performance Report are all a part of the Emergency, Safety, Quality Services organization.

Section 1, "ALARA," O. D. Berglund, Editor

Radiological Control

Radiological Engineering and ALARA

O. D. Berglund, ALARA Coordinator

R. E. Elder, Senior Health Physicist

Section 2, "INDUSTRIAL SAFETY," L. J. Green, Editor

Safety

Industrial Safety and Fire Protection

C. L. Brasker, Accident Investigator

L. J. Green, Records Management Specialist

V. L. Estes, Engineer

T. A. O'Neal, Records Management Specialist

E. L. Stairet, Accident Investigator

R. W. Westenberg, Accident Investigator

D. J. Wiatrak, VPP Program Coordinator

L. Zaring, Records Management Specialist

Industrial Hygiene Programs

S. K. Alexander, Industrial Hygienist

R. A. Moorman, Industrial Hygienist

Section 3, "RADIOLOGICAL SAFETY," K. A. Lansing, Editor

Radiological Control

T. W. Hogg, Program Engineer

Radiological Engineering and ALARA

Dosimetry

J. S. Konyu, Plant Engineer

B. L. Baumann, Internal Dosimetry Advisor

D. S. Cunningham, Principal Health Physicist

D. J. Gateley, Records Management Specialist

Safety

Industrial Safety and Fire Protection

K. A. Lansing, Records Management Specialist

S. L. Thackham, Clerk 
WHC-SP-0564-40

This page intentionally left blank. 


\section{MANAGEMENT SUMMARY}

WHC once again achieved significant improvement in its overall safety performance as reflected by the injury/illness incidence rates. Incidence rates with one exception (Restricted Work Cases Only Incidence Rate) reflect sharp reductions. The increase in the Restricted Work Case Incidence Rate appears to be the result of effective case management activity and the return to work in a partial duty capacity of employees who may otherwise have been off work due to a work-related injury/illness (Page 2-9).

During CY 1995, all 15 WHC sitewide ALARA performance goals were completed on or ahead of schedule. One of the completed goals related to the WHC ALARA Committees revising or developing ALARA plans/procedures to comply with the requirements of 10 CFR 835 . For detailed information relating to the status of CY 1995 WHC sitewide ALARA performance goals, refer to Appendix A-1 of this report.

Investigations of ALARA Tracking and Management System dosimeter result anomalies revealed a concerted effort to maintain radiation exposure in the workplace ALARA. Although anomalies were noted, they resulted in exposures $w$ ell below the administrative guidelines established by WHC (Page 1-9).

This quarter, each division completed activity in support of the CY 1995 President's Accident Prevention Council (PAPC) Safety and Health Goals. Planning commenced for development of CY 1996 PAPC Goals utilizing active employee participation and involvement in their development. At the December meeting of the PAPC, the proposed 1996 goals and objectives were approved. Representatives from each WHC division Accident Prevention Council met several times during the quarter to create a framework for continuous improvement initiatives for 1996.

The Industrial Hygiene Programs group established Subject Matter Experts for Industrial Hygiene programs to interface with facilities from a "company perspective," provide technical expertise and regulatory interpretation, support effective and timely responses to major issues, and enhance program-wide communication efforts (Page 2-6).

Phase I of the Enhanced Work Planning Demonstration Project has been successfully completed at the Hanford Site. This is a cooperative project among WHC, DOE-RL, DOE-HQ, and HEHF to evaluate concepts and approaches designed to improve work planning from both operations and worker protection standpoints. Enhancements address teamwork and worker involvement in planning, integration of exposure assessment, and coordination of information flow between medical, industrial hygiene and the worker. 


\section{MANAGEMENT SUMMARY (Continued)}

WHC identified areas to improve efficiency and cost-effectiveness of activities related to respiratory protection services and implemented workscope changes to streamline the process (Page 2-7).

Expo '96 will be held April 10 through 11, 1996, at the Benton-Franklin County Fairgrounds. It will target the "grassroots" workforce during the daytime and evenings will take on a theme of offthe-job, family safety. The event will provide attendees with an opportunity to participate in interactive demonstrations by on- and offsite personnel and to view and/or partake of approximately 80 different exhibits and demonstrations which illustrate how safety equipment, as well as health and wellness programs can protect an individual at work and off-the-job (Page 2-8).

The cumulative CY 1995 total recordable case incidence rate (3.64) is 10 percent below the company's CY 1994 rate (4.02), and 2\% above the DOE CY 1991-93 Average (3.73). (Figure 2-5)

Figure 2-3 provides the CY 1995 breakdown, by departments, of the lost workday away and restricted workday incidence rates. The combined cumulative CY 1995 lost workday away (6.35) and restricted workday (14.25) incidence rates of 20.61 are 55 percent below the DOE 1991-93 Average (45.90).

The Figure 3-2-1 chart data includes WHC, BCSR, and ICF KH employee radiological exposure. The CY 1995 total exposure is 181 person rem. This represents the exposure of 2,017 quarterly-badged employees (65 person rem), an average of 850 monthly-badged employees (104 person rem), and 4,838 annually badged employees (12 person rem). Radiological work increased during $\mathrm{CY} 1995$ which is reflected in the higher exposure totals. This increase is mainly attributed to characterization work, and ICF KH work at C-106 and in the 300 Area for PNL.

There were three instances of loss of contamination control during the calendar quarter involving eight workers where internal dosimetry follow-up was performed. Intakes greater than 100 mrem CEDE were detected for two of these employees. Intakes below 100 mrem CEDE were assessed for four additional workers (Page 3-6).

There were six skin contaminations and 24 clothing contaminations reported during the fourth calendar quarter in all WHC-managed facilities. The totals for the year are: 29 skin and 79 clothing contaminations. The increased work activities in Tank Farms, PFP, and Analytical Laboratory is reflected in the number of personal contaminations this the year. An excellent case management program at B Plant resulted in the notable improvement at that facility (Page 3-10). 
TABLE OF CONTENTS

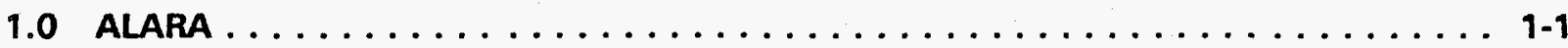

1.1 WESTINGHOUSE HANFORD COMPANY ALARA GOALS $\ldots \ldots \ldots \ldots \ldots \ldots 1-1$

1.1.1 Sitewide ALARA Performance Goals . . . . . . . . . . . . 1-2

1.1.2 Facility/Organization ALARA Goal Performance ........... 1 .

1.2 ALARA/CCIP PROGRAM IMPLEMENTATION, PROGRESS, AND ACHIEVEMENTS $1-2$

1.3 CONTAMINATION CONTROL IMPROVEMENT PROJECT $\ldots \ldots \ldots \ldots \ldots \ldots$

1.3.1 Airborne Radioactivity Areas . . . . . . . . . . . . . . . 1-4

1.3.2 Indoor and Outdoor Contamination Area . . . . . . . . . . 1-5

1.3.3 CA Reduction - Indoor and Outdoor Areas ............. 1-7

1.4 ALARA PROGRAM LESSONS LEARNED THROUGH POST ALARA REVIEWS . $1-8$

1.5 ALARA TRACKING AND MANAGEMENT SYSTEM $\ldots \ldots \ldots \ldots \ldots \ldots \ldots \ldots$

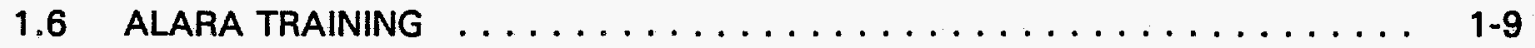

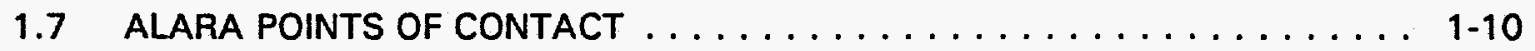

2.0 INDUSTRIAL SAFETY AND HYGIENE $\ldots \ldots \ldots \ldots \ldots \ldots \ldots \ldots \ldots \ldots$

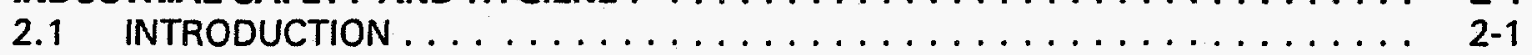

2.2 ONGOING INDUSTRIAL SAFETY AND HEALTH INITIATIVES $\ldots \ldots \ldots \ldots . . .2-2$

2.2.1 Voluntary Protection Program (VPP) . . . . . . . . . . . . . . 2 2-2

2.2.1.1 Management Leadership . . . . . . . . . . . . 2-3

2.2.1.2 Employee Involvement . . . . . . . . . . . . . 2-3

2.2.1.3 Hazard Prevention and Control . . . . . . . . . . . 2-4

2.2.1.4 Safety and Health Training . . . . . . . . . . . . . . 2-4

2.2 .2 Safety Meeting Improvement ................ $2-5$

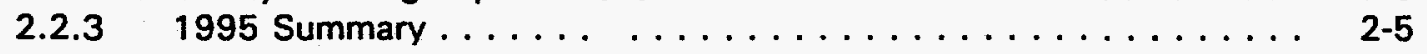

2.2.3.1 First Quarter . . . . . . . . . . . . . . . 2-5

2.2.3.2 Second Quarter. . . . . . . . . . . . . . . . 2-5

2.2.3.3 Third Quarter . . . . . . . . . . . . . . . 2-6

2.2.3.5 Fourth Quarter. . . . . . . . . . . . . . 2-6

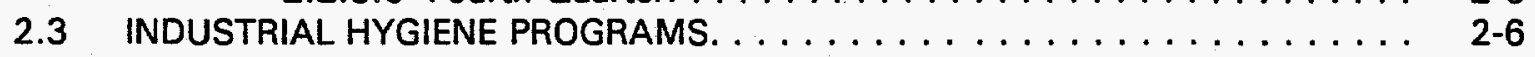

2.3.1 Industrial Hygiene Workscope Change $\ldots \ldots \ldots \ldots \ldots \ldots . \ldots \ldots$ 2-6

2.3.1.1 Centralized Industrial Hygiene Equipment Laboratory . . . . 2-6

2.3.1.2 Industrial Hygiene Exposure Monitoring Records System .. 2-6

2.3.1.3 Exposure Assessment Activities ... . . . . . . . . 2-7

2.3.1.4 Respiratory Protection. . . . . . . . . . . . . . . 2-7

2.3.2 WHC-CM-1-11, Industrial Hygiene Manual . . . . . . . . . . 2-7

2.3.3 Safety Department Administrative Manual . . . . . . . . . . . 2-7

2.4 TOPICS OF INTEREST . . . . . . . . . . . . . . . . . . . . 2-8

2.4.1 Hanford Site Safety and Health Exposition "Expo '96" . . . . . . 2 2-8

2.4.2 Safety Resource Center . . . . . . . . . . . . . . . . . . . 2-8

2.5 COMPANY-WIDE AND DEPARTMENT-LEVEL TRENDING

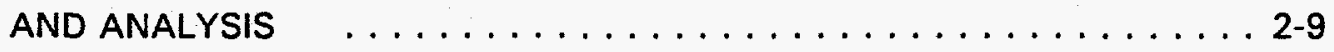

2.5.1 Occupational Injury/lilness Incidence Rates ........... 2-9

2.5.2 Lost/Restricted Workday Case Incidence Rates ... . . . . . . . . 2-10

2.5.3 Lost/Restricted Workday Incidence Rates . . . . . . . . . . . 2-12

2.5.4 Total Recordable Case Incidence Rates .............. . . 2-13

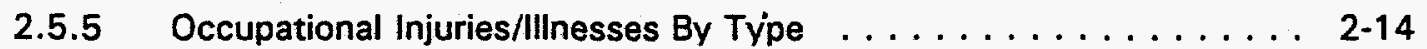

2.5.6 Occupational Injuries/lllnesses By Body Group Injured . . . . . . . . . 2 2-15

2.5.7 Occupational Injuries/llinesses By Cause . . . . . . . . . . . . 2-16

2.5.8 Occupational Injuries/lllnesses By Job Type . . . . . . . . . . . 2-17 
2.5.9 Occupational Injuries/Illnesses By Facility . . . . . . . . . . . . . 2-18

2.5.10 Human Resources. . . . . . . . . . . . . . . . . . 2-19

2.5.11 Transition Projects. . . . . . . . . . . . . . . . . 2-20

2.5.12 Spent Nuclear Fuel Project . . . . . . . . . . . . . . . 2-21

2.5.13 Emergency, Safety, Quality Services ................ 2-22

2.5.14 Chief Financial Office ................... 2-23

2.5.15 BCS Richland, Incorporated . . . . . . . . . . . . . 2-24

2.5.16 Tank Waste Remediation Systems . . . . . . . . . . . . . 2-25

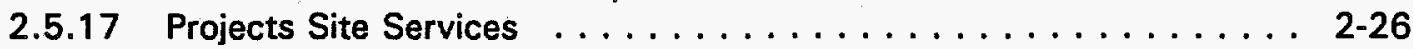

2.5.18 Solid Waste Disposal . . . . . . . . . . . . . . 2-27

2.5.19 ICF Kaiser Hanford Company ... . . . . . . . . . . . . . . 2-28

2.5.20 Recordable Government Motor Vehicle Accidents . . . . . . . . . 2-29

3.0 RADIOLOGICAL SAFETY $\ldots \ldots \ldots \ldots \ldots \ldots \ldots \ldots \ldots \ldots \ldots \ldots \ldots$

3.1 RADIOLOGICAL CONTROL PROGRAM PERFORMANCE $\ldots \ldots \ldots \ldots \ldots$ 3-1

3.1.1 Key Performance Trends. . . . . . . . . . . . . . .

3.1.2 Program Accomplishments .................. 3 3-1

3.2 EXTERNAL DOSIMETRY . . . . . . . . . . . . . . . . 3-3

3.2.1 Occupational Collective Dose ................. 3-3

3.2.1.1 Cumulative Annual Occupational Collective Dose ..... . 3-3

3.2.1.2 Individual Radiation Dose ... . . . . . . . . . . . . . . 3-3

3.2.2 High Whole Body Dose Evaluation ... . . . . . . . . . . 3-4

3.2.3 High Neutron Dose . . . . . . . . . . . . . . . . . . . 3-5

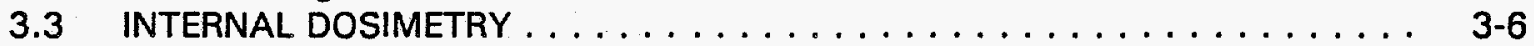

3.3.1 Internal Depositions . . . . . . . . . . . . . . . . . 3-6

3.3.2 Internal Dose Incident Follow-Up . . . . . . . . . . . . . 3-6

3.3.3 Direct and (in vivo) Indirect (in vitro) Measurements . . . . . . . . . 3- 3-6

3.4 SKIN AND CLOTHING CONTAMINATIONS . . . . . . . . . . . . . 3-9

3.4.1 Cumulative CY 1995 Skin Contaminations and Clothing Contaminations 3-9

3.4.2 Facility Comparisons for $\mathrm{CY} 1994$ and $\mathrm{CY} 1995 \ldots \ldots \ldots$. . . . 3-10

3.4.3 Detection of Personal Contaminations .............. 3-10

3.4.4 Significant Skin Contaminations ............... 3-11

3.4.5 Facial Contaminations ................... 3-

$11 \quad 3.4 .6 \quad$ Skin and Clothing Contamination Report Review . . . . . . . . . 3-12

3.4.7 Historical Skin Contaminations .................

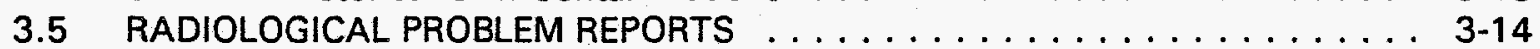

3.5.1 Radiological Problem Reports Issued . . . . . . . . . . . . . . 3-14

3.5.1.1 Factors Influencing the Number of RPRs Written . . . . . . 3-15

$3.5 .2 \quad$ RPR Trends . . . . . . . . . . . . . . . . . . 3-16

3.5.2.1 RPRs by Priority Planning Grid . . . . . . . . . 3-16

3.5.2.2 RPRs by Type and Cause .............. 3-16

3.5.2.3 Contamination Events . . . . . . . . . . . 3-17

3.6 DOSIMETRY .......................... 3-18

REFERENCES $\ldots \ldots \ldots \ldots \ldots \ldots \ldots \ldots \ldots \ldots \ldots \ldots \ldots \ldots \ldots \ldots \ldots$

APPENDICES $\ldots \ldots \ldots \ldots \ldots \ldots \ldots \ldots \ldots \ldots \ldots \ldots \ldots \ldots \ldots \ldots \ldots$ A-1

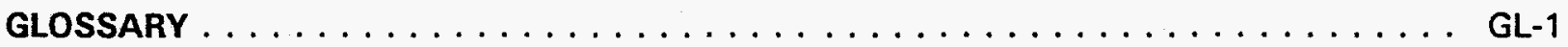


WHC-SP-0564-40

This page intentionally left blank. 


\section{LIST OF FIGURES}

1-3-1 Airborne Radioactivity Areas $\ldots \ldots \ldots \ldots \ldots \ldots \ldots \ldots \ldots \ldots \ldots \ldots$

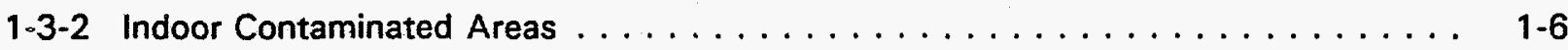

1-3-3 Outdoor Contaminated Areas . . . . . . . . . . . . . . . . 1-6

1-3-4 Contaminated Area Reduction by Facility Group - FY $1995 \ldots \ldots$. . . . . . . . . 1-7

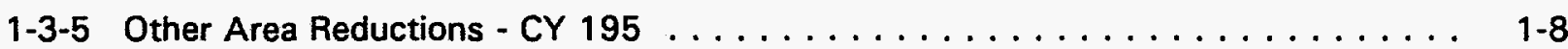

2-1 WHC Lost/Restricted Workday Case Incidence Rate . . . . . . . . . . . . 2-11

2-2 WHC Lost/Restricted Workday Case Monthly Incidence Rates CY 1990-CYTD 1995 - 3 Standard Deviations . . . . . . . . . . . . . . . . 2-11

2-3 WHC Lost/Restricted Workday Incidence Rates . . . . . . . . . . . . . . . . 2-12

2-4 WHC Lost/Restricted Workday Monthly Incidence Rates

2-5 WHC Total Recordable Case Incidence Rate $\ldots \ldots \ldots \ldots \ldots \ldots$. . . . . . . . . 2-13

2-6 WHC Total Recordable Case Monthly Incidence Rates CY 1990-CYTD 1995 - 3 Standard Deviations . . . . . . . . . . . . . . . . . 2-13

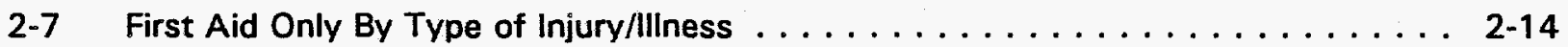

2-8 Total Recordable Injuries/lliness By Type . . . . . . . . . . . . . . . . . 2-14

2-9 Lost/Restricted Workday Cases By Type of Injury/lliness . . . . . . . . . . . . . 2-14

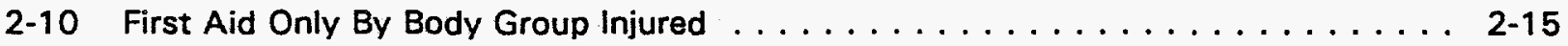

2-11 Total Recordable Injuries/lllnesses By Body Group Injured . . . . . . . . . . . 2-15

2-12 Lost/Restricted Workday Cases By Body Group Injured . . . . . . . . . . . . . 2-15

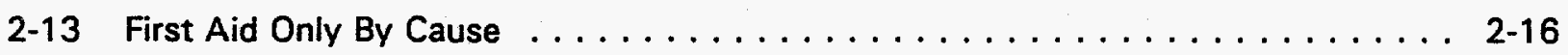

2-14 Total Recordable Injuries/llinesses By Cause $\ldots \ldots \ldots \ldots \ldots \ldots \ldots$ 2-16

2-15 Lost/Restricted Workday Cases By Cause . . . . . . . . . . . . . . . . . . 2-16

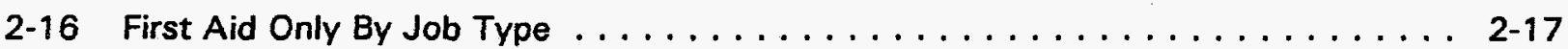

2-17 Total Recordable Injuries/llinesses By Job Type . . . . . . . . . . . . . . . 2-17

2-18 Lost/Restricted Workday Cases By Job Type . . . . . . . . . . . . . . . . . 2-17

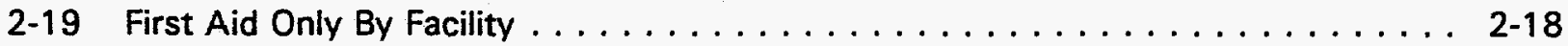

2-20 Total Recordable Injuries/llinesses By Facility . . . . . . . . . . . . . . 2-18

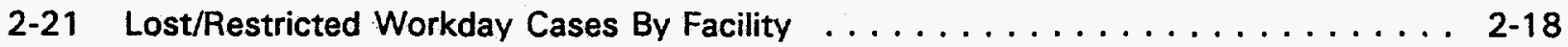

2-22 ICF KH Lost/Restricted Workday Case Rates . . . . . . . . . . . . . . . . . 2-28

2-23 ICF KH Lost/Restricted Workday Incidence Rates . . . . . . . . . . . . . . . . . . 2-28

3-2-1 Monthly, Quarterly and Annual Exchange Dosimeter Results . . . . . . . . . . . 3-3

3-2-2 Monthly Badged Employee Average Cumulative Radiation Dose . . . . . . . . . 3-4

3-2-3 Whole Body Dose Distribution - Cumulative . . . . . . . . . . . . . . . . . 3-4

3-2-4 Highest Neutron Dose . . . . . . . . . . . . . . . . . . . . . . . . . . 3-5 


\section{LIST OF FIGURES (Continued)}

3-3-1 Indirect (In Vitro) Measurements $\ldots \ldots \ldots \ldots \ldots \ldots \ldots \ldots \ldots \ldots$

3-3-2 Direct (In Vivo) Measurements $\ldots \ldots \ldots \ldots \ldots \ldots \ldots \ldots \ldots \ldots \ldots$

3-4-1 1995 Skin and Clothing Contaminations $\ldots \ldots \ldots \ldots \ldots \ldots \ldots$

3-4-2 Skin and Clothing Contamination Comparison by Facility . . . . . . . . . . 3-10

3-4-3 Facial Contaminations ........................ 3-11

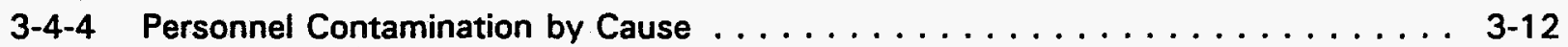

3-4-5 Twelve-Year Recordable Skin contamination Comparison . . . . . . . . . . 3-13

3-4-6 Skin Contaminations Occurring in WHC-Managed Facilities/Areas . . . . . . . . . 3-13

3-5-1 Cumulative Radiological Problem Reports Issued . . . . . . . . . . . . . . 3-14

3-5-2 Facilities Issued RPRs -1993 through $1995 \ldots \ldots \ldots \ldots \ldots \ldots$. . . . . . . 15

3-5-3 RPRs by Type/Cause. . . . . . . . . . . . . . . . . . 3-17

3-6-1 Dose Assessments Performed for Lost or Damaged Dosimeters . . . . . . . . . 3-18 


\section{LIST OF TABLES}

1-3-1 Airborne Radioactivity Areas by Facility Group . . . . . . . . . . . . . . . 1-4

1-3-2 Indoor contamination Areas and High-Contamination Areas $\ldots \ldots \ldots$ 1-6

1-3-3 Outdoor Contamination Areas $\ldots \ldots \ldots \ldots \ldots \ldots \ldots \ldots \ldots \ldots \ldots \ldots \ldots$

1-7-1 ALARA Council Members $\ldots \ldots \ldots \ldots \ldots \ldots \ldots \ldots \ldots \ldots \ldots \ldots$

2-1 Occupational Injury/liness Case Rates Comparison $\ldots \ldots \ldots \ldots \ldots$ 2-2

2-2 WHC Occupational Injury/lliness Statistics Comparison $\ldots \ldots \ldots \ldots \ldots$

2-3 Human Resources Occupational Injury/lliness Statistics Comparison $\ldots \ldots \ldots$. . . 2-19

2-4 Human Resources Occupational Injury/lliness by Type $\ldots \ldots \ldots \ldots \ldots \ldots$. . . . . . . .

2-5 Transition Projects - Occupational Injury/lliness Statistics Comparison $\ldots \ldots$. . 2-20

2-6 Transition Projects - Occupational Injury/lliness by Type . . . . . . . . . . . . 2-20

2-7 Spent Nuclear Fuel - Occupational Injury/llIness Statistics Comparison . . . . . . . 2-21

2-8 Spent Nuclear Fuel - Occupational Injury/lliness by Type . . . . . . . . . . 2-21

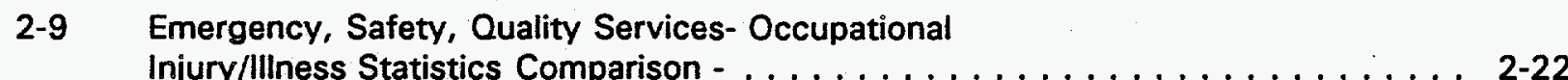

2-10 Emergency, Safety, Quality Services - Occupational Injury/lilness by Type . . . . 2-22

2-11 Chief Financial Office - Occupational Injury/lilness Statistics Comparison . . . . 2-23

2-12 Chief Financial Office - Occupational Injury/lliness by Type . . . . . . . . . 2-23

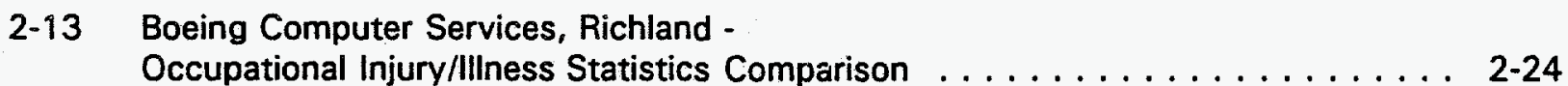

2-14 Boeing Computer Services, Richland - Occupational Injury/lliness by Type . . . . 2-24

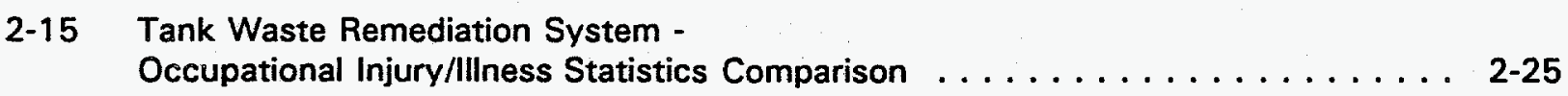

2-16 Tank Waste Remediation System - Occupational Injury/lilness . . . . . . . . . 2-25

2-17 Projects Site Services - Occupational Injury/lllness Statistics Comparison . . . . . 2-26

2-18 Projects Site Services - Occupational Injury/lliness by Type . . . . . . . . . 2-26

2-19 Solid Waste Disposal - Occupational Injury/lliness Statistics Comparison . . . . . 2-27

2-20 Solid Waste Disposal - Occupational Injury/lliness by Type . . . . . . . . . . . . . 2-27

2-21 Recordable Vehicle Accidents by Organization . . . . . . . . . . . . . . 2-29

2-22 Recordable Vehicle Accidents by Cause of Accident . . . . . . . . . . . . 2-29

3-2-1 Highest Whole Body Dose Employees . . . . . . . . . . . . . . . . 3-5 


\subsection{ALARA}

"As Low As Reasonably Achievable" (ALARA) is an approach to radiation and hazard protection that manages and controls radiological exposures (both individual and collective) to the work force and the general public to levels as low as reasonably achievable. In addition to dose limitation, one of the basic principles of radiation protection is that doses must be kept ALARA, taking into account social, technical, economic, practical, and public policy considerations. This is the now-famous ALARA, or optimization of radiation protection, principle. ALARA should also be defined as choosing the best course of action under some given circumstances.

It should be clarified that ALARA is not a dose limit, but a process with the objective of attaining and maintaining exposures as far below the applicable limits as is reasonably achievable. The purpose of this section is to address how this process is being accomplished within the Westinghouse Hanford Company (WHC) ALARA/Contamination Control Improvement Project (CCIP) Program.

The ALARA principle began to be used in radiation protection after the effects of radiation were discovered. In the early days, the theory was that there existed a threshold for radiation effects, and therefore good protection meant keeping exposures below that threshold. This theory was complicated by the discovery of the "stochastic" effects of radiation - those effects that appeared below the threshold for acute effects. It still is not clear whether these effects are valid for very small doses; consequently, practical radiation protection assumes that these effects apply for all exposures down to zero and attempts to maintain exposure to radiation ALARA.

In 1993, the U.S. Department of Energy (DOE) published implementation guidance for radiation protection programs in Title 10, Code of Federal Regulations, Part 835 (10 CFR 835). The ALARA Program is required to be established by 10 CFR 835, Sub-part B, "Radiation Protection Programs," Article 835.101 (c), which states: "The content of each RPP [Radiological Protection Program] shall be commensurate with the nature of the activities performed and shall include formal plans and measures for applying the ALARA process to occupational exposure."

Management's approach towards radiation work has a great influence on the degree of radiation exposure in the workplace. History has shown that effective dose reduction needs firm management involvement and support. The ALARA principle, applied through all levels of management and workforce and in all important works, is a useful tool in this respect.

The focus of the ALARA section of this publication has been expanded to provide information not only of the events that occurred during the fourth quarter of calendar year (CY) 1995, but to provide an overview of the major achievements of the ALARA/CCIP Program during the entire year.

\subsection{WHC ALARA GOALS}

In an attempt to provide facility/organizational ALARA committees with another tool in the preparation of their ALARA goals, the ALARA performance goal process was modified from a CY cycle to a fiscal year (FY) cycle. Due to difficulties in managing personnel exposure on a FY basis and guidance provided in letter 9503579 by the DOE, Richland Operations Office (RL), dated 
WHC-SP-0564-40

July 24, 1995, the FY 1995 ALARA performance goals were revised and have been reported as CY 1995 goals.

During CY 1995, an increased amount of attention was placed on the ALARA performance goal process by facility ALARA committees, the WHC ALARA Council, the WHC ALARA/CCIP Program Office, and RL. Each ALARA committee revised their ALARA goals from a FY to a CY reporting cycle. This aligned personnel exposure goals with Dosimetry reporting and increased the "value added" of the exposure goals promoted by ALARA committees.

Site-wide and facility-specific ALARA goals will continue to be planned concurrent with the budget planning process. This should ensure that funding for ALARA projects and protective measures are considered and allocated as necessary.

During the FY 1996 milestone planning process, significant changes were made to the milestones that status the WHC ALARA Program. These changes include adding a written quarterly report from WHC to RL statusing the radiological performance indicators and the ALARA goals.

\subsubsection{Sitewide ALARA Performance Goals}

During CY 1995, all 15 WHC sitewide ALARA performance goals were completed on or ahead of schedule. One of the completed goals related to the WHC ALARA Committees revising or developing ALARA plans/procedures to comply with the requirements of 10 CFR 835. Each of the ALARA committees have completed their ALARA plans/procedures in compliance with 10 CFR 835 requirements. For detailed information relating to the status of CY 1995 WHC sitewide ALARA performance goals, refer to Appendix A-1 of this report.

The initial CY 1996 WHC sitewide ALARA performance goals were provided to RL in November 1995 and are contained in Appendix A-2.

\subsubsection{Facility/Organization ALARA Goal Performance}

Progress on the implementation of the facility/organization ALARA program at WHC is evidenced in part by the development and achievement of ALARA performance goals by the facility/organization ALARA committees. The CY 1995 facility-specific goals were established to effectively implement exposure reduction activities, provide an incentive to implement ALARA, and as a method to measure achievements and management commitment to ALARA programs. However, the ALARA goals are not the only means utilized to measure the effectiveness of the facilities ALARA program. A synopsis of some of the field implementation of ALARA principles and radiological engineered devices can be found in Section 1.2 of this report.

\subsection{ALARA/CONTAMINATION CONTROL IMPROVEMENT PROJECT (CCIP) PROGRAM IMPLEMENTATION, PROGRESS, AND ACHIEVEMENTS}

It is important to acknowledge contributions and accomplishments of the WHC ALARA/CCIP Program by communicating the progress and achievements made in the implementation of the program. The following is a list of some of the contributions and accomplishments during CY 1995.

- The WHC ALARA Occupational Program, WHC-IP-1043, was published and replaces WHC-CM4-11. The publication of this document met 14 RPP, WHC-SP-1145, commitments and resolved 
the commitment from internal audit, SAF-93-0002-SCA-RP-02A. The WHC-IP-1043 provides guidance for implementing the ALARA process in compliance with 10 CFR 835 requirements.

- All 13 of the facility ALARA committees participated in the revision of the plans/procedures controlling their ALARA program. The rewrites were accomplished to meet the requirements identified in 10 CFR 835 and committed to the RPP.

- The ALARA/CCIP Program Office performed an ALARA review of the proposed Fuel Canister Building being planned for the storage of fuel scheduled for removal from $\mathrm{K}$ Basins.

Recommendations from this review are being incorporated into the building's design. Indications are that the suggestions from this review will allow this building to be built within budget and under previous cost estimates.

- Milestones RAD-95-010 and 013, to conduct quarterly interface meetings with representatives from RL, were all completed on or ahead of schedule. These reviews included statusing of: the ALARA sitewide and facility and organization-specific ALARA goals, radiological/contaminated area reduction, discussion of RL expectations of the WHC ALARA program, and the implementation of practical ALARA applications.

- In an effort to increase Hanford employees' ALARA awareness, the ALARA/CCIP Program Office submitted several ALARA-related articles to the Hanford Reach newspaper during CY 1995. One of the articles explained the difference between personnel radiological exposure levels and limits. These types of articles have prompted Hanford employees to contact the ALARA/CCIP Program Office, seeking additional information or clarification of ALARA-related topics.

- The WHC ALARA/CCIP Program Office sponsored several vendor demonstrations during CY 1995 including: a light-aided decontamination system, heat and cold stress reduction clothing by Norco, a newly designed contamination fixative by Timberline Enterprises, and an electronic dosimetry system by MGP Instruments.

- The WHC ALARA/CCIP Program was a major participant at the Hanford Health and Safety Exposition (Expo), held in April 1995. With over 5,500 Hanford employees and their family members in attendance, Expo '95 afforded a unique opportunity to share the philosophy and advantages of ALARA with a wide scope of the community.

Due to the success of Expo '95, the ALARA program will utilize the upcoming Expo '96 to further the ALARA awareness efforts of Hanford families.

- Representatives of the WHC ALARA/CCIP Program Office conducted over 30 training sessions discussing the completion of ALARA Management Worksheet and Post ALARA Review. As part of these training sessions, the ALARA/CCIP Program Office demonstrated different techniques used to reduce exposure and limit the spread of contamination. In addition, emphasis was placed on the value of using the "Search Hanford Accessible Records Electronically" (SHARE) database and involving radiological control personnel early in the planning process.

Additional information regarding these accomplishments or other ALARA Program accomplishments may be obtained by reviewing previous issues of this publication, or by contacting the WHC ALARA/CCIP Program Office (376-9035/376-0818). 


\subsection{CONTAMINATION CONTROL IMPROVEMENT PROJECT}

The CCIP encourages reduction of radioactive surface contamination in operating areas and the environment of the Hanford Site. Reducing the number of contaminated areas and the severity of contamination will reduce the risk of skin contaminations and internal depositions, minimize personnel exposure, increase site productivity, and improve protection of the environment.

Due to the new posting definitions found in the Hanford Site Radiological Control Manual (HSRCM), the CCIP database was reconfigured during the fourth quarter of 1994. Currently, for CCIP purposes, the postings are grouped as follows: Airborne radioactivity areas (ARA); total contamination areas (CA) which include high $\mathrm{CA}, \mathrm{CA}$ and soil CA; total radiation areas (RA) which include very high RA, high RA, and RA; and other radiological areas which includes radiological buffer area, fixed contamination area, radioactive material area (RMA), and underground radioactive materials. The result of these changes is there is no continuity between the fourth quarter and previous ones. Therefore, the only comparison in this section will be between the current quarter (fourth of CY 1995) and the previous four.

The CCIP tracks CAs, as well as the categorization of areas controlled for radiological reasons and the quantification of said areas. It also tracks, separately from CAs, ARAs. The project identifies, tracks, and encourages the reduction of radioactive surface contamination and the number of other radiologically controlled areas. It addresses ARAs in indoor areas and CAs and other areas in indoor and outdoor operating areas.

\subsubsection{Airborne Radioactivity Areas}

Airborne Radioactivity Areas are tracked separately from CAs because of the inherent increased risk to the occupational worker. Generally, ARAs are not as easy to decrease as surface contaminated areas (SCA) because they are related to the process and are engineered areas. They are decreased as the underlying process is changed or discontinued and the area is decontaminated (Figure 1-3-1). There were no reductions in ARAs during this quarter.

The number (as well as the total size) of ARAs established by facility group for the fourth quarter of 1995 is listed in Table 1-3-1. Please note that the number of ARAs may be arbitrary, in that one facility may elect to group all their ARAs together (for CCIP reporting purposes), while another may report each individual ARA separately.

1-3-1. Airborne Radioactivity Areas by Facility Group

\begin{tabular}{|l|c|c|c||l|c|c|c|}
\hline \multicolumn{1}{|c|}{ Facility } & $\begin{array}{c}\text { No. of } \\
\text { ARAs }\end{array}$ & $\begin{array}{c}\text { ARAs in } \\
\text { Sq. Meters }\end{array}$ & $\begin{array}{c}\text { ARAs in } \\
\text { Sq. Feet }\end{array}$ & Facility & $\begin{array}{c}\text { No. of } \\
\text { ARAs }\end{array}$ & $\begin{array}{c}\text { ARAs in } \\
\text { Sq. } \\
\text { Meters }\end{array}$ & $\begin{array}{c}\text { ARAs in } \\
\text { Sq. Feet }\end{array}$ \\
\hline \hline B Plant & 14 & 4,472 & 48,134 & Solid Waste & 1 & 1,272 & 13,689 \\
\hline $\begin{array}{l}\text { Fast Flux Test } \\
\text { Facility (FFTF) }\end{array}$ & 1 & 42 & 450 & T Plant & 7 & 3,957 & 42,595 \\
\hline $\begin{array}{l}\text { Analytical } \\
\text { Laboratories }\end{array}$ & 6 & 163 & 1,758 & Tank Farms & 11 & 612 & 6,586 \\
\hline $\begin{array}{l}\text { Plutonium Finishing } \\
\text { Plant (PFP) }\end{array}$ & 6 & 1,241 & 13,361 & $\begin{array}{l}\text { Liquid Effluent } \\
\text { Services }\end{array}$ & 2 & 136 & 1,460 \\
\hline PUREX & 20 & 4,756 & 51,192 & Total & 68 & 16,651 & 179,225 \\
\hline
\end{tabular}


Figure 1-3-1. Airborne Radioactivity Areas

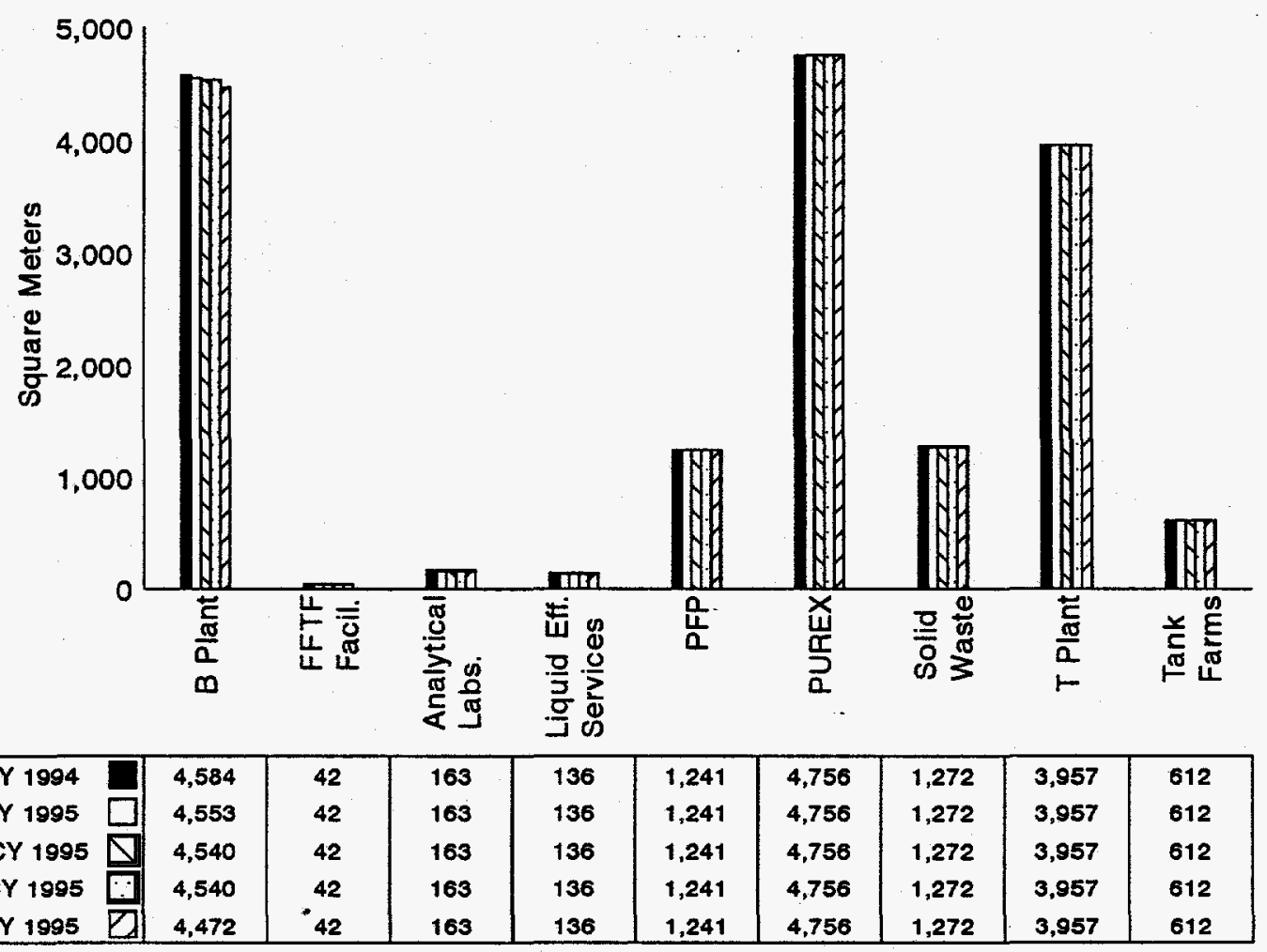

\subsubsection{Indoor and Outdoor CA}

Most facilities have been reducing the amount of posted CAs indoor. During the fourth quarter of 1995 (October - December), there were reported reductions in total indoor CA of nearly 273 square meters (2,940 square feet) and in outdoor CA of nearly 3.7 hectares $(9.2$ acres). There were no increases in total CA reported during this period. 1-3-3).

- Overall, the amount of indoor and outdoor "total" CA has been decreasing (Figures 1-3-2 and 
Figure 1-3-2. Indoor Contaminated Areas

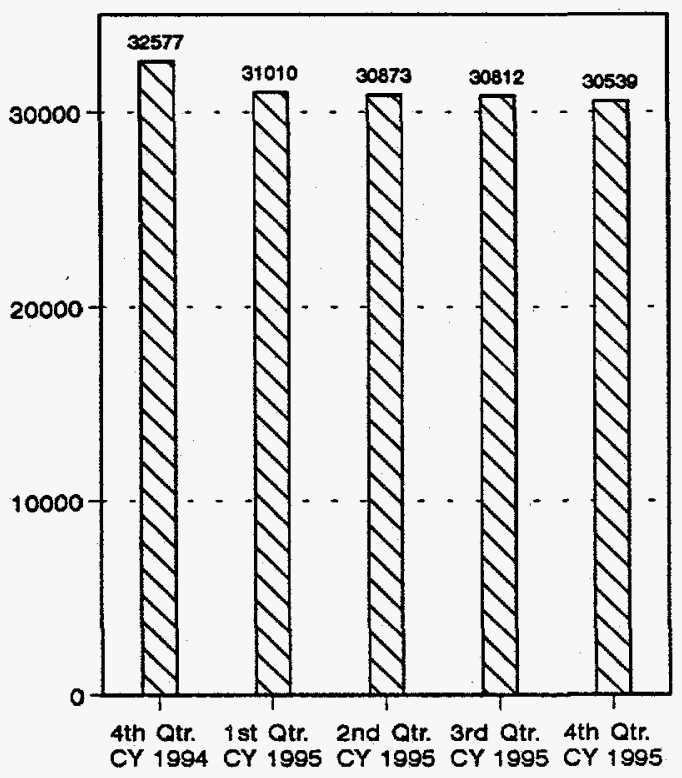

Figure 1-3-3. Outdoor Contaminated Areas

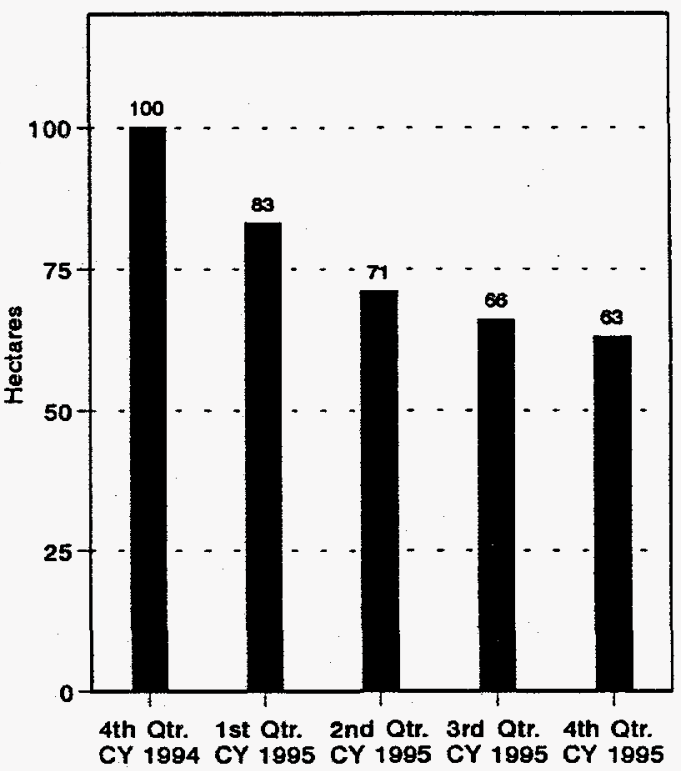

The number (as well as the total size) of high contamination areas (HCA) and CAs indoors, as established by facility group for the fourth quarter of CY 1995, is listed in Table 1-3-2 and for outdoor areas in Table 1-3-3. Please note that the number of HCAs and CAs may be arbitrary, in that one facility may elect to group all their CAs together (for CCIP reporting purposes), while another may report each individual CA separately.

Table 1-3-2 Indoor Contamination Areas and High-Contamination Areas

\begin{tabular}{|l|r|r|r|r|r|r|}
\hline \multicolumn{1}{|c|}{ Indoor Areas } & $\begin{array}{c}\text { No. } \\
\text { HCAs }\end{array}$ & $\begin{array}{l}\text { Area in } \\
\text { Meters }\end{array}$ & $\begin{array}{c}\text { Area in } \\
\text { Square } \\
\text { Feet }\end{array}$ & $\begin{array}{l}\text { No. } \\
\text { CAs }\end{array}$ & $\begin{array}{l}\text { Area in } \\
\text { Meters }\end{array}$ & $\begin{array}{c}\text { Area in } \\
\text { Square Feet }\end{array}$ \\
\hline \hline 300 Area Facilities & 0 & 0 & 0 & 18 & 2,044 & 21,999 \\
\hline B Plant & 2 & 3,702 & 39,850 & 35 & 1,283 & 13,813 \\
\hline FFTF Facilities & 1 & 42 & 450 & 3 & 230 & 2,476 \\
\hline K Basins & 0 & 0 & 0 & 5 & 2,925 & 31,484 \\
\hline Analytical Laboratories & 4 & 154 & 1,654 & 49 & 2,114 & 22,751 \\
\hline Liquid Effluent Services & 2 & 136 & 1,460 & 4 & 538 & 5,788 \\
\hline PFP & 4 & 501 & 5,391 & 11 & 3,901 & 41,995 \\
\hline PUREX & 11 & 4,145 & 44,615 & 37 & 3,896 & 41,934 \\
\hline Support Services & 0 & 0 & 0 & 6 & 275 & 2,964 \\
\hline T Plant & 4 & 2,624 & 28,246 & 11 & 684 & 7,361 \\
\hline Tank Farms & 4 & 113 & 1,218 & 13 & 1,233 & 13,271 \\
\hline \hline Total & 32 & 11,416 & 122,884 & 192 & 19,123 & 205,836 \\
\hline
\end{tabular}


Table 1-3-3. Outdoor Contamination Areas

\begin{tabular}{|l|r|r|r||l|r|r|r|}
\hline Outdoor Areas & $\begin{array}{c}\text { No. } \\
\text { CAs }\end{array}$ & $\begin{array}{c}\text { Area in } \\
\text { Hectares }\end{array}$ & $\begin{array}{c}\text { Area in } \\
\text { Acres }\end{array}$ & Outdoor Areas & $\begin{array}{c}\text { No. } \\
\text { CAs }\end{array}$ & $\begin{array}{c}\text { Area in } \\
\text { Hectares }\end{array}$ & $\begin{array}{c}\text { Area in } \\
\text { Acres }\end{array}$ \\
\hline \hline 300 Area Facil. & 1 & 0.0 & 0.1 & Solid Waste & 4 & 7.0 & 17.2 \\
\hline B Plant & 10 & 4.5 & 11.1 & Support Services & 5 & 0.2 & 0.4 \\
\hline Environmental & 5 & 1.2 & 3.1 & Surplus Facilities & 1 & 0.1 & 0.2 \\
\hline K Basins & 2 & 0.3 & 0.7 & T Plant & 9 & 0.9 & 2.3 \\
\hline PUREX & 11 & 6.8 & 16.8 & Tank Farms & 39 & 40.8 & 100.8 \\
\hline \hline
\end{tabular}

\subsubsection{CA Reduction - Indoor and Outdoor Areas}

The CCIP tracks reduction efforts separately from the overall total posted areas and tracks and trends the total area reduced by facility on a quarterly basis. During the fourth quarter of 1995 , a total of approximately 37,400 square meters (403,400 square feet) was released from CA posting. Specific reductions by facility per quarter (in square meters) are found in Figure 1-3-4.

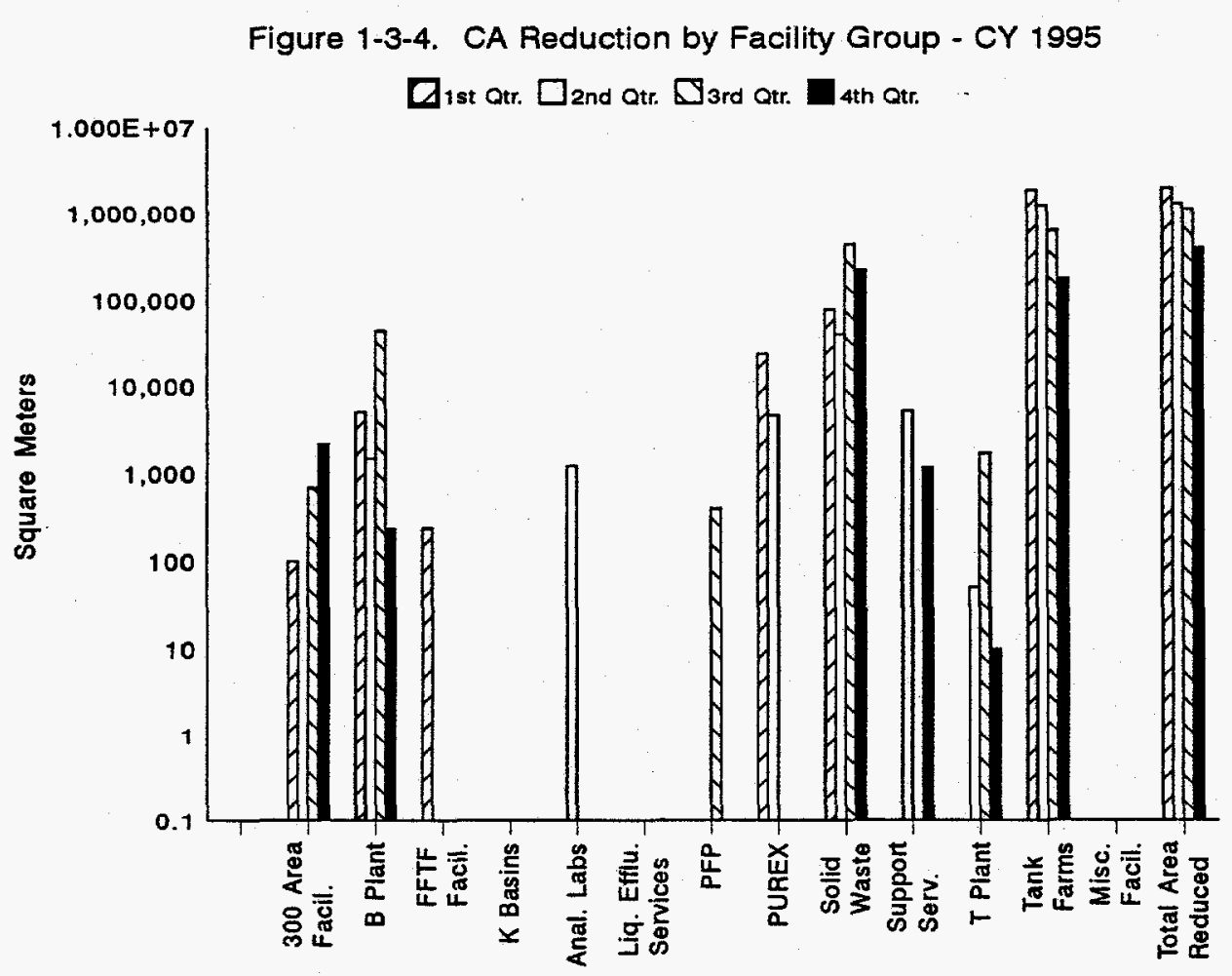

The CCIP also tracks reductions in areas posted less than CA (e.g. RAs, RMAs, etc.). During the same time period, a total of approximately 33,800 square meters $(364,000$ square feet) of "other" area was down-posted. Specific reductions by facility per quarter (in square meters) are found in Figure 1-3-5. 
Figure 1-3-5. Other Area Reductions - CY 1995

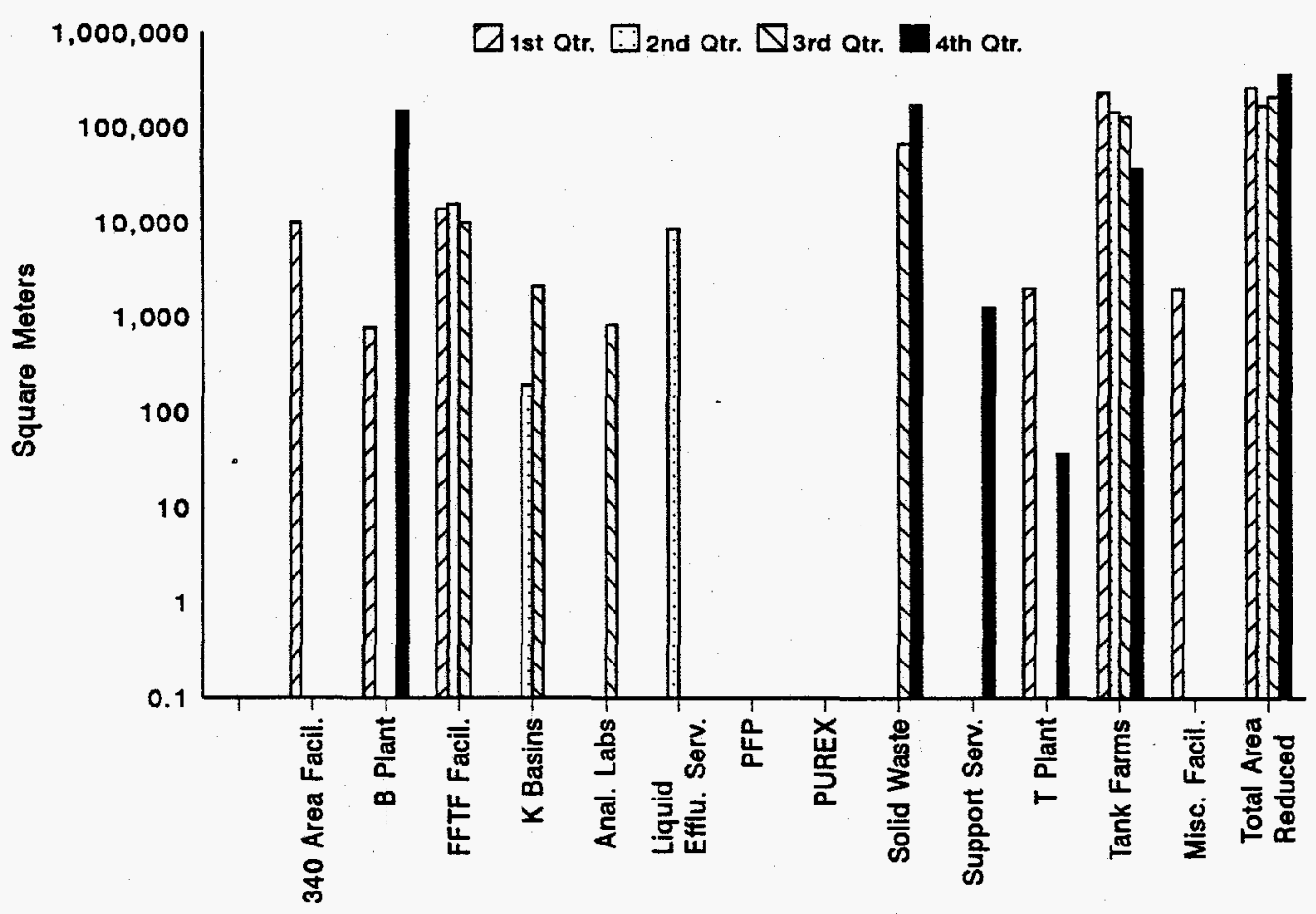

\subsection{ALARA PROGRAM LESSONS LEARNED THROUGH POST ALARA REVIEWS}

The SHARE database was designed to provide an intelligent information-retrieval system that allows users to create query topics to meet their individual needs. The WHC ALARA Program currently utilizes this database to redeploy ALARA protective measures, lessons learned, and corrective actions obtained from radiological work performed onsite. The SHARE database is now available to Hanford personnel involved in the process of designing, performing, and/or managing work projects. It makes completed copies of Post ALARA Reviews (PAR) available electronically for review, retrieval, and use by planners, persons-in-charge (PIC), engineers, ALARA personnel, etc., in the creation of work packages and in performing prejob briefings.

Previously, there has been concern regarding the time delay for completing the PAR process after a task is complete. With the revisions to the WHC Occupational ALARA Program, changes were made to the "trigger levels" used for initiating the PAR process. The new "trigger levels" are identified in the HSRCM, Article 352. These new levels have provided more "value added" to the PAR process, require fewer PARs to be conducted, and allow for time and effort to be dedicated to the debriefing of radiological work.

The PAR process is a vital tool in helping to prevent complacency, reduce personnel exposure, monitor job performance, and in identifying lessons learned and corrective actions for incorporation into similar job packages. The lessons learned help to evaluate the effectiveness of the exposure controls/work practices that were implemented and reduce future problems by applying these experiences. Indications demonstrate that the acceptance and ownership of the PAR process is being significantly enhanced. The SHARE database has proven to be an effective method of transferring lessons learned and corrective actions between facilities. 
Detailed information on completed PARs may be obtained by accessing the SHARE database, reviewing previous issues of this publication, or contacting the WHC ALARA/CCIP Program Office.

\subsection{ALARA TRACKING AND MANAGEMENT SYSTEM}

In order to identify, track, and manage personnel exposure within the responsible facility/organization, the ALARA Tracking and Management System (ATAMS) was developed. The system assists the ALARA/CCIP Program Office and ALARA Committee chairpersons in tracking the exposure levels of personnel under their jurisdiction, and the investigation of any anomaly. The ATAMS has further served to heighten exposure awareness levels of personnel and, with each investigation performed, it encourages management to consider the ALARA approach to exposure. The system selects individual and organizational anomalies identified within the following set of parameters and criteria:

- The top one percent of the monthly/quarterly thermoluminescent dosimeters (TLD) processed;

- Extrapolated exposures through year end that will exceed a WHC worker's administrative guideline level;

- Individuals with significantly higher whole body dose than peers within their craft;

- Individuals identified as having high finger ring doses versus deep dose;

- Unusual TLD results identified during this processing period (i.e., shallow less than deep exposure);

- Individuals identified as having high neutron dose.

Investigative reports are required to provide an explanation for the anomaly. The investigative reports include a description of the ALARA protective measures that were used, the job work scope being performed, and any resolutions to reduce the repeat of similar exposures.

Investigations of anomalies completed during the fourth quarter revealed a concerted effort to maintain radiation exposure in the workplace ALARA. Certain trends may be identified with a direct relationship to areas where exposure-producing operations and activities are occurring within WHCmanaged facilities. Although anomalies were noted, they resulted in exposures well below the administrative guidelines established by WHC.

Further information on ATAMS investigations may be obtained by contacting the ALARA/CCIP Program Office (376-9035), or by reviewing prior issues of this publication.

\subsection{ALARA TRAINING}

Effective and successful implementation of any ALARA program requires knowledge and understanding of the ALARA concepts. Consequently, training of personnel in ALARA, safety, and radiation principles is one of the most important elements in any effective ALARA program.

The majority of ALARA training at WHC is incorporated in other training packages as a basic theme that is reinforced throughout the training session. This reduces the number of necessary 
The majority of ALARA training at WHC is incorporated in other training packages as a basic theme that is reinforced throughout the training session. This reduces the number of necessary ALARA-specific courses and ensures that a consistent emphasis is placed on ALARA policy and philosophy.

During CY 1995, Technical Training conducted 3,550 training sessions that included the ALARA theme throughout, with 14,490 students completing the training. Some of the subjects covered in these training sessions included: Criticality Safety, Job Control Systems, and Radiological Worker Training, as well as Hanford General Employee Training. In addition, there is a specific emphasis placed on classic ALARA (radiological) in all courses relating to radiological training.

Efforts to raise the ALARA awareness of Hanford employees will continue to be one of the highest priority tasks of the WHC ALARA/CCIP Program Office.

ALARA Training for Technical Support Personnel, Course 020900, was established to meet the requirements of the HSRCM, Article 652, while providing a valuable training tool for Hanford personnel. During CY 1995, 382 Hanford employees attended this training. This specialized ALARA training provides technical support personnel (engineers, schedulers, procedure writers) with the basic ALARA principles, basic ALARA techniques, and exposure reduction techniques.

Training on ALARA documentation is provided in the courses outlined above, or specific documentation training may be obtained by contacting the WHC ALARA/CCIP Program Office (3769035/376-0818). This training is provided with no direct charge to the facilities.

\subsection{ALARA POINTS-OF-CONTACT}

The ALARA Points-of-Contact listing identifies the current ALARA committee chairperson designated by division, department, or facility management to coordinate the administration of the individual facility ALARA program. Support personnel representing engineering, health and safety, industrial safety, and pollution prevention are also listed in Table 1-7-1. 
Table 1-7-1. ALARA Council Members

\section{ALARA/CCIP PROGRAM OFFICE}

Radiological Control Manager

S. R. Johnson

$6-5855$

ALARA/CCIP Program Coordinator

O. D. Berglund

$6-9035$

ALARA Program Senior Health Physics Analyst

L. O. Waggoner

6-0818

\section{FACILITY SPECIFIC ALARA COMMITTEES}

B Plant/WESF

Facility Operations/PUREX

Facility Operations/Plutonium Finishing Plant

Fast Flux Test Facility

K-Basins Operations

Analytical Laboratories

Solid Waste Disposal/T-Plant

300 Area Liquid Effluent Facilities

200 Area Effluent Treatment

Solid Waste Management

East Tank Farms Transition Projects

West Tank Farms Transition Projects

Characterizations Projects

ORGANIZATIONAL ALARA COMMITTEES

ICF Kaiser Operations
H. G. Oglesbee

S. L. Hathaway

D. E. Kammenzind

A. M. Ostby

L. A. Nelsen

D. W. Humphrys, II

M. D. Nuzum

T. L. Woodford

J. W. DeLine

R. D. Warriner

D. W. Carlyle

R. J. Thomas

R. L. Brown

J. E. Kane, II

E. C. Benson, Jr.
$2-0080$

$2-0382$

$3-5608$

3-2564

6-0603

3-3143

3-5966

3-1573

2-3608

6-6956

3-0818

3-9893

2-2932

6-8387

6-0831

3-1707

6-6234

6-8737

2-1457 
WHC-SP-0564-40

This page intentionally left blank. 


\subsection{INDUSTRIAL SAFETY AND HYGIENE}

\subsection{INTRODUCTION}

The purpose of the Industrial Safety and Hygiene section is to provide a perspective on overall performance by WHC and BCS Richland, Incorporated (BCSR) on the Hanford Site. Additionally, this section provides an overall picture of WHC industrial safety and industrial hygiene activities through narrative and statistical data that identifies and statuses goals and initiatives, program development, and standards and training courses anticipated or completed and ready for use.

Aggressive case management has had a significant impact on reducing the severity of occupational injuries and illnesses. The WHC accident investigators continue to work closely with line management, employees, the cognizant safety engineer, and the health care provider to identify and mitigate hazards in the work environment and enable injured employees to remain productive in the work force. While maintaining appropriate medical treatment, employees are being returned to work on restricted duty when necessary which allows time for the employee to recuperate and expedites the employee's return to full capacity.

Industrial Safety and Fire Protection Programs offers "Case Management" training to managers. Some key ingredients they share on successful case management include the following.

- Communicate reporting expectations clearly to the workforce. Managers who have communicated both the Company and their own expectations clearly with employees have experienced the most success with injury reporting and case management.

- Involve employees. Employees are actively integrated into the accident investigation process.

- Investigate events immediately. By investigating events promptly, hazardous conditions are corrected sooner, preventing recurrence of injuries. Also, timely reporting contributes to more accurate reports; we tend to forget important information as time lapses.

- Interpret Bureau of Labor Statistics (BLS) Guidelines. WHC has three investigators trained to interpret the BLS Guidelines and assure that the correct Occupational Safety and Health Administration (OSHA) recordability decision is made, and supporting documentation maintained.

- Communicate with the injured/ill employee. It is important for managers to have frequent contact with employees who have suffered a job-related injury or illness. Not only is this important for contact with employees who are off work due to job-related injuries/illnesses, but also those who are able to remain in the workforce on restricted duty.

- Implement proactive return-to-work process. WHC managers, along with offsite and Hanford Environmental Health Foundation (HEHF) medical providers, have been successful in keeping injured employees on the job and providing modified work assignments to allow employees to remain productive in the workforce.

- Implement work conditioning programs. HEHF Worksite Health has implemented work conditioning programs to assist employees with education and, in turn, minimize injuries. 
- Overview recordability classifications independently. Overviews of WHC injury and illness record management by a recognized OSHA recordkeeping expert have been done to assure compliance with OSHA recordkeeping regulations.

One indicator, used to determine successes in reducing occupational injury/illness case rates, used by the United States Department of Labor is the comparison of companies with the same Standard Industrial Classification (SIC) codes. Table 2.1 shows how WHC, BCSR, and WHC Security case rates compare to those recorded by the Bureau of Labor Statistics, Department of Energy, and Washington State Department of Labor and Industries employers with the same SIC codes. Please note the data reporting periods from these sources; the latest available is charted and does not necessarily correspond to that of WHC data.

Table 2-1. Occupational Injury/Illness Case Rates Comparison

\begin{tabular}{|c|c|c|c|c|c|c|c|c|c|}
\hline \multicolumn{10}{|c|}{ Lost/Restricted Workday Case Incidence Rate Comparison } \\
\hline $\begin{array}{l}\text { Company/ } \\
\text { Org. } \\
\text { (SIC Code) }\end{array}$ & $\mid \begin{array}{c}\text { BLS SIC } \\
\text { CY 1992 } \\
\text { Rate }\end{array}$ & $\begin{array}{c}\text { BLS SIC } \\
\text { CY } 1993 \\
\text { Rate }\end{array}$ & $\begin{array}{l}\text { DOE } \\
\text { CY } 1992 \\
\text { Rate }\end{array}$ & $\begin{array}{c}\text { DOE } \\
\text { CY } 1993 \\
\text { Rate }\end{array}$ & $\begin{array}{c}\text { DOE } \\
\text { CY 1994 } \\
\text { Rate }\end{array}$ & $\mid \begin{array}{c}\text { WA } \\
\text { State } \\
\text { CY 1993 }\end{array}$ & $\begin{array}{c}\text { WHC } \\
\text { CY } 1993 \\
\text { Rate }\end{array}$ & $\begin{array}{c}\text { WHC } \\
\text { CY 1994 } \\
\text { Rate }\end{array}$ & $\begin{array}{c}\text { WHC } \\
\text { CY } 1995 \\
\text { Rate }\end{array}$ \\
\hline WHC (495) & 8.30 & 7.20 & 1.3 & 1.2 & 1.1 & 1.4 & 1.30 & 1.20 & .98 \\
\hline BCSR (737) & .60 & 0.60 & *N/A & *N/A & $*$ N/A & .80 & .85 & 1.13 & .44 \\
\hline $\begin{array}{l}\text { WHC Security } \\
\text { (738) }\end{array}$ & 2.40 & 2.30 & 1.6 & 4.2 & 4.1 & 3.60 & 2.10 & 2.60 & 1.83 \\
\hline \multicolumn{10}{|c|}{ Total Recordable Case Incidence Rate Comparison } \\
\hline WHC (495) & 16.30 & 13.70 & 3.0 & 3.1 & 2.9 & 6.10 & 4.10 & 4.10 & 3.65 \\
\hline BCSR (737) & 1.30 & 1.90 & $*_{\mathrm{N}} / \mathrm{A}$ & ${ }^{*} \mathrm{~N} / \mathrm{A}$ & ${ }^{*} \mathrm{~N} / \mathrm{A}$ & 2.20 & 2.73 & 4.62 & 3.21 \\
\hline $\begin{array}{l}\text { WHC Security } \\
\text { (738) }\end{array}$ & 5.20 & 5.20 & 4.7 & 6.60 & 6.0 & 9.50 & 3.20 & 4.50 & 3.92 \\
\hline
\end{tabular}

* DOE doesn't calculate BCSR separately from WHC.

\subsection{ONGOING INDUSTRIAL SAFETY AND HEALTH INITIATIVES}

\subsubsection{Voluntary Protection Program (VPP) - Noteworthy Activities During the Quarter}

During the fourth calendar quarter, each division completed activity in support of the CY 1995 President's Accident Prevention Council (PAPC) Safety and Health Goals. Planning commenced for development of CY 1996 PAPC Goals. Representives from each WHC division Accident Prevention Council (APC) met several times during the quarter to create a framework for continuous improvement initiatives for 1996. They were designed to achieve progress within the DOE-VPP. The primary goal and objectives were presented to the PAPC membership at the November meeting, with a two-week comment period established. Modifications/revisions were subsequently incorporated, with the final structure accepted by the PAPC in December. It appears as follows.

GOAL:

Achieve continual improvement of our safety culture through the use of the Voluntary Protection Program and Behavior-Based Safety. 


\section{OBJECTIVES:}

1. Organizations/Facilities will continue to perform self-evaluations using VPP tools.

2. The VPP Subcommittee will review/revise the 1995 Safety Improvement Self-Evaluation (SISE) document in alignment with the DOE-VPP Application Criteria.

3. Safety Improvement Plans (SIPs) will continue to be developed, utilized, and updated.

4. The PAPC will sponsor a 1996 "Hanford Safety Exposition"

5. A Team of APC representatives will be pro-active with DOE-RL to develop and implement a process for VPP recognition.

6. Managers will complete annual safety training.

7. At least one representative of each APC will complete a hazard recognition training course.

8. Organizations/Facilities will continue implementation of Behavior Based Safety.

9. Organizations/Facilities will enhance and share communications.

Also of note, during this time period, was the preliminary announcement by the DOE-RL of their consideration to sponsor a program of "local" VPP evaluation. This activity would provide an opportunity for individual divisions/facilities to verify their readiness for a DOE-HQ formal review through self-assessment, as well as to be recognized for successful achievements. At present, a group of worker volunteers representing WHC, BCSR, and ICF Kaiser Hanford Company (ICF KH) are being identified, with plans to assemble as a work team to develop a strategy and protocol for DOE should the "green light" be given.

Some of the notable activities undertaken during the fourth quarter of CY 1995, in support of VPP, are listed below.

2.2.1.1 Management Leadership. Management demonstrated visible support in the following areas:

- Support of the PAPC recommendation of adopting, "If It's Not Safe, Don't Do It," as the WHC/BCSR safety policy statement, and formally recognized the WHC employee who submitted the suggestion (via contest entry).

- Support for worker development of, and PAPC sponsorship to, the 1996 Safety Goals and Objectives.

- Support for publication of a "Worker Bill of Rights" document, developed from the contents of Safety Standard WKS-1 and supplemental worker input.

- Support of the Hanford Site "Stop Work Responsibility" statement (developed with worker involvement), through formal signature and approval.

2.2.1.2 Employee Involvement. The Tank Waste Remediation System (TWRS) Engineering Safety Council developed and distributed VPP cards to promote and communicate the VPP message. 
The TWRS East Tank Farms ALARA Group developed and displayed posters to communicate STAR (Stop, Think, $\underline{\text { Act, }}$ Review).

The TWRS 200 West Area Safety Council produced buttons with the message "Soaring for Safety", to communicate their personal support for worker safety.

Behavior-based "DO-RITE" activities continued in many organizations. Some of the subject areas under review are: home electrical safety, driving safety, crosswalk usage, location of Personal Protective Equipment (PPE), filing cabinets, and ergonomics.

Worker representatives participated in development of the "Worker Bill of Rights", "Stop Work Responsibility" document, and 1996 PAPC Safety and Health Goals.

The PUREX facility established a radiological work practice team to seek process improvements through "employee involvement." It has met with much success, and was shared with other divisions.

Employees participated in the development of safety and health-related poster presentations in support of the DOE-ES\&H Conference. These displays were incorporated into the December PAPC meeting activity, where topical messages were shared with the Division membership.

2.2.1.3 Hazard Prevention and Control. Electrical safety procedures were revised to address prejob walkdowns, stop work, recognition of good safety performance, inspection of new installations, accuracy of field drawings, de-energizing before digging, and supervision of subcontractors.

Five additional industrial safety and five additional industrial hygiene standards were approved for incorporation into the joint WHC/ICF KH manual system.

Implementation of the industrial hygiene task-based qualitative exposure assessment program (Enhanced Work Planning Demonstration Project) was initiated.

The TWRS Organization initiated a Safety Stewardship Review Process in which managers and employees work together to identify hazards for safety improvement, and track each item to a point of resolution.

2.2.1.4 Safety and Health Training. Commenced with OSHA Hazard Recognition Training, developed and sponsored by Health and Safety Training Services.

Internal review/evaluation was completed for Confined Space, Fall Protection, and Asbestos Control training classes.

Performance assessment training has been completed at B-Plant to support Hazardous Waste Operations and Emergency Response Regulations (HAZWOPER) Pilot.

Supervisor Training in Accident Reduction Techniques (START) training progressed in the TWRS Division. 


\subsubsection{Safety Meeting Improvement}

Effective safety meetings, pre-job safety meetings, etc., are a cornerstone of any successful safety program. In an effort to improve the reporting of safety meetings, the Safety/Security Meeting Report form was revised. It now provides a mechanism for recording and tracking safety issues. The new form is available through Forms Control and as a site-wide computer WordPerfect ${ }^{\bullet}$ macro, GEF270.

To assist with safety meeting planning efforts, a 12-month Safety Meeting Theme Planner has been developed for use in 1996. The Theme Planner depicts safety topics or issues which will be addressed each month. The Theme Planner covers each of these areas:

- Industrial Hygiene

- Health and Wellness programs

- Construction

- Worker Safety

This Planner, along with the information provided by the Safety Resource Center, provides the workforce with an effective method for maintaining awareness and safety/health knowledge, all year long, while lessening the time impact on daily workload by making the preparation of safety meetings more convenient. A Theme Planner can be obtained by calling Graphics on 373-3140 (Reference \#2G9610195.1C).

\subsubsection{Summary}

During Calendar Year 1995, WHC efforts to enhance worker safety and health were driven by the principles of the DOE-VPP. This single safety system provides the focus for building and influencing a positive safety culture. WHC line management and workforce recognize that this structured process is essential to achieve excellence in worker protection. The VPP serves as a road map for systematically recognizing and controlling hazards in the work environment through a unique manager/worker commitment to partnership and participation.

2.2.3.1 First Quarter. Each Division participated in completion of SISE. These exercises were worker driven/management lead, and helped to identify opportunities for improvement within the five Elements of VPP. Additionally, WHC completed formal response to DOE-HQ/EM-23 secondary comments on the formal VPP Application document. During the last week of January, a Team of Evaluators representing Westinghouse Electric Corporation and affiliated GOCOs conducted a VPP safety and health program review at B Plant, WESF, and TWRS. The results were not only used for continual improvement planning within the affected organizations, but were also shared as lessons learned data for other Divisions.

2.2.3.2 Second Quarter. The Hanford Safety Exposition was held at the County Fairgrounds, with over 5,500 people in attendance. The event supported completion of PAPC Goal No. 4. In early April, an initial VPP benchmarking visit was made to the Dow Chemical Company facility located in Freeport, Texas. Dow had volunteered to serve as a general industry mentor to WHC as part of the DOE-VPP Outreach Program. Three bargaining unit employees from HAMTC participated, as did a member of senior management. Also in this time frame, employees volunteered to speak as part of a VPP Theme at the 1995 Sharing Conference, and supported attendance at the OSHA Region X VPP Conference in Spokane, Washington. 
2.2.3.3 Third Quarter. Two members of the workforce served as presenters to support a VPP panel discussion at the National VPP Participants' Association Conference. Worker involvement was a focal point during this quarter. With organizational downsizing and restructuring taking root, it was becoming more evident that employee participation and contributions in all aspects of the safety program was the key to progress and enhanced safety performance. Each Division took the opportunity to review the role it's workforce was playing in day-to-day work activities and safety decision-making. Such posturing demonstrated a strong commitment to worker safety, increased the potential for safety program effectiveness, and attained alignment with the initiatives formalized in the DOE-EM Safety and Health Plan.

2.2.3.4. Fourth Quarter. During the final three months of 1995 , general activities in support of Worksite Analysis, Hazard Prevention and Control, and Safety and Health Training continued. Of note here was the work completed to revise safety and health standards, progress within the Enhanced Work Planning Demonstration Project, and commencement of worker hazard recognition training through Training Services. Strong gains continue to be made in the areas of Management Leadership and Employee Involvement. Success stories can be found in the development of a singular Safety Policy Statement, Worker Bill of Rights, and 1996 PAPC Safety Goal/Objectives.

In addition to these highlights, many contributions were made within individual work groups which, although significant, never received the publicity or notoriety they may have deserved. All were designed to help us manage and reduce our workplace risks, maintain worker safety and health as a fundamental value, and position us in the future for STAR recognition as a top performer in the DOE system, and beyond.

\subsection{INDUSTRIAL HYGIENE PROGRAMS}

\subsubsection{Industrial Hygiene (IH) Workscope Change}

The Industrial Hygiene Programs (IHP) group established Subject Matter Experts for IH programs to interface with facilities from a "company perspective," provide technical expertise and regulatory interpretation, support effective and timely responses to major issues, enhance programwide communication efforts.

The IHP group effectively managed and completed transition of the HEHF industrial hygiene workscope to WHC/ICF KH for exposure monitoring, IH equipment laboratory, and management of exposure records.

\subsubsection{Centralized Industrial Hygiene Equipment Laboratory (IHEL). The IHEL was} effectively transferred from HEHF to the WHC IHP group. Renovation and relocation of the laboratory was completed within the budget, on schedule and resulted in no disruption of site services. The IHEL serves as a technical resource for WHC/ICF KH project support industrial hygienists and ensures equipment obtained from the laboratory is operational, calibrated, and maintained in accordance with industry standards. A records management system ensures data integrity is supported by required documentation and is integrated with the instrument tracking system. To date, nearly 1,100 pieces of equipment have been bar coded and added to the inventory.

\subsubsection{Industrial Hygiene Exposure Monitoring Records System. As part of the HEHF} workscope transition to WHC/ICF-KH, area and personal exposure monitoring records and the Hanford Industrial Hygiene Database have been successfully transferred to the WHC IHP group for 
centralized records management. This includes electronic data, existing field records that need to be incorporated into the records management system, and entry of new filed records into the system.

A new database system, Sentry 2000 , will replace the existing Hanford Industrial Hygiene Database to provide industrial hygienists with data entry and query/trending capabilities in a "userfriendly" system. To date, installation of the software, training of key staff, identification of required modifications, and initial mapping of data for conversion from the existing system into the new system has been accomplished. The new system is expected to be operational June, 1996.

\subsubsection{Exposure Assessment Activities. Phase I of the Enhanced Work Planning Demonstration} Project has been successfully completed a the Hanford Site. this is a cooperative project among WHC, DOE-RL, DOE-HQ, and HEHF to evaluate concepts and approaches designed to improve work planning from both operations and worker protection standpoints. Enhancements address teamwork and worker involvement in planning, integration of exposure assessment, and coordination of information flow between medical, industrial hygiene and the worker.

Phase II, initiated in the fourth quarter of CY 1995, finalizes enhancements identified from Phase I with implementation planned at various facilities across the site. A key element will be demonstrating effective linkages between pre-job planning, medical, line management and industrial hygiene.

2.3.1.4 Respiratory Protection. WHC identified several areas to improve efficiency and costeffectiveness of activities related to respiratory protection services and implemented the following workscope changes to streamline the process.

- The workscope for respirator fit testing, including the applicable training, equipment, and records management was effectively transferred from HEHF to WHC.

- Secondly, the workscope for pick up, testing, maintenance, and delivery of respiratory protective equipment was transferred from WHC IHP to the Hanford Fire Department and to Intrastate Nuclear Services.

\subsubsection{WHC-CM-1-11, Industrial Hygiene Manual}

The WHC-CM-1-11, Industrial Hygiene Manual, consolidates WHC and ICF KH industrial hygiene requirements form several manuals and is based on recent changes in DOE Orders and OSHA requirements. WHC-CM-1-11 provides a unified approach to health and safety across the site. The first programs added to the manual resulted in closure of DOE milestones and include: Lead Control, Heat Stress Control, and Confined Space. Several other programs are pending final approval and will be available on HLAN soon.

\subsubsection{Safety Department Administrative Manual}

The WHC Safety Department Administrative Manual provides technical and implementing procedures for Industrial Hygiene, Industrial Safety, Fire Protection, and Nuclear Safety, organizations. The IH section has been expanded to include the IH Technician Training Program and technical procedures for: Evaluation and Control of Synthetic Vitreous Fiber Exposures, Qualitative Exposure Assessment, and Office Ergonomic Assessment. In addition, 28 standard operating procedures have been developed to ensure consistent application and use for specific instrumentation. Other procedures are being finalized which will complete the IH section of the SDAM. 


\subsection{TOPICS OF INTEREST}

\subsubsection{Hanford Site Safety and Health Exposition "Expo '96"}

WHC, BCSR, ICF KH, HEHF, along with several other businesses and Union members, will team to provide an interactive, fun and educational opportunity for employees and their families.

Expo ' 96 will be held April 10 through 11, 1996, at the Benton-Franklin County Fairgrounds. The event will take place from 7:30 a.m. to 7:00 p.m., daily. Expo will target the "grassroots" workforce during the daytime and evenings will take on a theme of off-the-job, family safety.

Expo will provide attendees with an opportunity to participate in interactive demonstrations by on- and off-site personnel and to view and/or partake in approximately 80 different exhibits and demonstrations which illustrate how safety equipment, as well as health and wellness programs can protect an individual at work and off-the-job.

\subsubsection{Safety Resource Center}

Safety Awareness and Performance has safety meeting literature available via Hanford Information, the Safety Meeting Section, on Hanford Local Area Network (HLAN) as a way to heighten safety awareness, encourage employee involvement, and make group safety meetings informative. Particular safety topics, accompanied by a Safety Meeting Lesson Plan, are provided

each month. Topics selected for Hanford Information during the fourth quarter of 1995, include:

\section{October 1995}

National Fire Prevention Autumn Safety

\section{November 1995}

Winter Weather

Hypothermia

Great American Smokeout

\section{December 1995}

Safety Improvement Plans

Stress \& the Holidays

Holiday \& Electrical

Case Management

In addition to the lesson plans that are available on Hanford Information, there is also a listing of safety meeting guest speakers. These are individuals that provide a safety meeting presentation on their area of expertise. The "Safety Resource Video Catalog" and some safety meeting guidelines and pointers can also be located in this section of Hanford Information.

Many resources are available through the Safety Resource Center to assist individuals with conducting effective safety meetings, and to provide information on safety and health topics.

Employees are encouraged to share these resources with their families and friends. Available resources include videos, literature, awareness items, and support with individual safety programs. For assistance, contact the Safety Resource Center on 376-9059, 376-8990, or visit MO-286, 200 East Area. 


\subsection{COMPANY-WIDE AND DEPARTMENT-LEVEL TRENDING AND ANALYSIS}

The following information provides an overview of the incidents being reported on site in the areas of occupational injuries/illnesses, and government vehicle accidents. This is accomplished through the compilation of charts, trending information, and recommendations for improvement. The data has been tabulated and analyzed on both a company-wide level and for each department. Management is encouraged to share this information with employees as a way to heighten awareness, realizing that most injuries involve some element of an at-risk behavior. We need to continue to foster a safety culture where all individuals are comfortable looking out for not only their own safety, but the safety of coworkers as well.

All WHC/BCSR occupational injury/illness information is available via Soft Reporting on HLAN. This report is updated weekly. In addition to providing the number of accidents for each organizational code or facility, the report gives a description of each accident, including location, jobtype, and cause of injury. This provides each manager and their employees with a means to focus on what types of accidents are occurring (for trending purposes), and ways to prevent recurrence.

Appendix B-1 provides a list of resources and services available to assist the workforce with injury prevention, accident investigation, and safety awareness efforts.

\subsubsection{Occupational Injury/Illness Incidence Rates}

WHC once again achieved significant improvement in its overall safety performance as reflected by the injury/illness incidence rates. Incidence rates with one exception (Restricted Work Cases Only Incidence Rate) reflect sharp reductions. The increase in the Restricted Work Case Incidence Rate appears to be the result of effective case management activity and the return to work in a partial duty capacity of employees who may otherwise have been off work due to a work-related injury/illness.

Incidence and Severity rates dropped by significant margins when compared with CY 1994. The Lost/Restricted Workday Severity rate plummeted downward by $60 \%$ and not far behind was the decrease by $58 \%$ in the Workdays Away Only Severity Rate. The Lost Workday Away Only Case Rate registered an impressive $47 \%$ reduction and the Lost/Restricted Workday case Incidence Rate was $16 \%$ below the 1994 rate.

Strains/Sprains continue to be the leading types of injuries representing $31 \%$ of all Recordable injuries/illnesses and 59\% of the Lost/Restricted cases during CY 1995. Cumulative Trauma Disorders were the leading type of illnesses. They were responsible for $19 \%$ of all Recordable injuries/illnesses and 12\% of the CY 1995 Lost/Restricted Workday cases. Refer to Table 2-2 for the two-year statistical comparison.

Declines in both of the above conditions were realized during CY 1995. These declines can be attributed to enhanced employee awareness, ergonomic adjustments to employee workstations/tasks, early detection and effective treatment by medical staff, and improved case management techniques. 
Table 2-2. WHC Occupational Injury/Illness CY 1994 - CY 1995 Statistics Comparison

\begin{tabular}{|c|c|c|c|c|}
\hline Time Period & $\begin{array}{c}\text { First Aid } \\
\text { Cases }\end{array}$ & $\begin{array}{c}\text { First Aid } \\
\text { Case Rate }\end{array}$ & $\begin{array}{c}\text { Total } \\
\text { Recordable Cases }\end{array}$ & $\begin{array}{c}\text { Total Recordable } \\
\text { Case Incidence Rate }\end{array}$ \\
\hline \hline CY 1994 & $\mathbf{7 6 2}$ & $\mathbf{7 . 7 6}$ & 395 & 4.02 \\
\hline CY 1995 & $\mathbf{5 7 3}$ & 7.14 & 292 & $\mathbf{3 . 6 4}$ \\
\hline
\end{tabular}

\begin{tabular}{|c|c|c|c|c|c|c|}
\hline Time Period & $\begin{array}{c}\text { Recordable } \\
\text { Cases } \\
\text { Resulting in } \\
\text { Lost/Restricted } \\
\text { Workdays }\end{array}$ & $\begin{array}{c}\text { Lost/ } \\
\text { Restricted } \\
\text { Workday } \\
\text { Case } \\
\text { Incidence } \\
\text { Rate }\end{array}$ & $\begin{array}{c}\text { Cases } \\
\text { Involving } \\
\text { Days Away } \\
\text { from Work }\end{array}$ & $\begin{array}{c}\text { Lost } \\
\text { Workday } \\
\text { Away Only } \\
\text { Case } \\
\text { Incidence } \\
\text { Rate }\end{array}$ & $\begin{array}{c}\text { Cases } \\
\text { Involving } \\
\text { Days of } \\
\text { Restricted } \\
\text { Work } \\
\text { Activity } \\
\text { Only }\end{array}$ & $\begin{array}{c}\text { Restricted } \\
\text { Work } \\
\text { Activity } \\
\text { Only Case } \\
\text { Incidence } \\
\text { Rate }\end{array}$ \\
\hline \hline CY 1994 & $\mathbf{1 1 8}$ & $\mathbf{1 . 2 0}$ & $\mathbf{7 2}$ & $\mathbf{0 . 7 3}$ & $\mathbf{4 6}$ & $\mathbf{0 . 4 7}$ \\
\hline CY 1995 & $\mathbf{8 1}$ & $\mathbf{1 . 0 1}$ & $\mathbf{3 1}$ & $\mathbf{0 . 3 9}$ & $\mathbf{5 0}$ & $\mathbf{0 . 6 2}$ \\
\hline
\end{tabular}

\begin{tabular}{|c|c|c|c|c|c|c|}
\hline Time Period & $\begin{array}{c}\text { No. of } \\
\text { Lost/ } \\
\text { Restricted } \\
\text { Workdays }\end{array}$ & $\begin{array}{c}\text { Lost/ } \\
\text { Restricted } \\
\text { Workday } \\
\text { Severity Rate }\end{array}$ & $\begin{array}{c}\text { No. of } \\
\text { Workdays } \\
\text { Away Only }\end{array}$ & $\begin{array}{c}\text { Workdays } \\
\text { Away Only } \\
\text { Severity } \\
\text { Rate }\end{array}$ & $\begin{array}{c}\text { No. of Days } \\
\text { Restricted } \\
\text { Work Activity }\end{array}$ & $\begin{array}{c}\text { Restricted } \\
\text { Work Activity } \\
\text { Severity } \\
\text { Rate }\end{array}$ \\
\hline \hline CY 1994 & 4,469 & 51.44 & 1,476 & 15.03 & 2,993 & 30.47 \\
\hline CY 1995 & 1,654 & 20.61 & 510 & 6.35 & 1,144 & 14.25 \\
\hline
\end{tabular}

\subsubsection{Lost/Restricted Workday Case Incidence Rates}

The cumulative CY 1995 lost/restricted workday case incidence rate (1.01) is 16 percent below the company's CY 1994 rate (1.20), and also 41 percent below the DOE CY 1991-93 Average (1.70). (Figure 2-1)

The CY 1995 strains/sprains injury category is down 24 lost/restricted cases from the same time period in CY 1994, but the strains/sprains injury category still accounts for 59 percent of the total lost/restricted workday cases.

The control chart (Figure 2-2) plots the CY 1990 through CY 1995 monthly lost/restricted workday case incidence rates. A control line shift took place in May 1993 when WHC initiated its "Making Safety First: Campaign '93." The monthly lost/restricted case rate continues to be in control. The rate is lower for CY 1995 than that of the previous years. 
Figure 2-1. WHC Lost/Restrlcted Workday Cases Cumulative Incldenco Rate

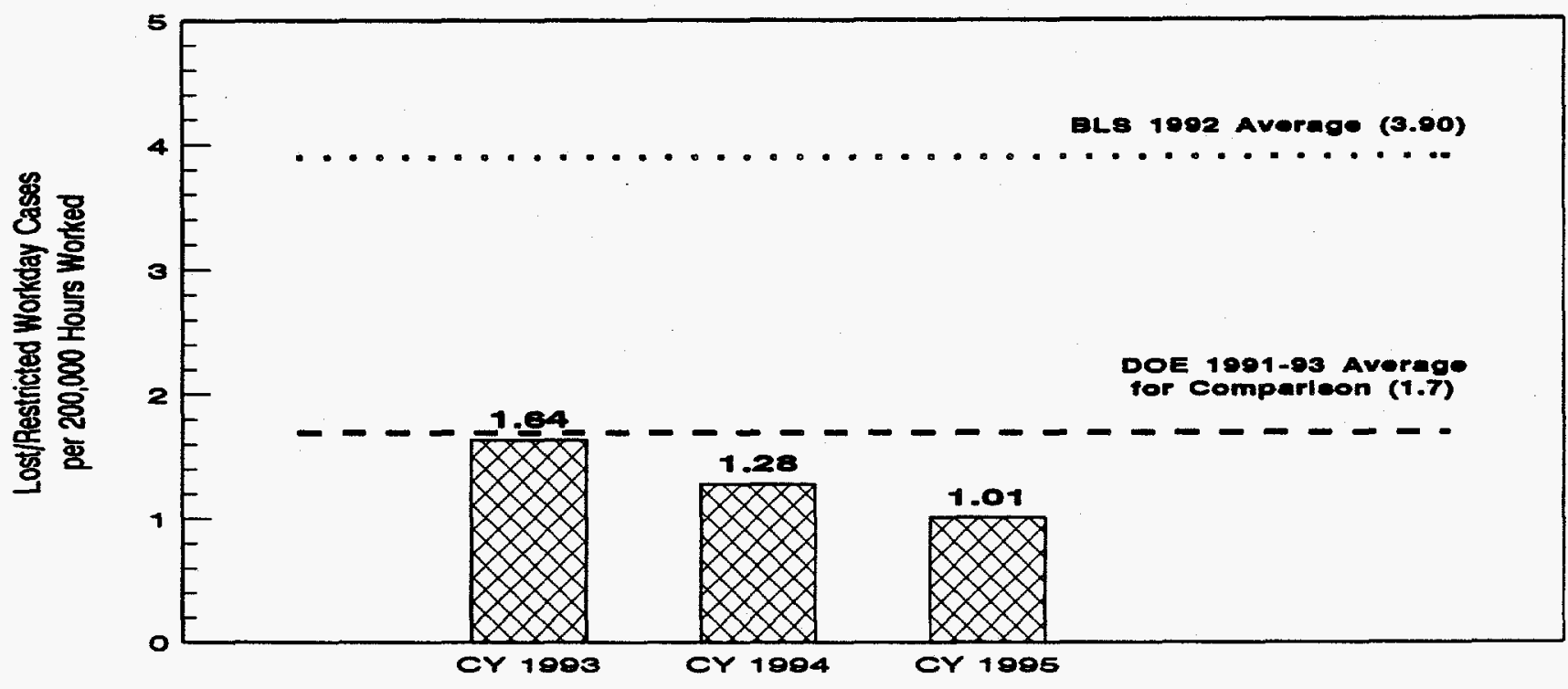

FIgure 2-2. WHC Lost/Restricted Workday Case Monthly Incidence Rates CY 1990 - CYTD 1995 - 3 Standard Deviations

CY 1980 - CY 1993 Monthly Fates inolude groups that tranaferred to ICF KH Operationa on $01 / 01 / 94$

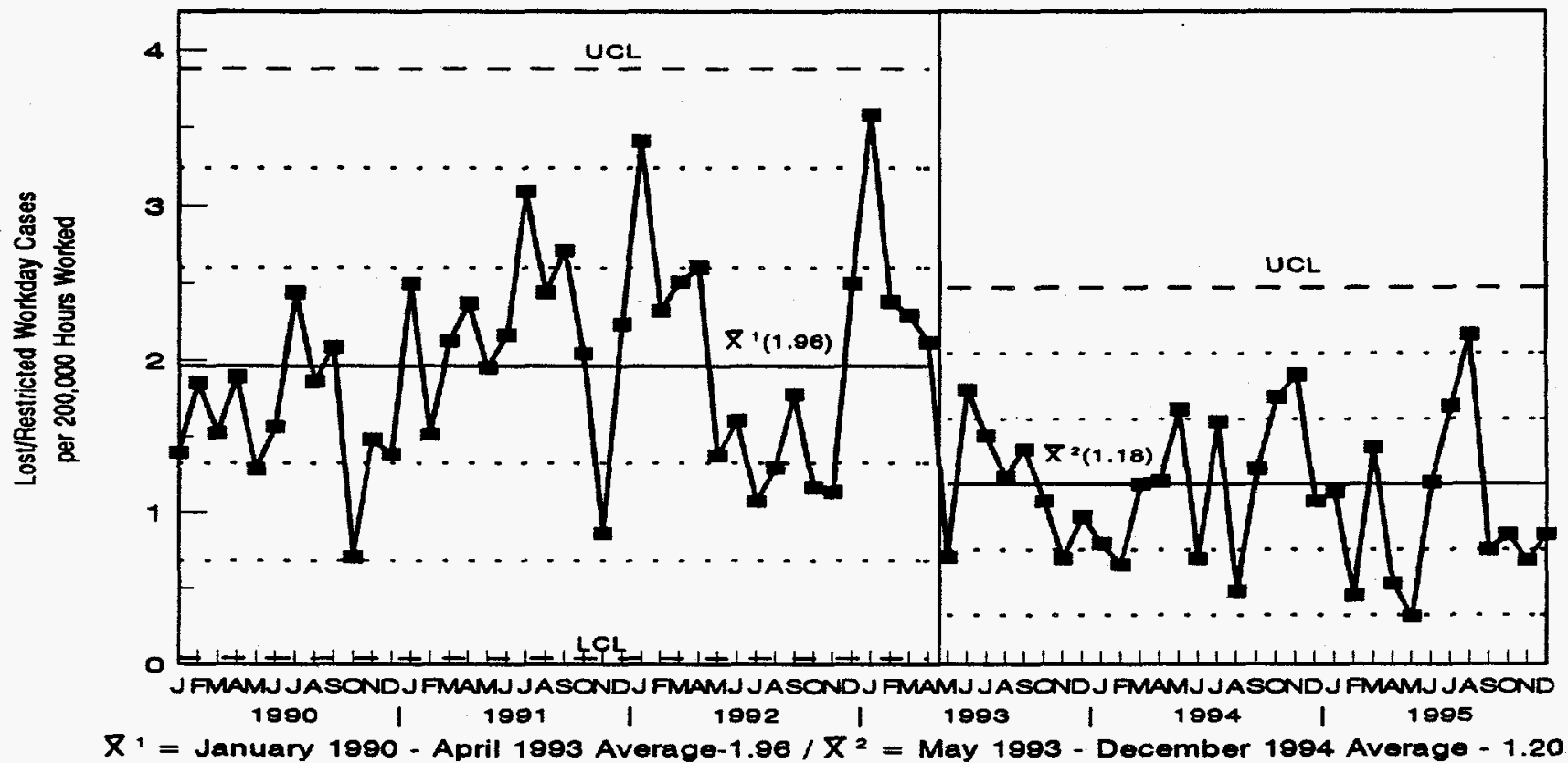




\subsubsection{Lost/Restricted Workday Incidence Rates}

Figure 2-3 provides the CY 1995 breakdown, by departments, of the lost workday away and restricted workday incidence rates. The combined cumulative CY 1995 lost workday away (6.35) and restricted workday (14.25) incidence rates of 20.61 are 55 percent below the DOE 1991-93 Average (45.90).

The control chart (Figure 2-4) plots the CY 1990 through CY 1995 monthly lost/restricted workday incidence rates. A control line shift took place in May 1993 when WHC initiated its "Making Safety First: Campaign '93." Since November of 1994, the monthly lost/restricted workday incidence rates remain below the average of 47.12 . Some of the injuries that occurred during the year are continuing to accumulate days, which will affect the incidence rates.

Flgure 2-3. WHC Lost/Reatrieted Workday Incldence Ratee By Dopartmont - CY 1006

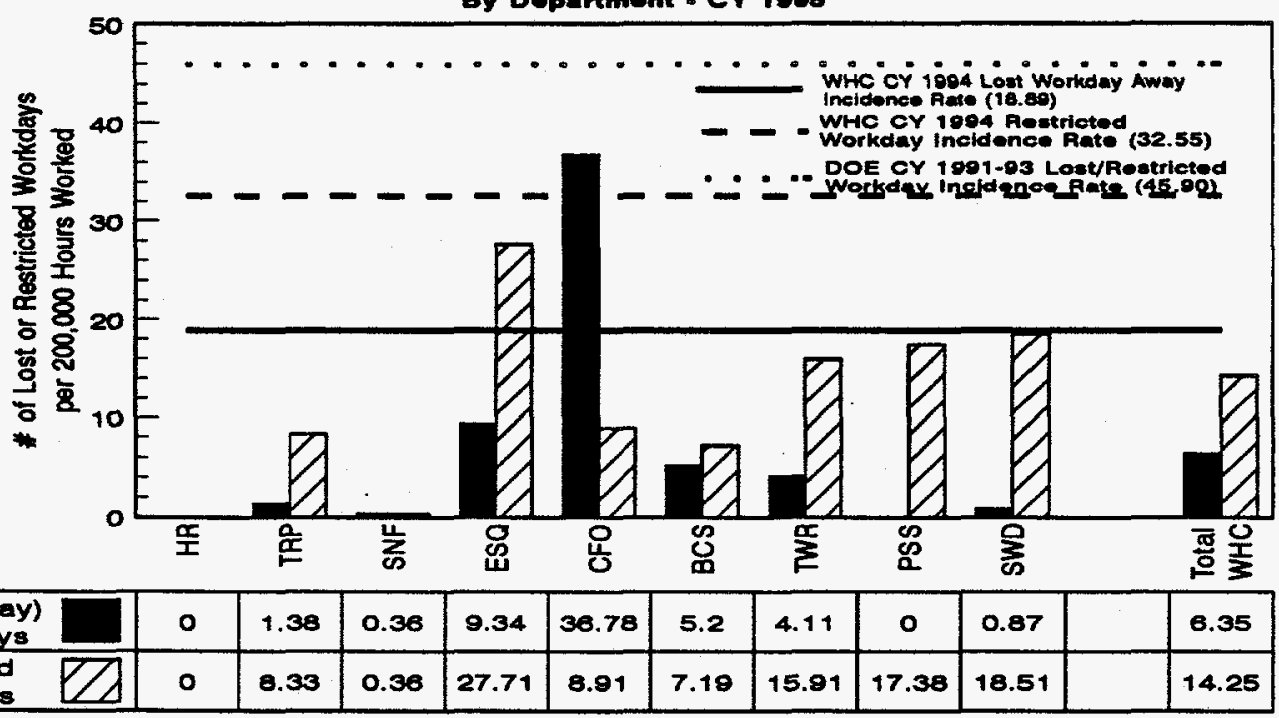

Flgure 2-4. WHC LostRestricted WORKDAY Monthly Incidence Rates CY 1000 - CrTD 1005 - 3 Standard Doviations

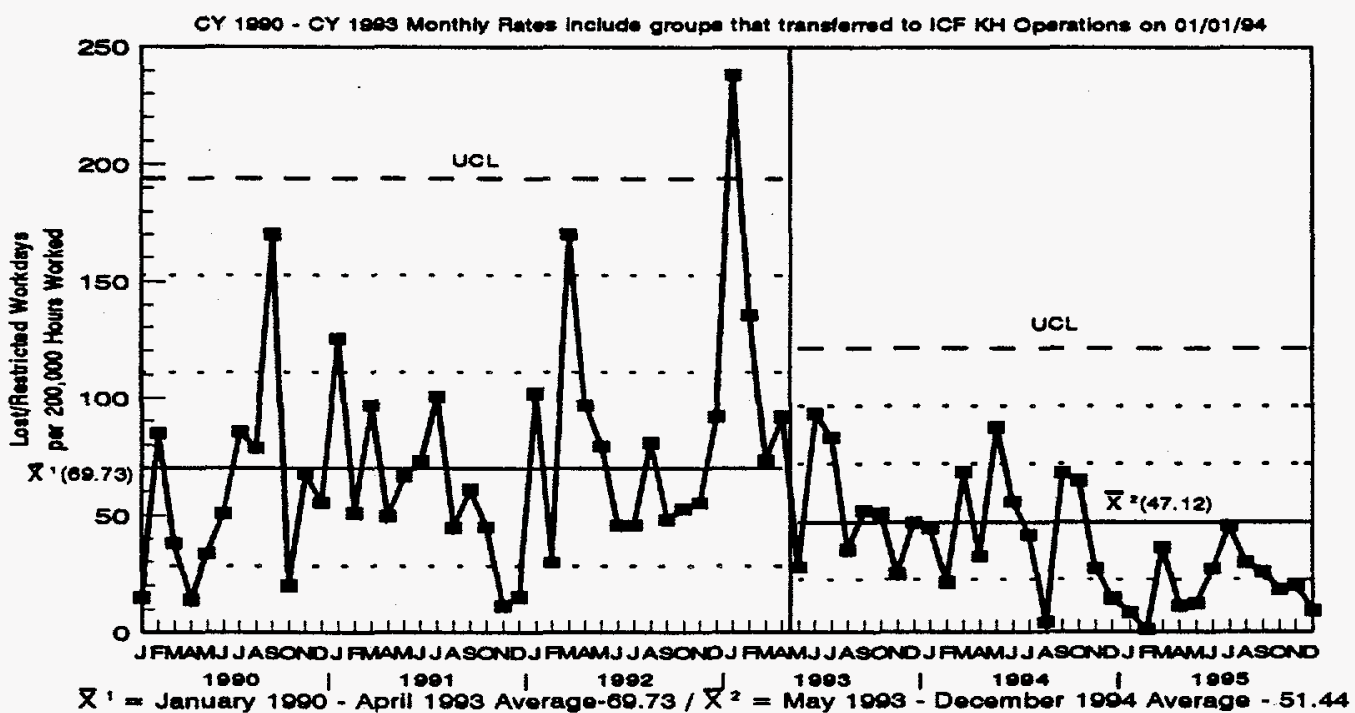




\subsubsection{Total Recordable Case Incidence Rates}

The cumulative CY 1995 total recordable case incidence rate (3.64) is 10 percent below the below the company's CY 1994 rate (4.02), and 2 percent above the DOE CY 1991-93 Average (3.73). (Figure 2-5)

The control chart (Figure 2-6) plots the CY 1990 through CY 1995 monthly total recordable case incidence rates. A control line shift took place in May 1993 when WHC initiated its "Making Safety First: Campaign '93." The monthly total recordable case rate continues to be in control.

Figure 2-5. WHC Total Recordable Cases Cumulative Incidence Rate

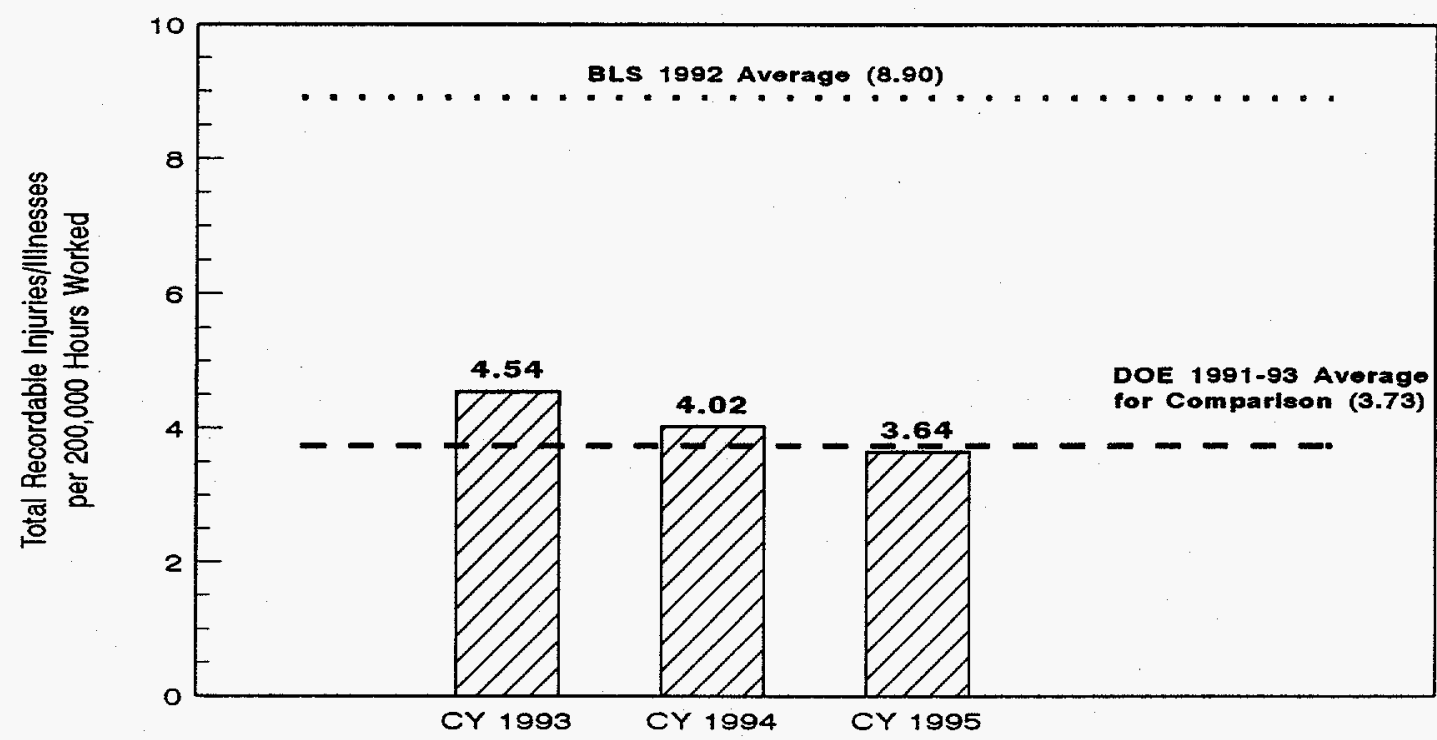

Figure 2-6. WHC Total Recordable Case Monthly Incidence Rates CY 1990 - CY 1995 - 3 Standard Devlations

CY 1990 - CY 1993 Monthly Rates inciude groups that transferred to ICF KH Operations on 01/01/94

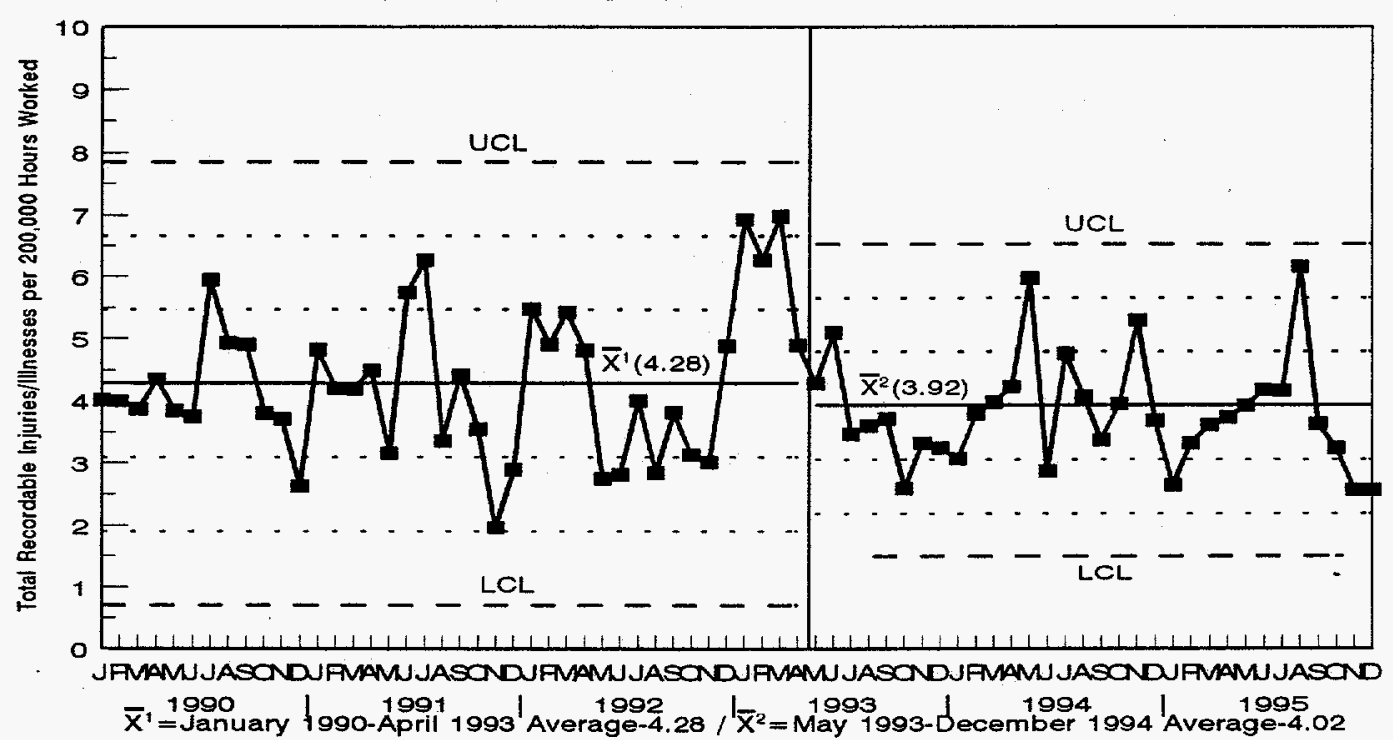


2.5.5 Occupational Injuries/Illnesses By Type

Figure 2-7. First Ald Only by Type (573 Cases)

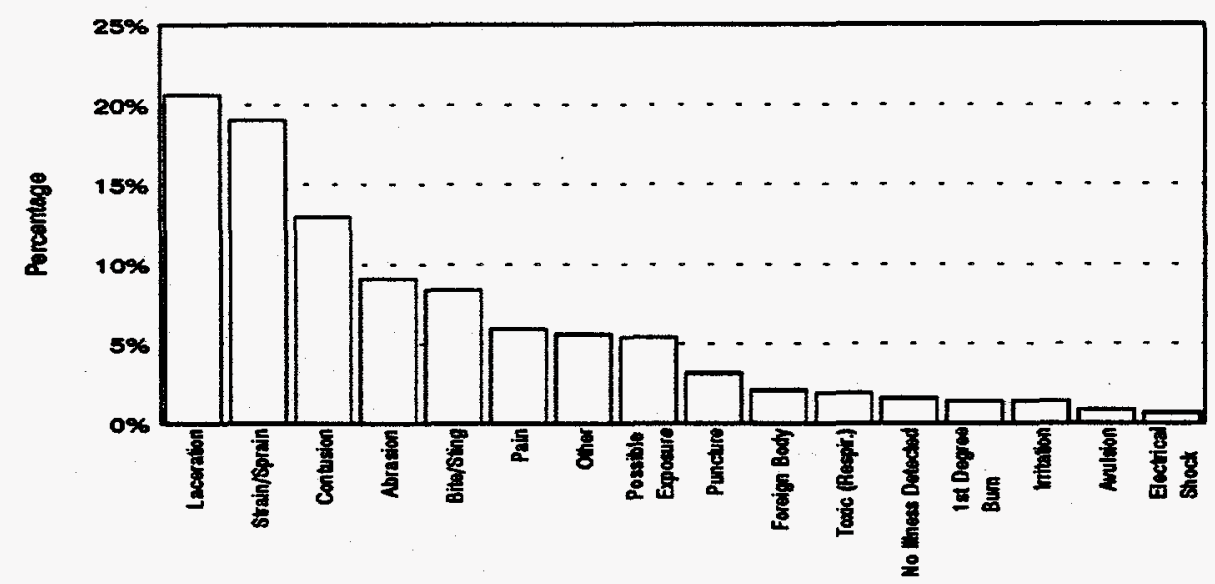

\begin{tabular}{|l|l|l|l|l|l|l|l|l|l|l|l|l|l|l|l|l|}
\hline $\begin{array}{l}\text { Number } \\
\text { Of Cakes }\end{array}$ & 110 & 100 & 74 & 82 & 40 & 34 & 32 & 31 & 10 & 12 & 11 & 0 & 0 & 0 & 6 & 4 \\
\hline
\end{tabular}

Figure 2-8. Total Recordable Injuries/linesees by Type (292 Cases)

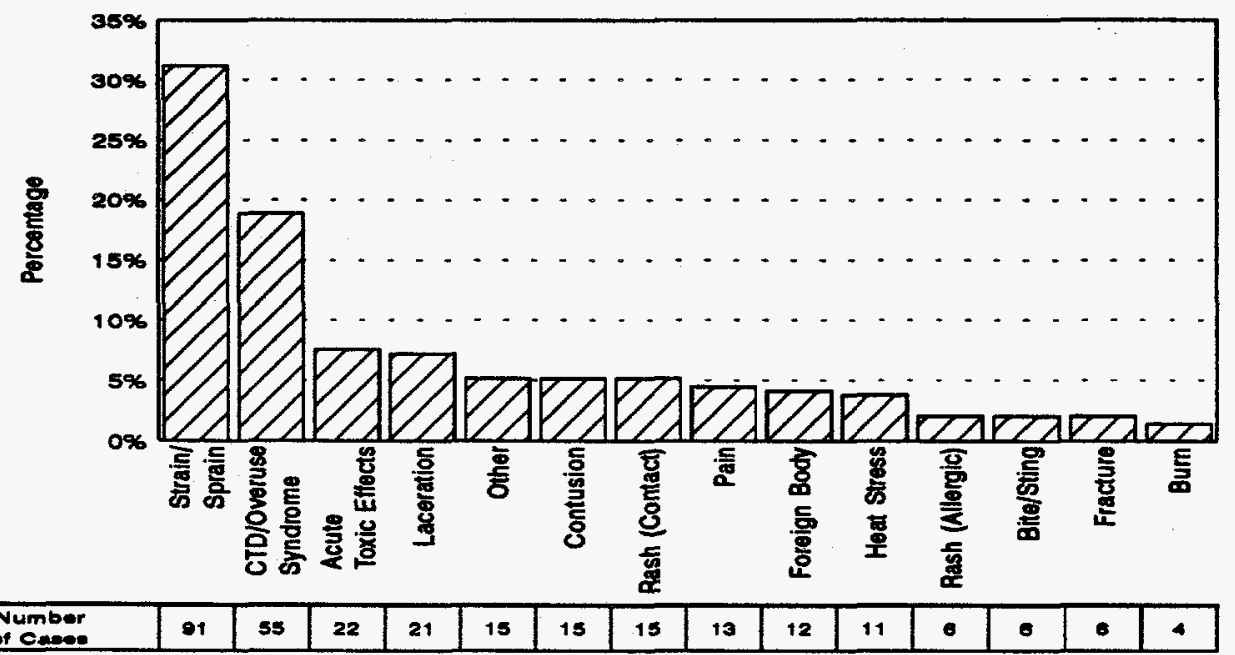

Figure 2-9. Lost/Restricted Workday Cases by Type (81 Casee)

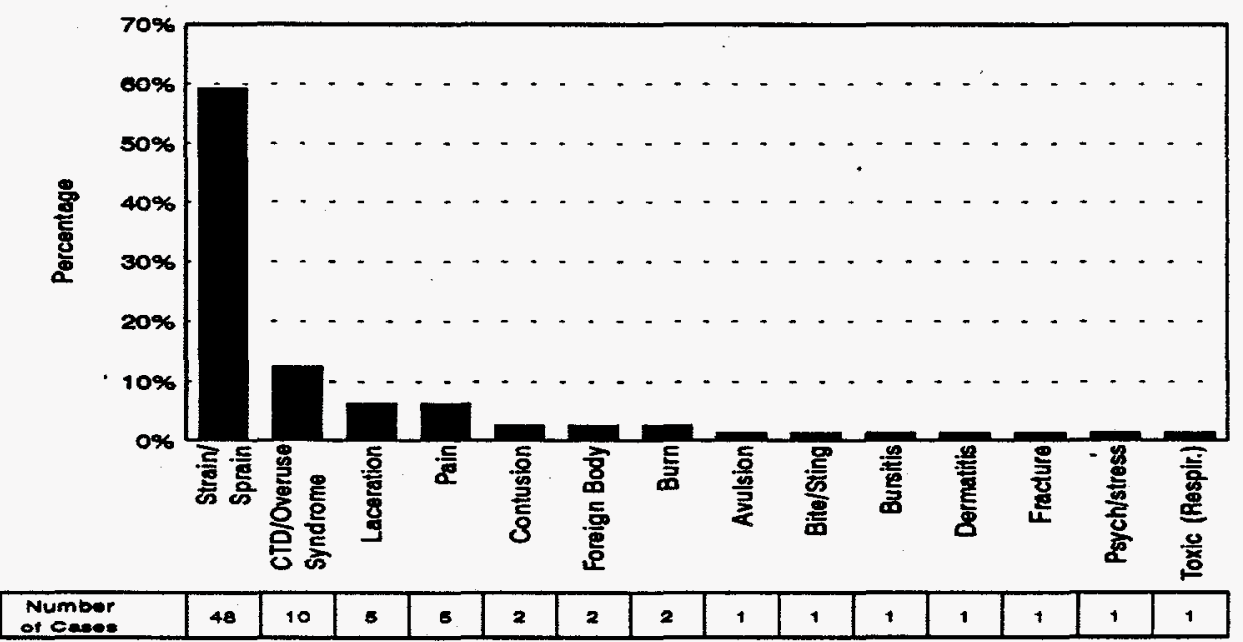




\subsubsection{Occupational Injuries/Illnesses By Body Group Injured}

Figure 2-10. First Aid Only by Body Group Injured (573 Cases)

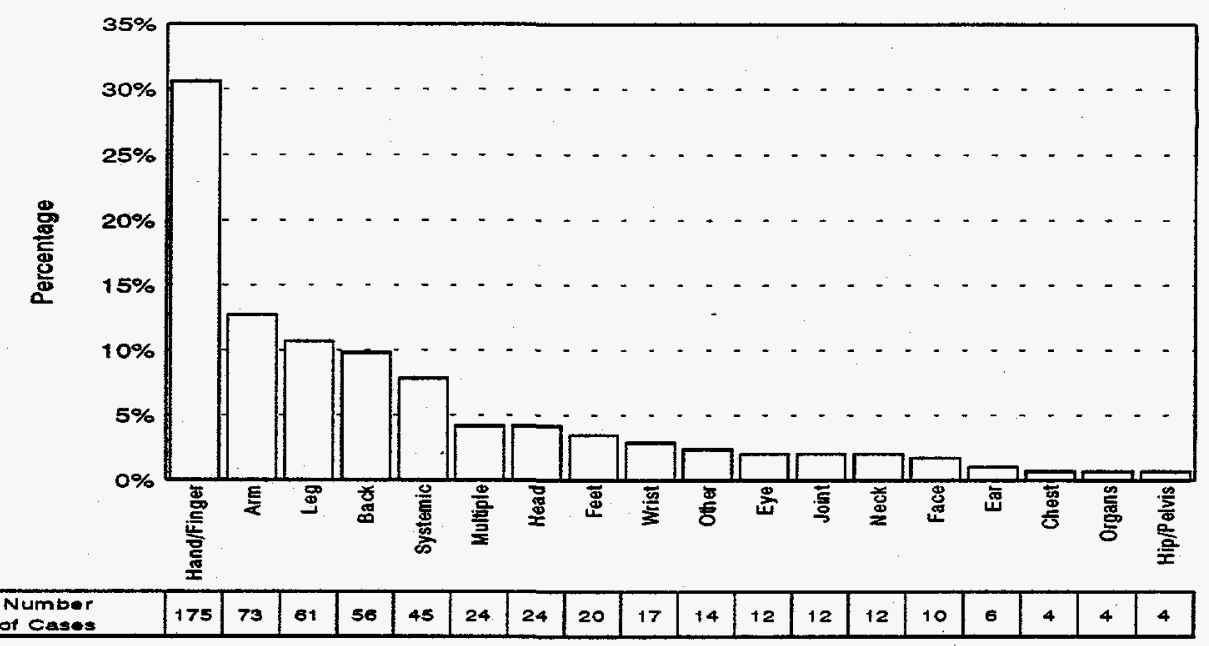

Figure 2-11. Total Recordable Injuries/llinesses by Body Group Injured (292 Cases)

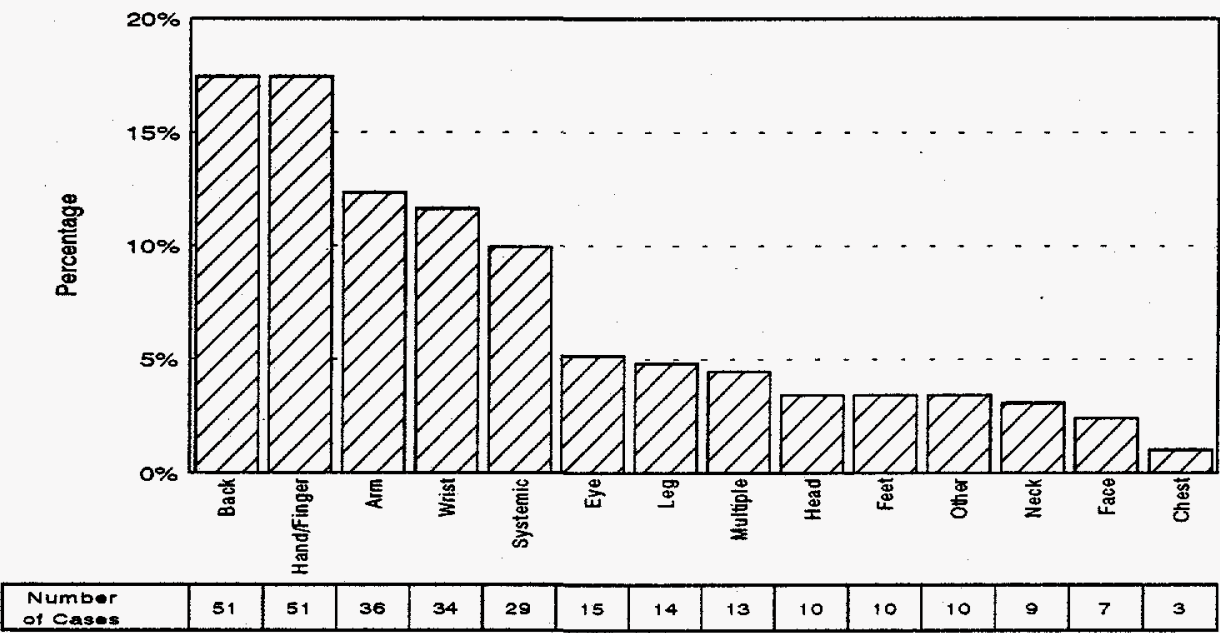

Figure 2-12. Lost/Restricted Workday Cases by Body Group Injured (81 Cases)

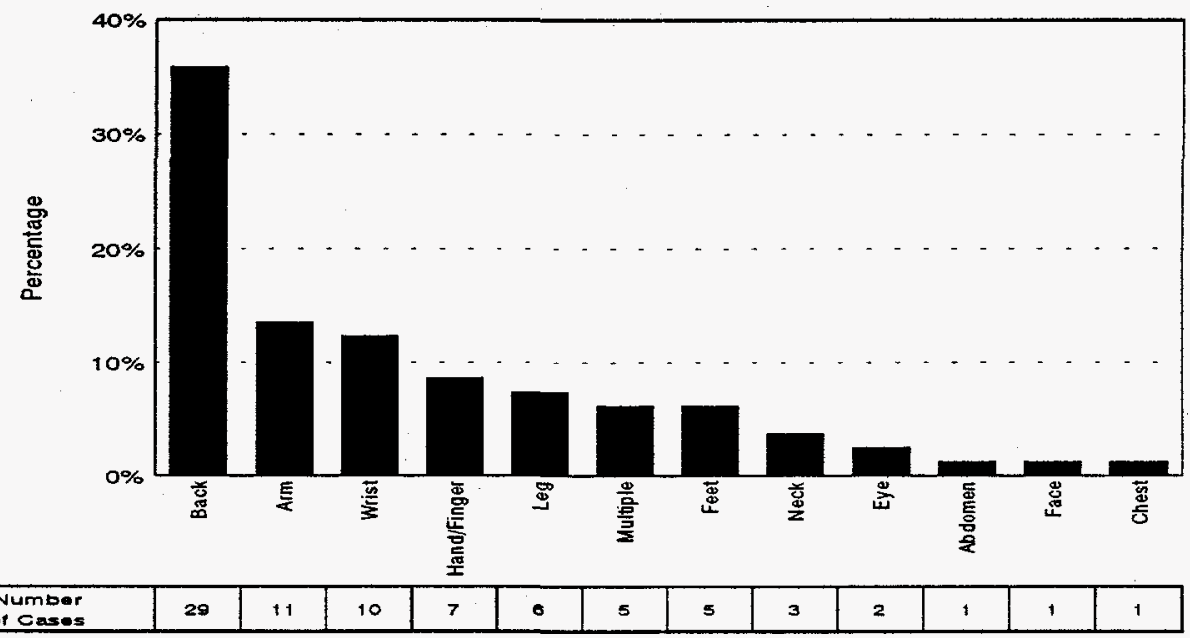




\subsubsection{Occupational Injuries/Illnesses By Cause}

Figure 2-13. First Aid Only by Cause (573 Cases)

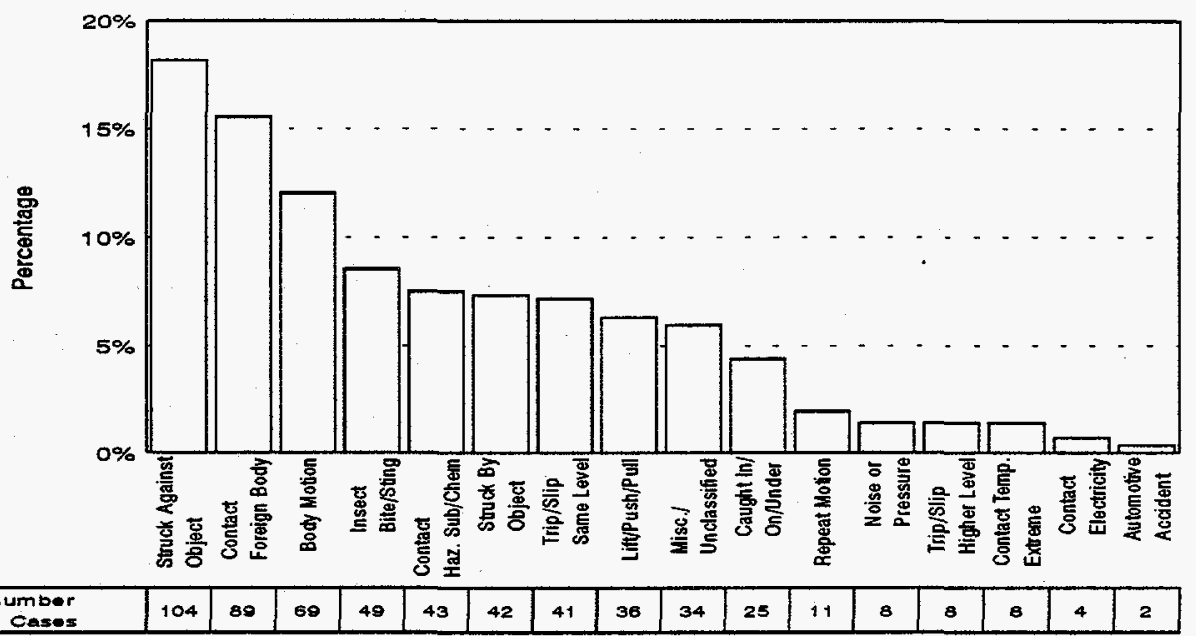

Figure 2-14. Total Recordable Injuries/llinesses by Cause (292 Cases)

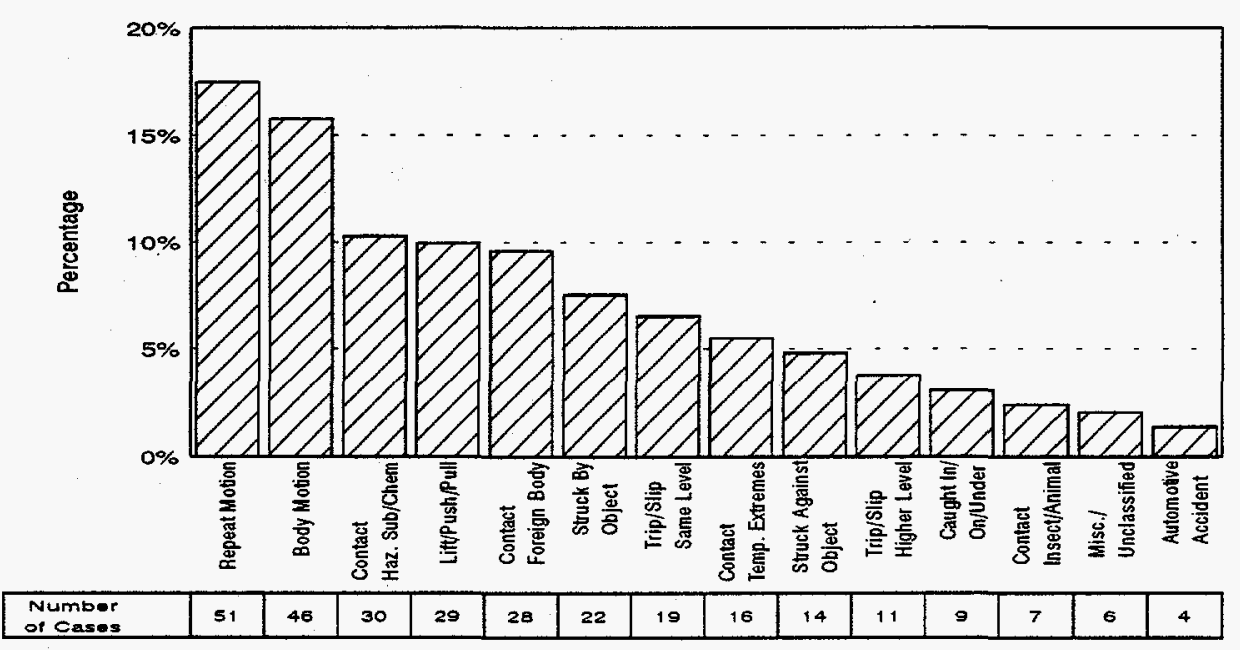

Figure 2-15. Lost/Restricted Workday Cases by Cause (81 Cases)

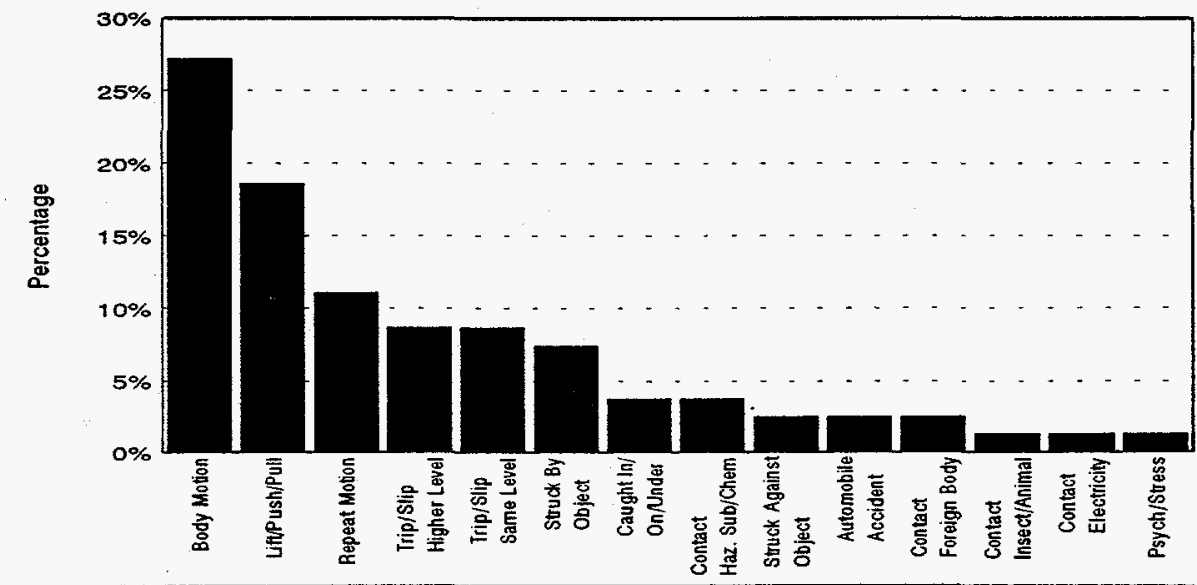

\begin{tabular}{|l|l|l|l|l|l|l|l|l|l|l|l|l|l|l|}
\hline $\begin{array}{c}\text { Number } \\
\text { of Cases }\end{array}$ & 22 & 15 & 9 & 7 & 7 & 6 & 3 & 3 & 2 & 2 & 2 & 1 & 1 & 1 \\
\hline
\end{tabular}


2.5.8 Occupational Injuries/Illnesses By Job Type

Figure 2-16. First Ald Only by Job Type (573 Cases)

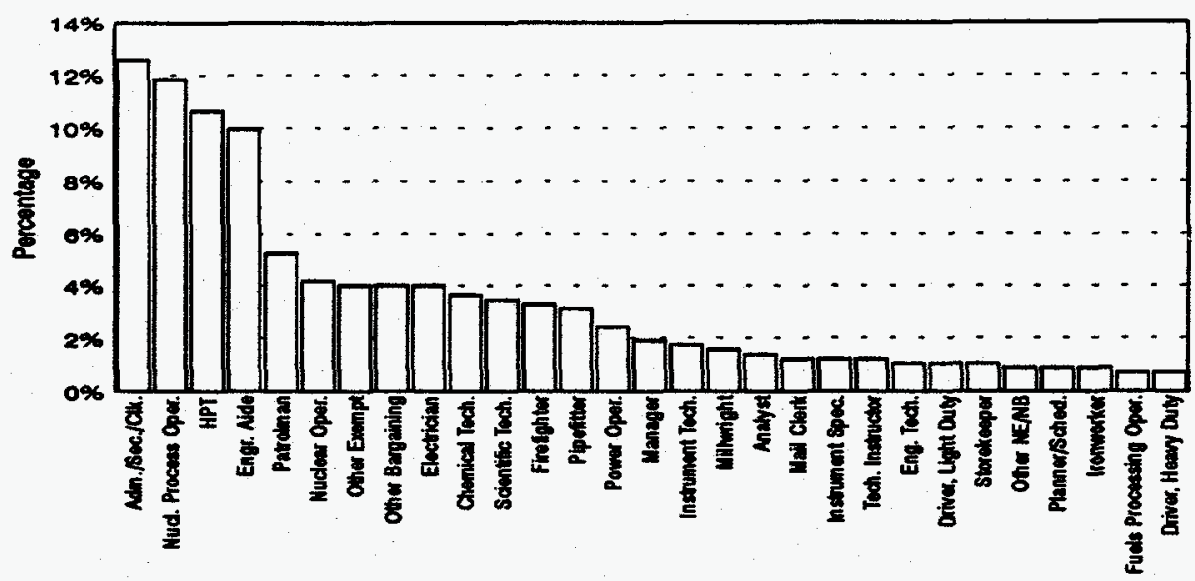

\begin{tabular}{|l|c|c|c|c|c|c|c|c|c|c|c|c|c|c|c|c|c|c|c|c|c|c|c|c|c|c|c|c|c|}
\hline $\begin{array}{l}\text { Number } \\
\text { of Ceee. }\end{array}$ & 72 & 00 & 61 & 57 & 30 & 24 & 23 & 28 & 23 & 21 & 20 & 10 & 19 & 14 & 11 & 10 & 0 & 0 & 7 & 7 & 7 & 0 & 0 & 0 & 5 & 5 & 5 & 4 & 4 \\
\hline
\end{tabular}

Figure 2-17. Total Recordable injuries/lilinesees by Job Type (292 Cases)

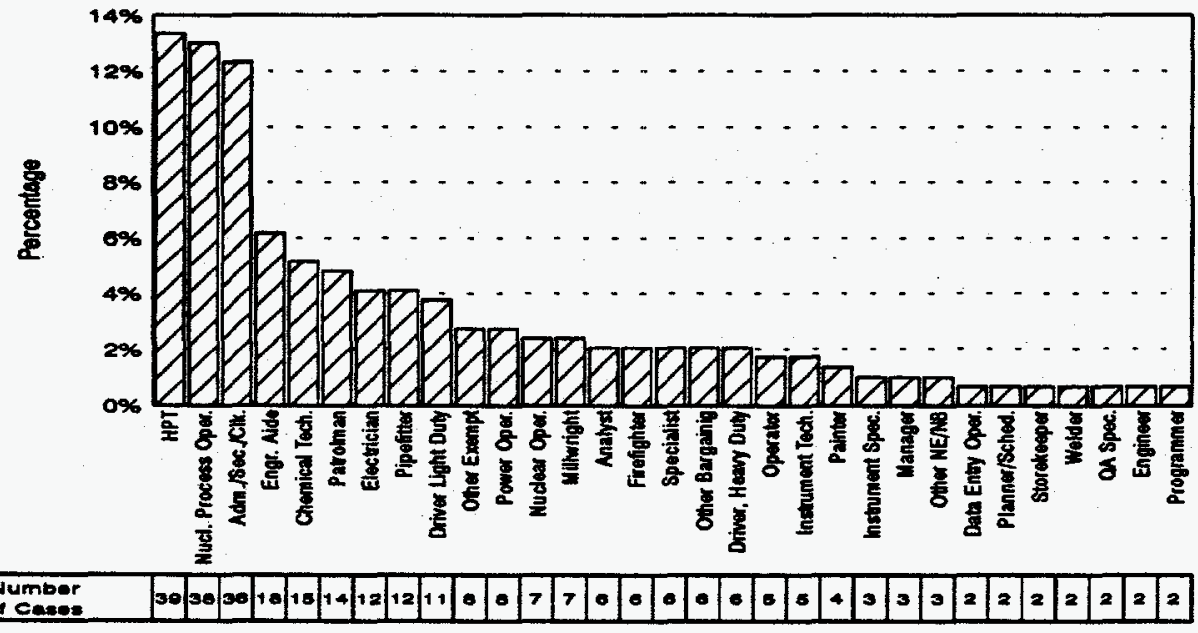

Figure 2-18. Lost/Pestricted Workday Cases by Job Type (81 Cases)

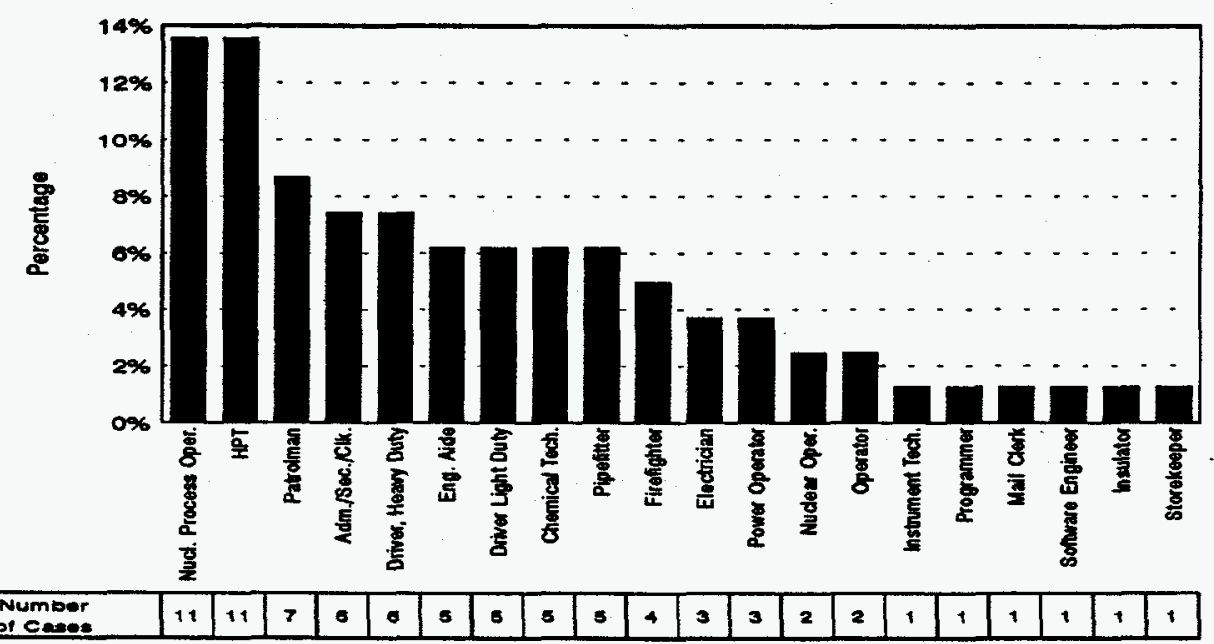




\subsubsection{Occupational Injuries/Illnesses By Facility}

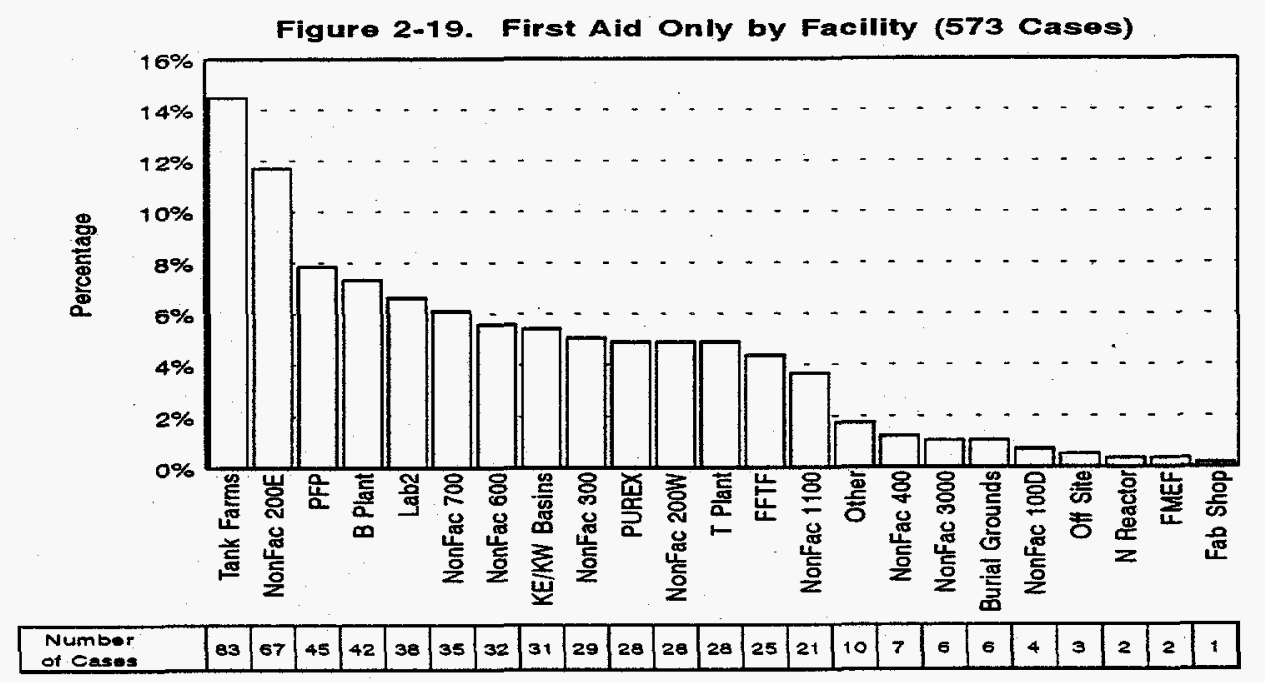

Figure 2-20. Total Recordable Injuries/llinesses by Facility (292 Cases)

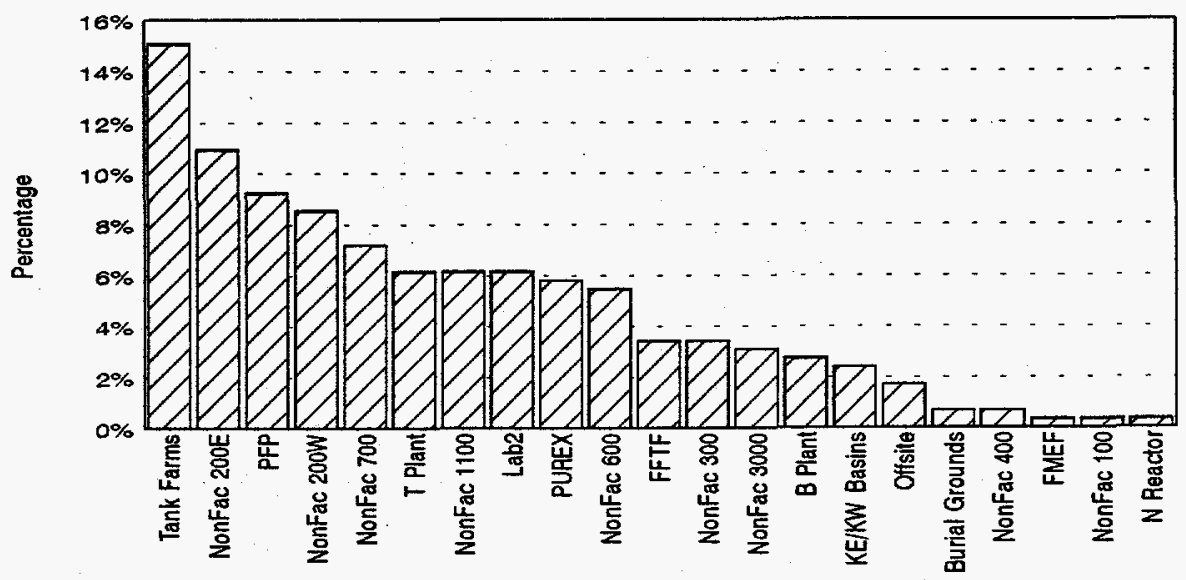

\begin{tabular}{|l|l|l|l|l|l|l|l|l|l|l|l|l|l|l|l|l|l|l|l|l|l|}
\hline $\begin{array}{l}\text { Number } \\
\text { of Cases }\end{array}$ & 44 & 32 & 27 & 25 & 21 & 18 & 18 & 18 & 17 & 16 & 10 & 10 & 9 & 8 & 7 & 5 & 2 & 2 & 1 & 1 & 1 \\
\hline
\end{tabular}

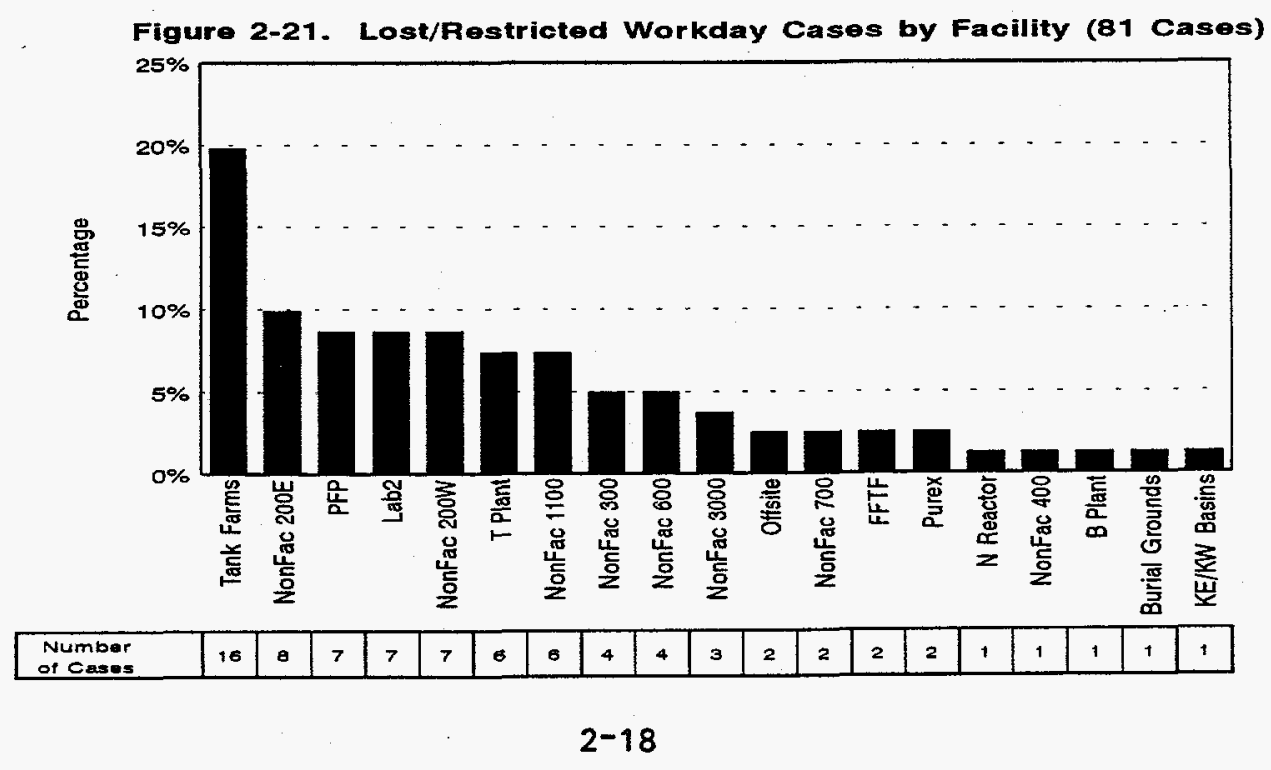




\subsubsection{Human Resources (HR)}

The numbers in Tables 2-3 and 2-4 reflect the job-related injuries/illnesses reported by HR personnel during CY 1995.

Congratulations to the HR department, for having worked over 985,000 hours without a lost workday away injury/illness! The last lost workday away case occurred on December 17, 1992.

Table 2-3. HR Occupational Injury/Illness CY 1994 - CY 1995 Statistics Comparison

\begin{tabular}{|c|c|c|c|c|}
\hline Time Period & $\begin{array}{c}\text { First Aid } \\
\text { Cases }\end{array}$ & $\begin{array}{c}\text { First Aid } \\
\text { Case Rate }\end{array}$ & $\begin{array}{c}\text { Total } \\
\text { Recordable Cases }\end{array}$ & $\begin{array}{c}\text { Total Recordable } \\
\text { Case Incidence Rate }\end{array}$ \\
\hline \hline CY 1994 & 11 & 3.71 & 0 & 0 \\
\hline CY 1995 & 3 & 1.57 & 0 & 0 \\
\hline
\end{tabular}

\begin{tabular}{|c|c|c|c|c|c|c|}
\hline Time Period & $\begin{array}{c}\text { Recordable } \\
\text { Cases } \\
\text { Resulting in } \\
\text { Lost/Restricted } \\
\text { Workdays }\end{array}$ & $\begin{array}{c}\text { Lost/ } \\
\text { Restricted } \\
\text { Workday } \\
\text { Case } \\
\text { Incidence } \\
\text { Rate }\end{array}$ & $\begin{array}{c}\text { Cases } \\
\text { Involving } \\
\text { Days Away } \\
\text { from Work }\end{array}$ & $\begin{array}{c}\text { Lost Workday } \\
\text { Away Only } \\
\text { Case Incidence } \\
\text { Rate }\end{array}$ & $\begin{array}{c}\text { Cases } \\
\text { Involving Days } \\
\text { of Restricted } \\
\text { Work Activity } \\
\text { Only }\end{array}$ & $\begin{array}{c}\text { Restricted } \\
\text { Work } \\
\text { Activity } \\
\text { Only Case } \\
\text { Incidence } \\
\text { Rate }\end{array}$ \\
\hline \hline CY 1994 & $\mathbf{0}$ & $\mathbf{0}$ & $\mathbf{0}$ & $\mathbf{0}$ & $\mathbf{0}$ & $\mathbf{0}$ \\
\hline CY 1995 & $\mathbf{0}$ & $\mathbf{0}$ & $\mathbf{0}$ & $\mathbf{0}$ & $\mathbf{0}$ & $\mathbf{0}$ \\
\hline
\end{tabular}

\begin{tabular}{|c|c|c|c|c|c|c|}
\hline Time Period & $\begin{array}{c}\text { No. of } \\
\text { Lost/ } \\
\text { Restricted } \\
\text { Workdays }\end{array}$ & $\begin{array}{c}\text { Lost/ } \\
\text { Restricted } \\
\text { Workday } \\
\text { Severity Rate }\end{array}$ & $\begin{array}{c}\text { No. of } \\
\text { Workdays } \\
\text { Away Only }\end{array}$ & $\begin{array}{c}\text { Workdays } \\
\text { Away Only } \\
\text { Severity } \\
\text { Rate }\end{array}$ & $\begin{array}{c}\text { No. of Days } \\
\text { Restricted } \\
\text { Work Activity }\end{array}$ & $\begin{array}{c}\text { Restricted } \\
\text { Work Activity } \\
\text { Severity } \\
\text { Rate }\end{array}$ \\
\hline CY 1994 & 0 & 0 & 0 & 0 & 0 & 0 \\
\hline CY 1995 & 0 & 0 & 0 & 0 & 0 & 0 \\
\hline
\end{tabular}

Table 2-4. HR Occupational Injuries/Illnesses By Type - CY 1995

\begin{tabular}{|c|c|c|c|c|}
\hline Type & $\begin{array}{c}\text { All Cases } \\
\text { (First Aid/ } \\
\text { Recordable/ } \\
\text { Lost/Restricted) }\end{array}$ & All Case Rate & $\begin{array}{c}\text { Cases Resulting } \\
\text { in Lost or } \\
\text { Restricted Workdays }\end{array}$ & $\begin{array}{c}\text { Lost or Restricted } \\
\text { Workday Case } \\
\text { Incidence Rate }\end{array}$ \\
\hline \hline All Strain/Sprain & 0 & 0 & 0 & 0 \\
\hline $\begin{array}{c}\text { Cumulative Trauma } \\
\text { Disorder }\end{array}$ & 0 & 0 & 0 & 0 \\
\hline All Other & $\mathbf{3}$ & 1.57 & 0 & 0 \\
\hline
\end{tabular}




\subsubsection{Transition Projects (TRP)}

The numbers in Tables 2-5 and 2-6 reflect the job-related injuries/illnesses reported by TRP personnel during CY 1995.

Table 2-5. TRP Occupational Injury/Illness

CY 1994 - CY 1995 Statistics Comparison

\begin{tabular}{|c|c|c|c|c|}
\hline Time Period & $\begin{array}{c}\text { First Aid } \\
\text { Cases }\end{array}$ & $\begin{array}{c}\text { First Aid } \\
\text { Case Rate }\end{array}$ & $\begin{array}{c}\text { Total } \\
\text { Recordable Cases }\end{array}$ & $\begin{array}{c}\text { Total Recordable } \\
\text { Case Incidence Rate }\end{array}$ \\
\hline \hline CY 1994 & 175 & 9.92 & 77 & 4.36 \\
\hline CY 1995 & 141 & 9.70 & 68 & 4.68 \\
\hline
\end{tabular}

\begin{tabular}{|c|c|c|c|c|c|c|}
\hline Time Period & $\begin{array}{c}\text { Recordable } \\
\text { Cases } \\
\text { Resulting in } \\
\text { Lost/Restricted } \\
\text { Workdays }\end{array}$ & $\begin{array}{c}\text { Lost/ } \\
\text { Restricted } \\
\text { Workday } \\
\text { Case } \\
\text { Incidence } \\
\text { Rate }\end{array}$ & $\begin{array}{c}\text { Cases } \\
\text { Involving } \\
\text { Days Away } \\
\text { from Work }\end{array}$ & $\begin{array}{c}\text { Lost Workday } \\
\text { Away Only } \\
\text { Case Incidence } \\
\text { Rate }\end{array}$ & $\begin{array}{c}\text { Cases } \\
\text { Involving Days } \\
\text { of Restricted } \\
\text { Work Activity } \\
\text { Only }\end{array}$ & $\begin{array}{c}\text { Restricted } \\
\text { Work } \\
\text { Activity } \\
\text { Only Case } \\
\text { Incidence } \\
\text { Rate }\end{array}$ \\
\hline \hline CY 1994 & 28 & 1.59 & 20 & 1.13 & 8 & 0.45 \\
\hline CY 1995 & 12 & 0.83 & 6 & 0.41 & 6 & 0.41 \\
\hline
\end{tabular}

\begin{tabular}{|c|c|c|c|c|c|c|}
\hline Time Period & $\begin{array}{c}\text { No. of } \\
\text { Lost/ } \\
\text { Restricted } \\
\text { Workdays }\end{array}$ & $\begin{array}{c}\text { Lost/ } \\
\text { Restricted } \\
\text { Workday } \\
\text { Severity Rate }\end{array}$ & $\begin{array}{c}\text { No. of } \\
\text { Workdays } \\
\text { Away Only }\end{array}$ & $\begin{array}{c}\text { Workdays } \\
\text { Away Only } \\
\text { Severity } \\
\text { Rate }\end{array}$ & $\begin{array}{c}\text { No. of Days } \\
\text { Restricted } \\
\text { Work Activity }\end{array}$ & $\begin{array}{c}\text { Restricted } \\
\text { Work Activity } \\
\text { Severity } \\
\text { Rate }\end{array}$ \\
\hline \hline CY 1994 & 2,020 & 114.48 & 731 & 41.43 & 1,289 & 75.05 \\
\hline CY 1995 & 141 & 9.70 & 20 & 1.38 & 121 & 8.33 \\
\hline
\end{tabular}

Table 2-6. TRP Occupational Injuries/Illnesses By Type - CY 1995

\begin{tabular}{|c|c|c|c|c|}
\hline Type & $\begin{array}{c}\text { All Cases } \\
\text { (First Aid/ } \\
\text { Recordable/ } \\
\text { Lost/Restricted) }\end{array}$ & All Case Rate & $\begin{array}{c}\text { Cases Resulting } \\
\text { in Lost or } \\
\text { Restricted Workdays }\end{array}$ & $\begin{array}{c}\text { Lost or Restricted } \\
\text { Workday Case } \\
\text { Incidence Rate }\end{array}$ \\
\hline All Strain/Sprain & 33 & 2.27 & 4 & 0.28 \\
\hline $\begin{array}{c}\text { Cumulative Trauma } \\
\text { Disorder }\end{array}$ & 13 & 0.90 & 3 & 0.21 \\
\hline All Other & 164 & 11.29 & 5 & .34 \\
\hline
\end{tabular}




\subsubsection{Spent Nuclear Fuel Project (SNF)}

The numbers in Tables 2-7 and 2-8 reflect the job-related injuries/illnesses reported by SNF personnel during CY 1995.

Table 2-7. SNF Occupational Injury/Illness

CY 1994 - CY 1995 Statisties Comparison

\begin{tabular}{|c|c|c|c|c|}
\hline Time Period & $\begin{array}{c}\text { First Aid } \\
\text { Cases }\end{array}$ & $\begin{array}{c}\text { First Aid } \\
\text { Case Rate }\end{array}$ & $\begin{array}{c}\text { Total } \\
\text { Recordable Cases }\end{array}$ & $\begin{array}{c}\text { Total Recordable } \\
\text { Case Incidence Rate }\end{array}$ \\
\hline \hline CY 1994 & 25 & 5.79 & 14 & 3.24 \\
\hline CY 1995 & 30 & 10.83 & 7 & 2.53 \\
\hline
\end{tabular}

\begin{tabular}{|c|c|c|c|c|c|c|}
\hline Time Period & $\begin{array}{c}\text { Recordable } \\
\text { Cases } \\
\text { Resulting in } \\
\text { Lost/Restricted } \\
\text { Workdays }\end{array}$ & $\begin{array}{c}\text { Lost/ } \\
\text { Restricted } \\
\text { Workday } \\
\text { Case Incidence } \\
\text { Rate }\end{array}$ & $\begin{array}{c}\text { Cases } \\
\text { Involving } \\
\text { Days Away } \\
\text { from Work }\end{array}$ & $\begin{array}{c}\text { Lost Workday } \\
\text { Away Only } \\
\text { Case Incidence } \\
\text { Rate }\end{array}$ & $\begin{array}{c}\text { Cases } \\
\text { Involving } \\
\text { Days of } \\
\text { Restricted } \\
\text { Work Activity } \\
\text { Only }\end{array}$ & $\begin{array}{c}\text { Restricted } \\
\text { Workday } \\
\text { Activity } \\
\text { Only Case } \\
\text { Incidence Rate }\end{array}$ \\
\hline \hline CY 1994 & 1 & 0.23 & 1 & 0.23 & 0 & 0 \\
\hline CY 1995 & 1 & 0.36 & 1 & 0.36 & 0 & 0 \\
\hline
\end{tabular}

\begin{tabular}{|c|c|c|c|c|c|c|}
\hline Time Period & $\begin{array}{c}\text { No. of } \\
\text { Lost/ } \\
\text { Restricted } \\
\text { Workdays }\end{array}$ & $\begin{array}{c}\text { Lost/ } \\
\text { Restricted } \\
\text { Workday } \\
\text { Severity Rate }\end{array}$ & $\begin{array}{c}\text { No. of } \\
\text { Workdays } \\
\text { Away Only }\end{array}$ & $\begin{array}{c}\text { Workdays } \\
\text { Away Only } \\
\text { Severity } \\
\text { Rate }\end{array}$ & $\begin{array}{c}\text { No. of } \\
\text { Days } \\
\text { Restricted } \\
\text { Work Activity }\end{array}$ & $\begin{array}{c}\text { Restricted } \\
\text { Work Activity } \\
\text { Severity } \\
\text { Rate }\end{array}$ \\
\hline \hline CY 1994 & 2 & 0.46 & 2 & 0.46 & 0 & 0 \\
\hline CY 1995 & 2 & 0.72 & 1 & 0.36 & 1 & 0.36 \\
\hline
\end{tabular}

Table 2-8. SNF Occupational Injuries/Illnesses By Type - CY 1995

\begin{tabular}{|c|c|c|c|c|}
\hline Type & $\begin{array}{c}\text { All Cases } \\
\text { (First Aid/ } \\
\text { Recordable/ } \\
\text { Lost/Restricted) }\end{array}$ & All Case Rate & $\begin{array}{c}\text { Cases Resulting } \\
\text { in Lost or } \\
\text { Restricted Workdays }\end{array}$ & $\begin{array}{c}\text { Lost or Restricted } \\
\text { Workday Case } \\
\text { Incidence Rate }\end{array}$ \\
\hline \hline All Strain/Sprain & 7 & 2.53 & 1 & 0.36 \\
\hline $\begin{array}{c}\text { Cumulative Trauma } \\
\text { Disorder }\end{array}$ & 0 & 0 & 0 & 0 \\
\hline All Other & 30 & 10.83 & 0 & 0 \\
\hline
\end{tabular}




\subsubsection{Emergency, Safety, Quality Services (ESQ).}

The numbers in Tables 2-9 and 2-10 reflect the job-related injuries/illnesses reported by ESQ personnel during CY 1995.

Table 2-9. ESQ Occupational Injury/IIIness

CY 1994 - CY 1995 Statistics Comparison

\begin{tabular}{|c|c|c|c|c|}
\hline Time Period & $\begin{array}{c}\text { First Aid } \\
\text { Only Cases }\end{array}$ & $\begin{array}{c}\text { First Aid } \\
\text { Case Rate }\end{array}$ & $\begin{array}{c}\text { Total } \\
\text { Recordable Cases }\end{array}$ & $\begin{array}{c}\text { Total Recordable } \\
\text { Case Incidence Rate }\end{array}$ \\
\hline \hline CY 1994 & 186 & 11.22 & 80 & 4.83 \\
\hline CY 1995 & 132 & 9.94 & 69 & 5.20 \\
\hline
\end{tabular}

\begin{tabular}{|c|c|c|c|c|c|c|}
\hline Time Period & $\begin{array}{c}\text { Recordable } \\
\text { Cases } \\
\text { Resulting in } \\
\text { Lost/Restricted } \\
\text { Workdays }\end{array}$ & $\begin{array}{c}\text { Lost/ } \\
\text { Restricted } \\
\text { Workday } \\
\text { Case } \\
\text { Incidence } \\
\text { Rate }\end{array}$ & $\begin{array}{c}\text { Cases } \\
\text { Involving } \\
\text { Days Away } \\
\text { from Work }\end{array}$ & $\begin{array}{c}\text { Lost Workday } \\
\text { Away Only } \\
\text { Case } \\
\text { Incidence } \\
\text { Rate }\end{array}$ & $\begin{array}{c}\text { Cases } \\
\text { Involving } \\
\text { Days of } \\
\text { Restricted } \\
\text { Work Activity } \\
\text { Only }\end{array}$ & $\begin{array}{c}\text { Restricted } \\
\text { Work } \\
\text { Activity } \\
\text { Only Case } \\
\text { Incidence } \\
\text { Rate }\end{array}$ \\
\hline \hline CY 1994 & 28 & 1.69 & 15 & 0.90 & 13 & 0.78 \\
\hline CY 1995 & 26 & 1.96 & 9 & 0.68 & 17 & 1.28 \\
\hline
\end{tabular}

\begin{tabular}{|c|c|c|c|c|c|c|}
\hline Time Period & $\begin{array}{c}\text { No. of } \\
\text { Lost/ } \\
\text { Restricted } \\
\text { Workdays }\end{array}$ & $\begin{array}{c}\text { Lost/ } \\
\text { Restricted } \\
\text { Workday } \\
\text { Severity Rate }\end{array}$ & $\begin{array}{c}\text { No. of } \\
\text { Workdays } \\
\text { Away Only }\end{array}$ & $\begin{array}{c}\text { Workdays } \\
\text { Away Only } \\
\text { Severity } \\
\text { Rate }\end{array}$ & $\begin{array}{c}\text { No. of } \\
\text { Days } \\
\text { Restricted } \\
\text { Work Activity }\end{array}$ & $\begin{array}{c}\text { Restricted } \\
\text { Work Activity } \\
\text { Severity } \\
\text { Rate }\end{array}$ \\
\hline \hline CY 1994 & 1,170 & 70.58 & 373 & 22.50 & 797 & 48.08 \\
\hline CY 1995 & 492 & 37.04 & 124 & 9.34 & 368 & 27.71 \\
\hline
\end{tabular}

Table 2-10. ESQ Occupational Injuries/IIlnesses By Type - CY 1995

\begin{tabular}{|c|c|c|c|c|}
\hline Type & $\begin{array}{c}\text { All Cases } \\
\text { (First Aid/ } \\
\text { Recordable/ } \\
\text { Lost/Restricted) }\end{array}$ & All Case Rate & $\begin{array}{c}\text { Cases Resulting } \\
\text { in Lost or } \\
\text { Restricted Workdays }\end{array}$ & $\begin{array}{c}\text { Lost or Restricted } \\
\text { Workday Case } \\
\text { Incidence Rate }\end{array}$ \\
\hline \hline All Strain/Sprain & 56 & 4.22 & 21 & 1.58 \\
\hline $\begin{array}{c}\text { Cumulative Trauma } \\
\text { Disorder }\end{array}$ & 8 & 0.60 & 0 & 0 \\
\hline All Other & 137 & 10.31 & 5 & 0.38 \\
\hline
\end{tabular}




\subsubsection{Chief Financial Office (CFO)}

The numbers in Tables 2-11 and 2-12 reflect the job-related injuries/illnesses reported by CFO personnel during CY 1995.

Table 2-11. CFO Occupational Injury/Illness

CY 1994 - CY 1995 Statistics Comparison

\begin{tabular}{|c|c|c|c|c|}
\hline Time Period & $\begin{array}{c}\text { First Aid } \\
\text { Cases }\end{array}$ & $\begin{array}{c}\text { First Aid } \\
\text { Case Rate }\end{array}$ & $\begin{array}{c}\text { Total } \\
\text { Recordable Cases }\end{array}$ & $\begin{array}{c}\text { Total Recordable } \\
\text { Case Incidence Rate }\end{array}$ \\
\hline \hline CY 1994 & 28 & 3.76 & 21 & 2.82 \\
\hline CY 1995 & 17 & 3.29 & 13 & 2.52 \\
\hline
\end{tabular}

\begin{tabular}{|c|c|c|c|c|c|c|}
\hline Time Period & $\begin{array}{c}\text { Recordable } \\
\text { Cases } \\
\text { Resulting in } \\
\text { Lost/Restricted } \\
\text { Workdays }\end{array}$ & $\begin{array}{c}\text { Lost/ } \\
\text { Restricted } \\
\text { Workday } \\
\text { Case } \\
\text { Incidence } \\
\text { Rate }\end{array}$ & $\begin{array}{c}\text { Cases } \\
\text { Involving } \\
\text { Days Away } \\
\text { from Work }\end{array}$ & $\begin{array}{c}\text { Lost Workday } \\
\text { Away Only } \\
\text { Case Incidence } \\
\text { Rate }\end{array}$ & $\begin{array}{c}\text { Cases } \\
\text { Involving } \\
\text { Days of } \\
\text { Restricted } \\
\text { Work Activity } \\
\text { Only }\end{array}$ & $\begin{array}{c}\text { Restricted } \\
\text { Work } \\
\text { Activity } \\
\text { Only Case } \\
\text { Incidence } \\
\text { Rate }\end{array}$ \\
\hline CY 1994 & 4 & 0.54 & 2 & 0.27 & 2 & 0.27 \\
\hline CY 1995 & 4 & 0.78 & 3 & 0.58 & 1 & 0.19 \\
\hline
\end{tabular}

\begin{tabular}{|c|c|c|c|c|c|c|}
\hline Time Period & $\begin{array}{c}\text { No. of } \\
\text { Lost/ } \\
\text { Restricted } \\
\text { Workdays }\end{array}$ & $\begin{array}{c}\text { Lost/ } \\
\text { Restricted } \\
\text { Days } \\
\text { Severity } \\
\text { Rate }\end{array}$ & $\begin{array}{c}\text { No. of } \\
\text { Workdays } \\
\text { Away Only }\end{array}$ & $\begin{array}{c}\text { Workdays } \\
\text { Away Only } \\
\text { Severity } \\
\text { Rate }\end{array}$ & $\begin{array}{c}\text { No. of } \\
\text { Days } \\
\text { Restricted } \\
\text { Work Activity }\end{array}$ & $\begin{array}{c}\text { Restricted } \\
\text { Work Activity } \\
\text { Severity } \\
\text { Rate }\end{array}$ \\
\hline \hline CY 1994 & 286 & 38.41 & 189 & 25.38 & 97 & 13.03 \\
\hline CY 1995 & 236 & 45.69 & 190 & 36.78 & 46 & 8.91 \\
\hline
\end{tabular}

Table 2-12. CFO Occupational Injuries/Ịllnesses By Type - CY 1995

\begin{tabular}{|c|c|c|c|c|}
\hline Type & $\begin{array}{c}\text { All Cases } \\
\text { (First Aid/ } \\
\text { Recordable/ } \\
\text { Lost/Restricted) }\end{array}$ & All Case Rate & $\begin{array}{c}\text { Cases Resulting } \\
\text { in Lost or } \\
\text { Restricted Workdays }\end{array}$ & $\begin{array}{c}\text { Lost or Restricted } \\
\text { Workday Case } \\
\text { Incidence Rate }\end{array}$ \\
\hline \hline All Strain/Sprain & 13 & 2.52 & 4 & 0.78 \\
\hline Cumulative Trauma Disorder & 5 & 0.97 & 0 & 0 \\
\hline All Other & 12 & 2.32 & 0 & 0 \\
\hline
\end{tabular}




\subsubsection{BCS Richland, Incorporated (BCSR).}

The numbers in Tables 2-13 and 2-14 reflect the job-related injuries/illnesses reported by BCSR personnel during CY 1995.

Table 2-13. BCSR Occupational Injury/Illness

CY 1994 - CY 1995 Statistics Comparison

\begin{tabular}{|c|c|c|c|c|}
\hline Time Period & $\begin{array}{c}\text { First Aid } \\
\text { Cases }\end{array}$ & $\begin{array}{c}\text { First Aid } \\
\text { Case Rate }\end{array}$ & $\begin{array}{c}\text { Total } \\
\text { Recordable Cases }\end{array}$ & $\begin{array}{c}\text { Total Recordable } \\
\text { Case Incidence Rate }\end{array}$ \\
\hline CY 1994 & 80 & 6.98 & 53 & 4.62 \\
\hline CY 1995 & 38 & 4.20 & 28 & 3.10 \\
\hline
\end{tabular}

\begin{tabular}{|c|c|c|c|c|c|c|}
\hline Time Period & $\begin{array}{c}\text { Recordable } \\
\text { Cases } \\
\text { Resulting in } \\
\text { Lost/Restricted } \\
\text { Workdays }\end{array}$ & $\begin{array}{c}\text { Lost/ } \\
\text { Restricted } \\
\text { Workday } \\
\text { Case } \\
\text { Incidence } \\
\text { Rate }\end{array}$ & $\begin{array}{c}\text { Cases } \\
\text { Involving } \\
\text { Days Away } \\
\text { from Work }\end{array}$ & $\begin{array}{c}\text { Lost Workday } \\
\text { Away Only } \\
\text { Case } \\
\text { Incidence } \\
\text { Rate }\end{array}$ & $\begin{array}{c}\text { Cases } \\
\text { Involving } \\
\text { Days of } \\
\text { Restricted } \\
\text { Work Activity } \\
\text { Only }\end{array}$ & $\begin{array}{c}\text { Restricted } \\
\text { Work } \\
\text { Activity } \\
\text { Only Case } \\
\text { Incidence } \\
\text { Rate }\end{array}$ \\
\hline \hline CY 1994 & 14 & 1.22 & 9 & 0.78 & 5 & 0.44 \\
\hline CY 1995 & 4 & 0.44 & 2 & 0.22 & 2 & 0.22 \\
\hline
\end{tabular}

\begin{tabular}{|c|c|c|c|c|c|c|}
\hline Time Period & $\begin{array}{c}\text { No. of } \\
\text { Lost/ } \\
\text { Restricted } \\
\text { Workdays }\end{array}$ & $\begin{array}{c}\text { Lost/ } \\
\text { Restricted } \\
\text { Workday } \\
\text { Severity Rate }\end{array}$ & $\begin{array}{c}\text { No. of } \\
\text { Workdays } \\
\text { Away Only }\end{array}$ & $\begin{array}{c}\text { Workdays } \\
\text { Away Only } \\
\text { Severity } \\
\text { Rate }\end{array}$ & $\begin{array}{c}\text { No. of } \\
\text { Days } \\
\text { Restricted } \\
\text { Work Activity }\end{array}$ & $\begin{array}{c}\text { Restricted } \\
\text { Work Activity } \\
\text { Severity } \\
\text { Rate }\end{array}$ \\
\hline \hline CY 1994 & 378 & 32.96 & 235 & 20.49 & 143 & 12.47 \\
\hline CY 1995 & 112 & 12.39 & 47 & 5.20 & 65 & 7.19 \\
\hline
\end{tabular}

Table 2-14. BCSR Occupational Injuries/Illnesses By Type - CY 1995

\begin{tabular}{|c|c|c|c|c|}
\hline Type & $\begin{array}{c}\text { All Cases } \\
\text { (First Aid/ } \\
\text { Recordable/ } \\
\text { Lost/Restricted) }\end{array}$ & All Case Rate & $\begin{array}{c}\text { Cases Resulting } \\
\text { in Lost or } \\
\text { Restricted Workdays }\end{array}$ & $\begin{array}{c}\text { Lost or Restricted } \\
\text { Workday Case } \\
\text { Incidence Rate }\end{array}$ \\
\hline \hline All Strain/Sprain & 12 & 1.33 & 1 & 0.11 \\
\hline Cumulative Trauma Disorder & 15 & 1.66 & 2 & 0.22 \\
\hline All Other & 28 & 3.10 & 1 & 0.11 \\
\hline
\end{tabular}




\subsubsection{Tank Waste Remediation System.}

The numbers in Tables 2-15 and 2-16 reflect the job-related injuries/illnesses reported by TWRS personnel during CY 1995.

Table 2-15. TWRS Occupational Injury/Illness

CY 1994 - CY 1995 Statistics Comparison

\begin{tabular}{|c|c|c|c|c|}
\hline Time Period & $\begin{array}{c}\text { First Aid } \\
\text { Cases }\end{array}$ & $\begin{array}{c}\text { First Aid } \\
\text { Case Rate }\end{array}$ & $\begin{array}{c}\text { Total } \\
\text { Recordable Cases }\end{array}$ & $\begin{array}{c}\text { Total Recordable } \\
\text { Case Incidence Rate }\end{array}$ \\
\hline \hline CY 1994 & 115 & 6.96 & 54 & 3.27 \\
\hline CY 1995 & 119 & 7.23 & 56 & 3.40 \\
\hline
\end{tabular}

\begin{tabular}{|c|c|c|c|c|c|c|}
\hline Time Period & $\begin{array}{c}\text { Recordable Cases } \\
\text { Resulting in } \\
\text { Lost/Restricted } \\
\text { Workdays }\end{array}$ & $\begin{array}{c}\text { Lost/ } \\
\text { Restricted } \\
\text { Workday } \\
\text { Case } \\
\text { Incidence } \\
\text { Rate }\end{array}$ & $\begin{array}{c}\text { Cases } \\
\text { Involving } \\
\text { Days Away } \\
\text { from Work }\end{array}$ & $\begin{array}{c}\text { Lost } \\
\text { Workday } \\
\text { Away Only } \\
\text { Case } \\
\text { Incidence } \\
\text { Rate }\end{array}$ & $\begin{array}{c}\text { Cases } \\
\text { Involving } \\
\text { Days of } \\
\text { Restricted } \\
\text { Work Activity } \\
\text { Only }\end{array}$ & $\begin{array}{c}\text { Restricted } \\
\text { Work } \\
\text { Activity } \\
\text { Only Case } \\
\text { Incidence } \\
\text { Rate }\end{array}$ \\
\hline \hline CY 1994 & 15 & 0.91 & 9 & 0.54 & 6 & 0.36 \\
\hline CY 1995 & 17 & 1.03 & 8 & 0.49 & 9 & 0.55 \\
\hline
\end{tabular}

\begin{tabular}{|c|c|c|c|c|c|c|}
\hline Time Period & $\begin{array}{c}\text { No. of } \\
\text { Lost/ } \\
\text { Restricted } \\
\text { Workdays }\end{array}$ & $\begin{array}{c}\text { Lost/ } \\
\text { Restricted } \\
\text { Workday } \\
\text { Severity } \\
\text { Rate }\end{array}$ & $\begin{array}{c}\text { No. of } \\
\text { Workdays } \\
\text { Away Only }\end{array}$ & $\begin{array}{c}\text { Workdays } \\
\text { Away Only } \\
\text { Severity } \\
\text { Rate }\end{array}$ & $\begin{array}{c}\text { No. of Days } \\
\text { Restricted } \\
\text { Work Activity }\end{array}$ & $\begin{array}{c}\text { Restricted } \\
\text { Work Activity } \\
\text { Severity } \\
\text { Rate }\end{array}$ \\
\hline \hline CY 1994 & 319 & 19.32 & 82 & 4.97 & 237 & 14.35 \\
\hline CY 1995 & 379 & 23.02 & 117 & 7.11 & 262 & 15.91 \\
\hline
\end{tabular}

Table 2-16. TWRS Occupational Injuries/Illnesses By Type - CY 1995

\begin{tabular}{|c|c|c|c|c|}
\hline Type & $\begin{array}{c}\text { All Cases } \\
\text { (First Aid/ } \\
\text { Recordable/ } \\
\text { Lost/Restricted) }\end{array}$ & All Case Rate & $\begin{array}{c}\text { Cases Resulting } \\
\text { in Lost or } \\
\text { Restricted Workdays }\end{array}$ & $\begin{array}{c}\text { Lost or Restricted } \\
\text { Workday Case } \\
\text { Incidence Rate }\end{array}$ \\
\hline \hline All Strain/Sprain & 37 & 2.25 & 11 & 0.67 \\
\hline Cumulative Trauma Disorder & 6 & 0.37 & 0 & 0 \\
\hline All Other & 132 & 8.02 & 6 & 0.37 \\
\hline
\end{tabular}




\subsubsection{Projects Site Services (PSS)}

The numbers in Tables 2-17 and 2-18 reflect the job-related injuries/illnesses reported by PSS personnel during CY 1995.

Table 2-17. PSS Occupational Injury/Iliness

CY 1994 - CY 1995 Statistics Comparison

\begin{tabular}{|c|c|c|c|c|}
\hline Time Period & $\begin{array}{c}\text { First Aid } \\
\text { Cases }\end{array}$ & $\begin{array}{c}\text { First Aid } \\
\text { Case Rate }\end{array}$ & $\begin{array}{c}\text { Total } \\
\text { Recordable Cases }\end{array}$ & Tatal Recordable \\
Case Incidence Rate
\end{tabular}

\begin{tabular}{|c|c|c|c|c|c|c|}
\hline Time Period & $\begin{array}{c}\text { Recordable } \\
\text { Cases } \\
\text { Resulting in } \\
\text { Lost/Restricted } \\
\text { Workdays }\end{array}$ & $\begin{array}{c}\text { Lost/ } \\
\text { Restricted } \\
\text { Workday } \\
\text { Case } \\
\text { Incidence } \\
\text { Rate }\end{array}$ & $\begin{array}{c}\text { Cases } \\
\text { Involving } \\
\text { Days Away } \\
\text { from Work }\end{array}$ & $\begin{array}{c}\text { Lost } \\
\text { Workday } \\
\text { Away Only } \\
\text { Case } \\
\text { Incidence } \\
\text { Rate }\end{array}$ & $\begin{array}{c}\text { Cases } \\
\text { Involving } \\
\text { Days of } \\
\text { Restricted } \\
\text { Work Activity } \\
\text { Only }\end{array}$ & $\begin{array}{c}\text { Restricted } \\
\text { Work } \\
\text { Activity } \\
\text { Only Case } \\
\text { Incidence Rate }\end{array}$ \\
\hline \hline CY 1994 & 17 & 1.09 & 11 & 0.70 & 6 & 0.38 \\
\hline CY 1995 & 7 & 0.79 & 0 & 0 & 7 & 0.79 \\
\hline
\end{tabular}

\begin{tabular}{|c|c|c|c|c|c|c|}
\hline Time Period & $\begin{array}{c}\text { No. of } \\
\text { Lost/ } \\
\text { Restricted } \\
\text { Workdays }\end{array}$ & $\begin{array}{c}\text { Lost/ } \\
\text { Restricted } \\
\text { Workday } \\
\text { Severity Rate }\end{array}$ & $\begin{array}{c}\text { No. of } \\
\text { Workdays } \\
\text { Away Only }\end{array}$ & $\begin{array}{c}\text { Workdays } \\
\text { Away Only } \\
\text { Severity } \\
\text { Rate }\end{array}$ & $\begin{array}{c}\text { No. of } \\
\text { Days } \\
\text { Restricted } \\
\text { Work Activity }\end{array}$ & $\begin{array}{c}\text { Restricted } \\
\text { Work Activity } \\
\text { Severity } \\
\text { Rate }\end{array}$ \\
\hline \hline CY 1994 & 433 & 27.64 & 153 & 9.77 & 280 & 17.87 \\
\hline CY 1995 & 155 & 17.38 & 0 & 0 & 155 & 17.38 \\
\hline
\end{tabular}

Table 2-18. PSS Occupational Injuries/Illnesses By Type - CY 1995

\begin{tabular}{|c|c|c|c|c|}
\hline Type & $\begin{array}{c}\text { All Cases } \\
\text { (First Aid/ } \\
\text { Recordable/ } \\
\text { Lost/Restricted) }\end{array}$ & All Case Rate & $\begin{array}{c}\text { Cases Resulting } \\
\text { in Lost or } \\
\text { Restricted Workdays }\end{array}$ & $\begin{array}{c}\text { Lost or Restricted } \\
\text { Workday Case } \\
\text { Incidence Rate }\end{array}$ \\
\hline \hline All Strain/Sprain & 16 & 1.80 & 2 & 0.23 \\
\hline Cumulative Trauma Disorder & 6 & .67 & 1 & 0.11 \\
\hline All Other & 56 & 6.28 & 1 & 0.17 \\
\hline
\end{tabular}




\subsubsection{Solid Waste Disposal (SWD)}

The numbers in Tables 2-19 and 2-20 reflect the job-related injuries/illnesses reported by SWD personnel during CY 1995.

Table 2-19. SWD Occupational Injury/Illness

CY 1994 - CY 1995 Statistics Comparison

\begin{tabular}{|c|c|c|c|c|}
\hline Time Period & $\begin{array}{c}\text { First Aid } \\
\text { Cases }\end{array}$ & $\begin{array}{c}\text { First Aid } \\
\text { Case Rate }\end{array}$ & $\begin{array}{c}\text { Total } \\
\text { Recordable Cases }\end{array}$ & $\begin{array}{c}\text { Total Recordable } \\
\text { Case Incidence Rate }\end{array}$ \\
\hline \hline CY 1994 & 44 & 11.85 & 22 & 5.93 \\
\hline CY 1995 & 30 & 8.68 & 20 & 5.78 \\
\hline
\end{tabular}

\begin{tabular}{|c|c|c|c|c|c|c|}
\hline Time Period & $\begin{array}{c}\text { Recordable } \\
\text { Cases } \\
\text { Resulting in } \\
\text { Lost/Restricted } \\
\text { Workdays }\end{array}$ & $\begin{array}{c}\text { Lost/ } \\
\text { Restricted } \\
\text { Workday } \\
\text { Case } \\
\text { Incidence } \\
\text { Rate }\end{array}$ & $\begin{array}{c}\text { Cases } \\
\text { Involving } \\
\text { Days Away } \\
\text { from Work }\end{array}$ & $\begin{array}{c}\text { Lost } \\
\text { Workday } \\
\text { Away Only } \\
\text { Case } \\
\text { Incidence } \\
\text { Rate }\end{array}$ & $\begin{array}{c}\text { Cases } \\
\text { Involving } \\
\text { Days of } \\
\text { Restricted } \\
\text { Work Activity } \\
\text { Only }\end{array}$ & $\begin{array}{c}\text { Restricted } \\
\text { Work } \\
\text { Activity } \\
\text { Only Case } \\
\text { Incidence Rate }\end{array}$ \\
\hline \hline CY 1994 & 8 & 2.15 & 4 & 1.08 & 4 & 1.08 \\
\hline CY 1995 & 6 & 1.74 & 1 & 0.29 & 5 & 1.45 \\
\hline
\end{tabular}

\begin{tabular}{|c|c|c|c|c|c|c|}
\hline Time Period & $\begin{array}{c}\text { No. of } \\
\text { Lost/ } \\
\text { Restricted } \\
\text { Workdays }\end{array}$ & $\begin{array}{c}\text { Lost/ } \\
\text { Restricted } \\
\text { Workday } \\
\text { Severity Rate }\end{array}$ & $\begin{array}{c}\text { No. of } \\
\text { Workdays } \\
\text { Away Only }\end{array}$ & $\begin{array}{c}\text { Workdays } \\
\text { Away Only } \\
\text { Severity } \\
\text { Rate }\end{array}$ & $\begin{array}{c}\text { No. of } \\
\text { Days } \\
\text { Restricted } \\
\text { Work Activity }\end{array}$ & $\begin{array}{c}\text { Restricted } \\
\text { Work Activity } \\
\text { Severity } \\
\text { Rate }\end{array}$ \\
\hline \hline CY 1994 & 186 & 50.10 & 44 & 11.85 & 142 & 38.25 \\
\hline CY 1995 & 67 & 19.38 & 3 & 0.87 & 64 & 18.51 \\
\hline
\end{tabular}

Table 2-20. SWD Occupational Injuries/Illnesses By Type - CY 1995

\begin{tabular}{|c|c|c|c|c|}
\hline Type & $\begin{array}{c}\text { All Cases } \\
\text { (First Aid/ } \\
\text { Recordable/ } \\
\text { Lost/Restricted) }\end{array}$ & All Case Rate & $\begin{array}{c}\text { Cases Resulting } \\
\text { in Lost or } \\
\text { Restricted Workdays }\end{array}$ & $\begin{array}{c}\text { Lost or Restricted } \\
\text { Workday Case } \\
\text { Incidence Rate }\end{array}$ \\
\hline \hline All Strain/Sprain & 17 & 4.92 & 3 & 0.87 \\
\hline Cumulative Trauma Disorder & 4 & 1.16 & 2 & 0.58 \\
\hline All Other & 29 & 8.39 & 1 & 0.29 \\
\hline
\end{tabular}




\subsubsection{ICF Kaiser Hanford Company (ICF KH) Lost/Restricted Workday Cases/Rates By DOE Computerized Accident/Incident Reporting (CAIRS) Organization}

The ICF KH cumulative CY 1995 lost/restricted workday case rate (3.15) is 22 percent below the company's 3 year average (4.05) (Figure 2-22).

The ICF KH cumulative CY 1995 first half lost/restricted workday incidence (severity) rate (81.08) is 32 percent below the company's 3 year average (118.45) (Figure 2-23).

Figure 2-22. ICF KH Occupational Injury/lilinese Lost/Restricted Workday CASE Rates - CY 1995

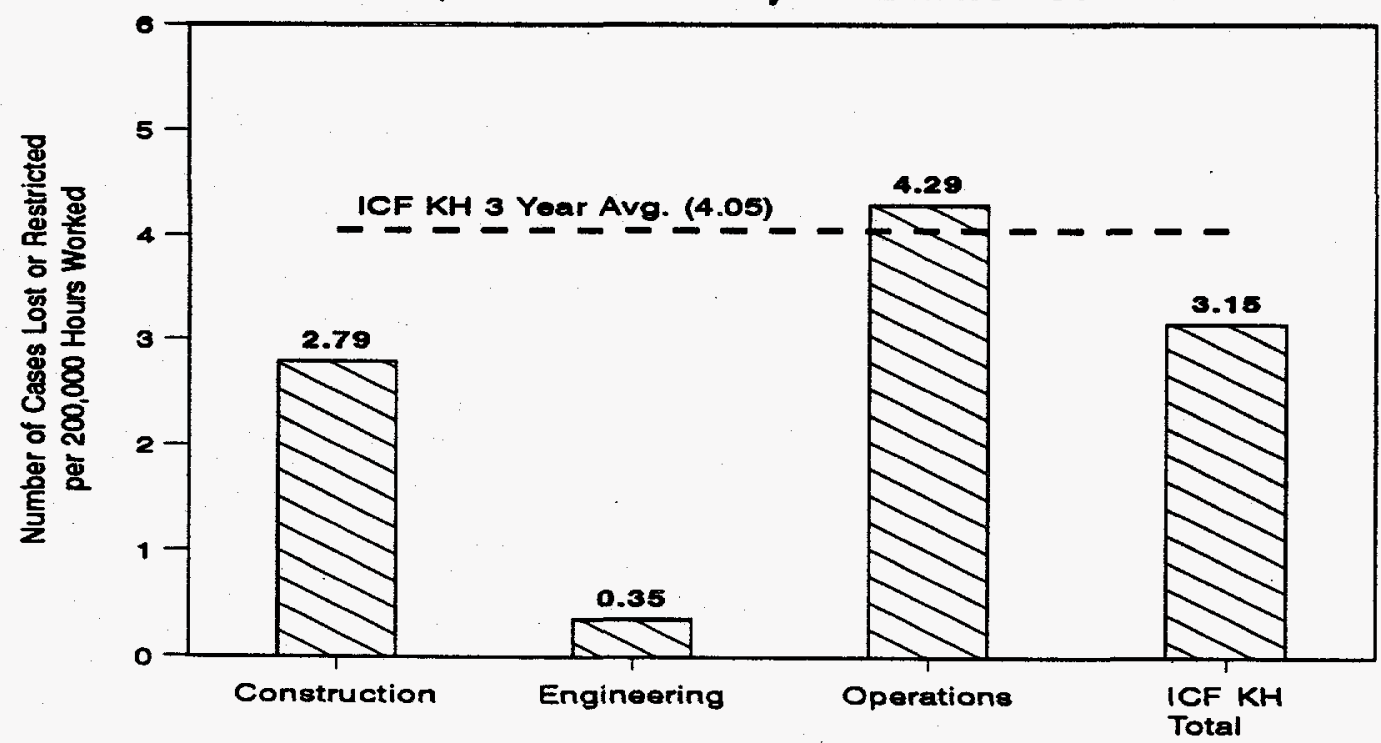

Figure 2-23. ICF KH Occupational Injury/liliness Lost/Restricted WORKDAY Incidence Rates - CY 1995

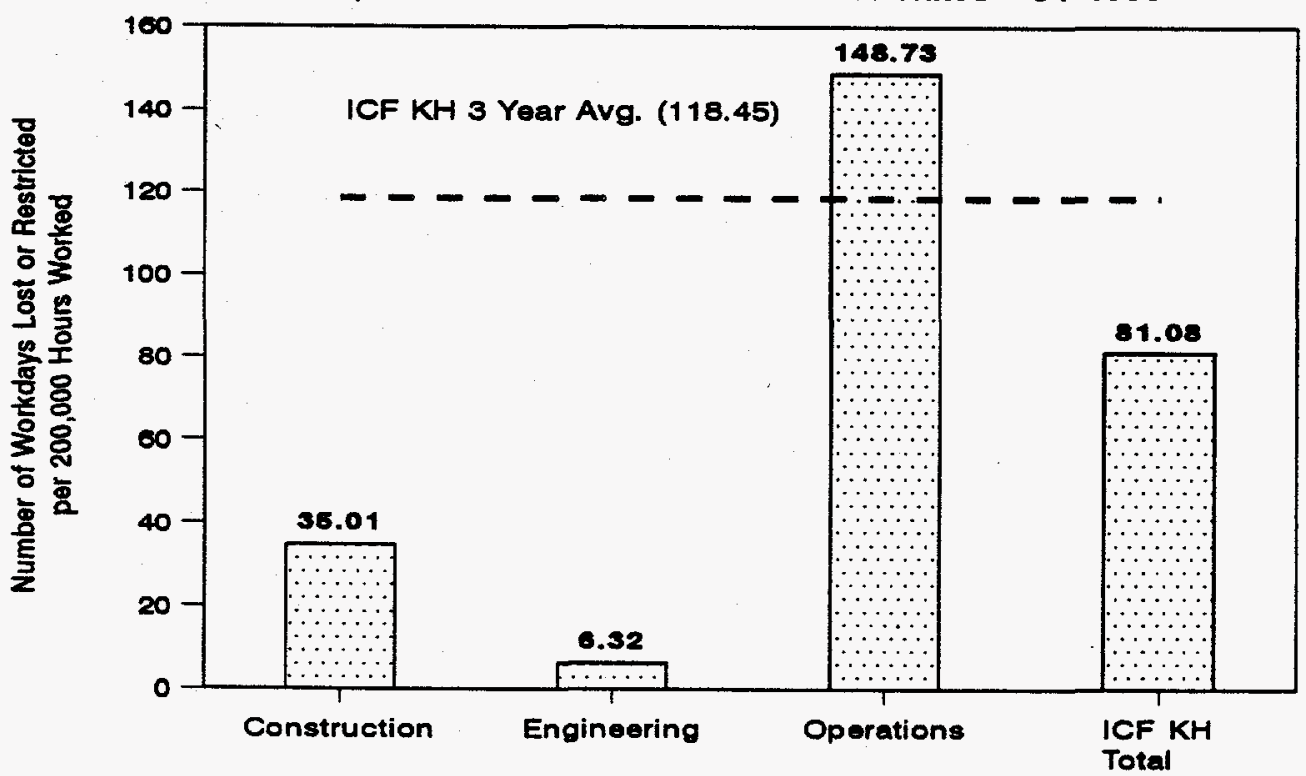




\subsubsection{WHC Recordable Government Motor Vehicle Accidents}

There were 18 recordable government vehicle accidents (resulting in $\$ 500$ damage or greater) reported by WHC employees during CY 1995, as compared to 12 recordable vehicle accidents for the same time period in CY 1994. The WHC CY 1995 recordable government vehicle accident rate is 3.79, which is above the company's CY 1994 (1.84), and also above the DOE CY 1991-93 average of 2.60 .

The WHC CY 1995 recordable government vehicle dollar loss rate (from the recordable vehicle accidents) is 13.88 (\$25,000 damage to Diesel Exhaust Fan Duct Support Structure), which is significantly above the company's CY 1994 (2.70) and also above DOE CY 1991-93 average of 4.17.

Tables 2-21 and 2-22 provide a breakdown of the recordable government vehicle accidents by organization, and type of accident. Refer to Appendix B-2 for a complete description of the Calendar Year losses.

Table 2-21. WHC CY 1995 - Recordable Vehicle Accidents By Organization

\begin{tabular}{|c|l|c|c|}
\hline $\begin{array}{c}\text { Organization } \\
\text { Code }\end{array}$ & \multicolumn{1}{|c|}{ Organization } & $\begin{array}{c}\text { Number of } \\
\text { Losses }\end{array}$ & $\begin{array}{c}\text { Total } \\
\text { Dollar Loss }\end{array}$ \\
\hline \hline 01 & Special Projects & 1 & $\$ 714$ \\
\hline OM & Environmental Monitoring & 1 & $\$ 1,384$ \\
\hline 2A & K Basins & 1 & $\$ 1,312$ \\
\hline 2C & Engineering \& Systems Integration & 1 & $\$ 7,420$ \\
\hline 33 & Radiological Control & 1 & $\$ 5,527$ \\
\hline 36 & ESQ Program Management & 1 & $\$ 975$ \\
\hline $3 B$ & Safeguards and Security & 3 & $\$ 11,893$ \\
\hline $3 \mathrm{C}$ & Hanford Fire Department & 3 & $\$ 6,098$ \\
\hline 43 & Procurement/Materials Management & 2 & $\$ 25,604$ \\
\hline 4C & Economic Transition & 1 & $\$ 2,123$ \\
\hline 7C & Tank Waste Remediation Operations Support & 2 & $\$ 2,343$ \\
\hline 8A & Process Engineering & 1 & $\$ 596$ \\
\hline \hline
\end{tabular}

Table 2-22. WHC CY 1995 - Recordable Vehicle Accidents By Cause of Accident

\begin{tabular}{|c|c|c|}
\hline Cause of Accident & Number of Losses & Total Dollar Loss \\
\hline \hline Operator Error-Backing & 8 & $\$ 39,192$ \\
\hline Operator Error-Clearance & 5 & $\$ 4,466$ \\
\hline Operator Error-Other & 4 & $\$ 21,356$ \\
\hline Non-Operator Error & 1 & $\$ 975$ \\
\hline \hline WHC Total & $\mathbf{1 8}$ & $\$ 65,989$ \\
\hline
\end{tabular}


WHC-SP-0564-40

This page is intentionally left blank. 
WHC-SP-0564-40

\subsection{RADIOLOGICAL SAFETY}

Radiological health and safety of the WHC and ICF KH workforce is ensured through the development and effective implementation of the radiological control program. Occupational radiation safety is the primary focus of the WHC Radiological Control Program. This section provides management with a perspective on performance of the Radiological Control organization in implementing processes that seek individual and collective doses to levels ALARA.

\subsection{RADIOLOGICAL CONTROL PROGRAM PERFORMANCE}

In this section, key performance trends and program accomplishments throughout the fourth quarter of CY 1995 are discussed.

\subsubsection{Key Performance Trends}

Performance data for this reporting period reflects improvements in most areas for the WHC Radiological Control (RadCon) Program. The Environmental Safety and Health compliance and customer performance area continues to be good due to open interactions and communications with $\mathrm{RL}$ in several RadCon Program areas. This is primarily led by activities that positioned WHC into full documented compliance with 10 CFR 835 and continued incremental gains in reengineering activities to improve RadCon efficiency.

\subsubsection{Program Accomplishments}

December marked the end of a year-long effort to achieve full documented compliance with all 234 requirements of the rule on Occupational Radiation Protection, 10 CFR 835. During the initial 10 CFR 835 compliance assessment conducted in November 1994, WHC claimed compliance with a third of the rule. Over the last 12 months, WHC has completed approximately 1000 Radiation Protection Program milestones on or ahead of schedule in order to achieve full compliance by the required date of January 1, 1996. Compliance with each requirement of 10 CFR 835 was documented through program content validations and field implementation verifications.

Compliance packages were submitted for nineteen separate WHC facilities/activities and for each central RadCon program which encompassed; radiological control training, records, ALARA, dosimetry, procedures, health physics technology (instruments and release), and program control and integration. Compliance was also documented for those requirements implemented either in whole, or in part, by Pacific Northwest National Laboratories (PNNL) and ICF Kaiser Hanford. This tremendous accomplishment would not have been possible without support and teamwork from both radiological control and operations. The WHC must now take on the challenge of maintaining compliance with 10 CFR 835.

During this reporting period, the WHC commissioned an "Operational Excellence Review Team" to review WHC plans to achieve radiological operational excellence and to provide WHC with an assessment and recommendations. The team was comprised of five national experts in the field of. Radiological Control who conducted their onsite review from November 8 through November 16, 
1995. The review consisted of interviews and discussions with management and staff at all levels in WHC and key positions within DOE-RL. The team performed tours of six plant facilities, observed facility activities, and interviewed plant personnel. In addition, WHC and DOE-RL assessment documentation and WHC improvement plans were reviewed.

The principal areas of comments and recommendations received involve the setting of performance standards and expectations, examination of several behavior-related incidents, the professionalism and technical competency in WHC Radiological Control operations and support, several elements related to WHC Reengineering initiatives, and surrounding them all, the collective impact of destabilizing factors on the behavior of management and the work force and their ability to stay the course of continuous improvement.

The team also identified many significant achievements that have been accomplished at WHC during the past few years. Of particular note are the progress and improvements in several of the facilities being transitioned to shutdown and improvements in the management of solid waste and tank farm activities. Further, positive results were apparent in areas that include implementing the DOE Radiological Control Manual, continued incremental gains in establishing integrated planning and scheduling systems and improving tracking/trending systems. In conclusion, the team found no conditions which would indicate the need to suspend radiological work or operations at WHC.

On January 29, 1996, the WHC RadCon organization will implement reenginered work processes and a new structure to support what is called a Radcon Center of Expertise (COE). The current positions in the central RadCon organization will be replaced by a set of newly defined positions.

On December 15, 1995, senior WHC management, with the concurrence of the RadCon reengineering team, opened the candidacy pool company wide for the new positions to enable WHC to place the most qualified individual in the right job and to provide maximum opportunities for employees. A special staff placement process is being used to fill these reengineered openings. This process enables qualified individuals to apply for the openings, but also allows managers to keep critically needed individuals in their existing positions.

A total of 29 exempt positions, including two senior management positions, were listed in a special edition of the Career Opportunities Bulletin. The new positions will require skills beyond technical capabilities; teamwork, judgement, leadership and initiative will be an important part of the selection criteria.

The radiological instrumentation cognizant engineers successfully implemented national standards for increasing the calibration interval of radiological survey instruments. This significant accomplishment has resulted in Hanford increasing the calibration intervals for portable survey instruments and personnel survey devices. These extended instrument service intervals provide a substantial cost savings without any adverse effects on worker safety. 


\subsection{EXTERNAL DOSIMETRY}

The protection of worker health and safety is of paramount concern within WHC. Since the Hanford Site is one of the largest nuclear sites in the nation, radiation safety is a key element in the protection program. The measurement of accumulated annual dose provides an indicator of the effectiveness of WHC radiation work practices and the ALARA Program with consideration given to fluctuating operating activities. Internal dose has only been included where noted in the whole body data reported in this section. It has been excluded for comparison purposes; previous year's data does not include internal dose. There has been 0.565 man rem committed effective dose equivalent (CEDE) assigned for CY 1995 from internal depositions.

\subsubsection{Occupational Collective Dose}

Record dose reflected in this report is for period ending December 31, 1995. Numbers reflect data available from the Radiological Exposure (REX) system on February 13, 1996.

3.2.1.1 Cumulative Annual Occupational Collective Dose. The Figure 3-2-1 chart data includes WHC, BCSR, and ICF KH employee exposure. The year-end results represent the exposure of 2,017 quarterly-badged employees, an average of 850 monthly-badged employees, and 4,838 annually badged employees. Radiological work increased during CY 1995 which is reflected in the higher exposure totals. This increase is mainly attributed to characterization work, and ICF KH work at C-106 and in the 300 Area for PNL.

Figure 3-2-1. Monthly, Quarterly \& Annual Exchange Dosimeter Results

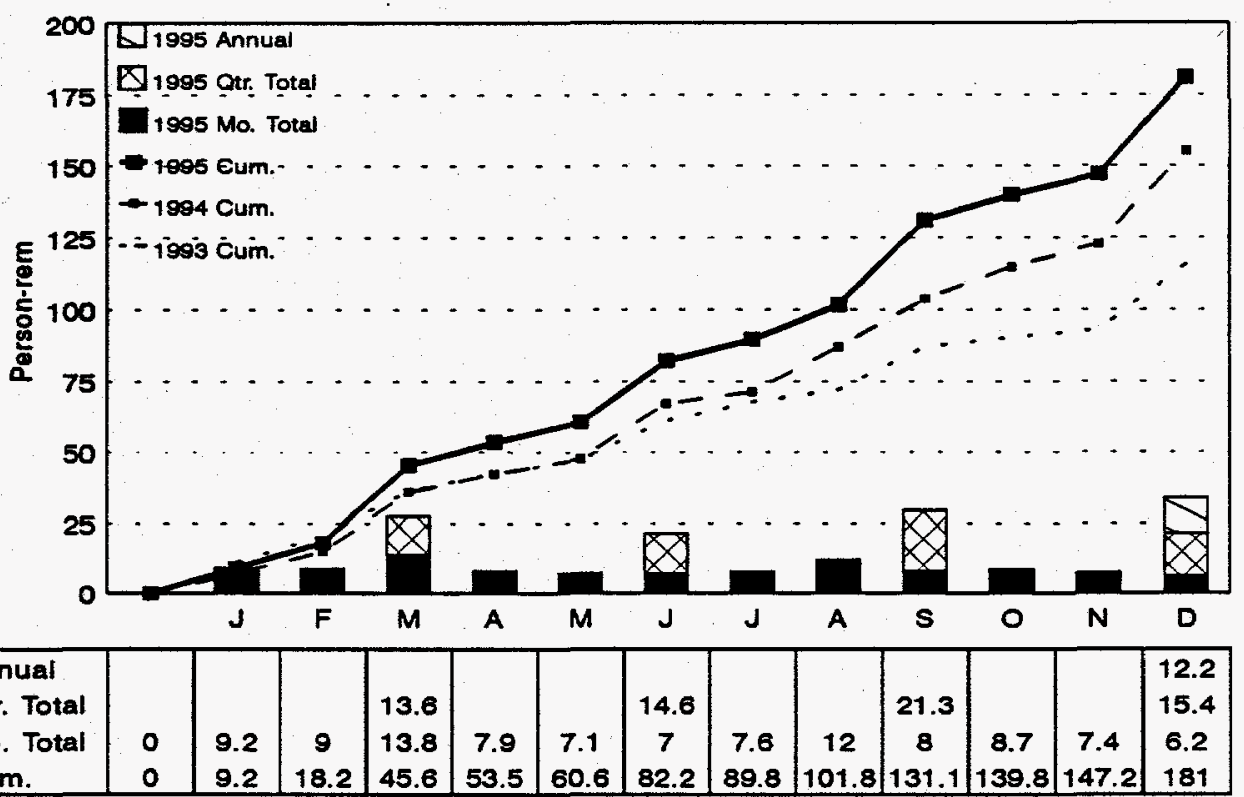

3.2.1.2 Individual Radiation Dose. The cumulative average dose in mrem for monthly badged personnel for CY 1987 through September 1995 is depicted in Figure 3-2-2. The average dose is 111 mrem for this year. This increase is primarily caused by moving approximately 200 lower-exposed workers from monthly to quarterly frequency badges. The total dose varied only 28 man rem: 153 man rem in CY 1994 to 181 man rem in CY 1995. 
Figure 3-2-2. Monthly Badged Employee Average Radiation Dose

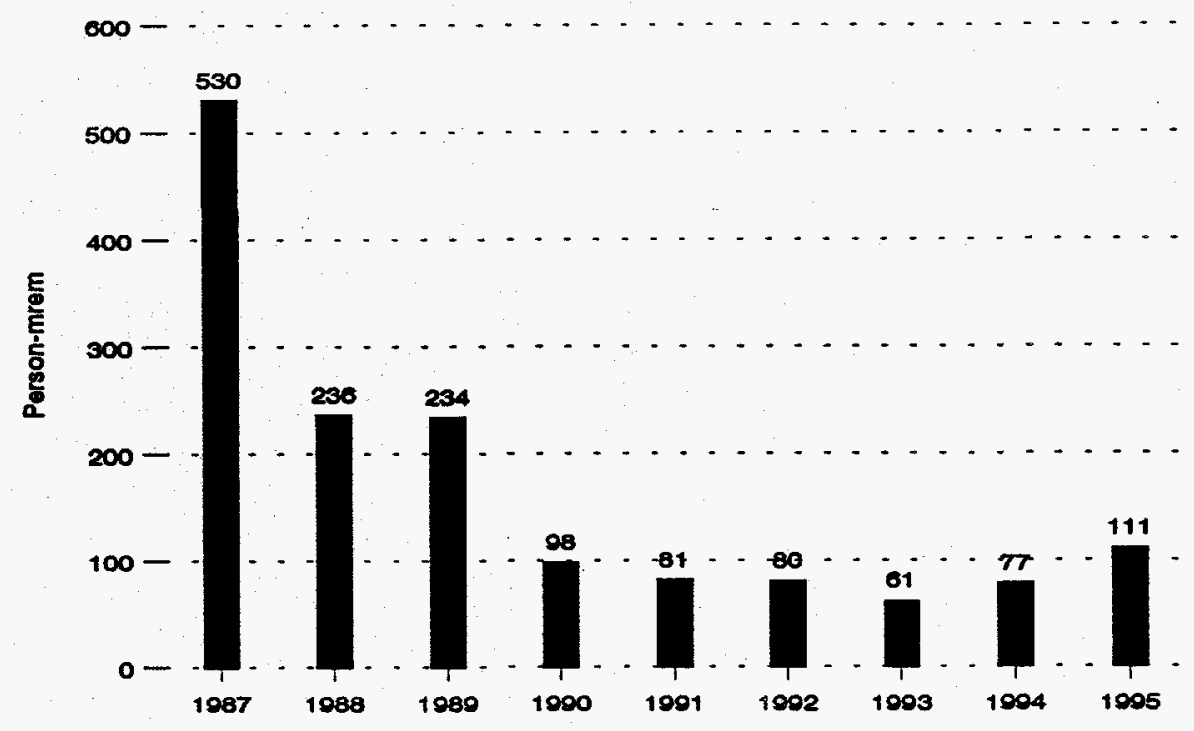

\subsubsection{High Whole Body Dose Evaluation}

Figure 3-2-3 illustrates whole body dose distribution, received onsite, among all WHC, BCSR, and ICF KH monthly frequency badged employees. Table 3-2-1 lists workers having the highest whole-body doses received onsite, during CY 1995, for both monthly and quarterly frequency badged employees.

During the fourth quarter there were no unplanned exposures resulting in a dose greater than the administrative control level of $500 \mathrm{mrem} /$ year. A total of two was recorded for the year: On $8 / 3 / 95$, a stabilization operator exceeded the control level while installing the BY-105 salt well pump; on $9 / 12 / 95$, the results of the regular dosimeter exchange determined that an ICF KH construction laborer had exceeded the control level.

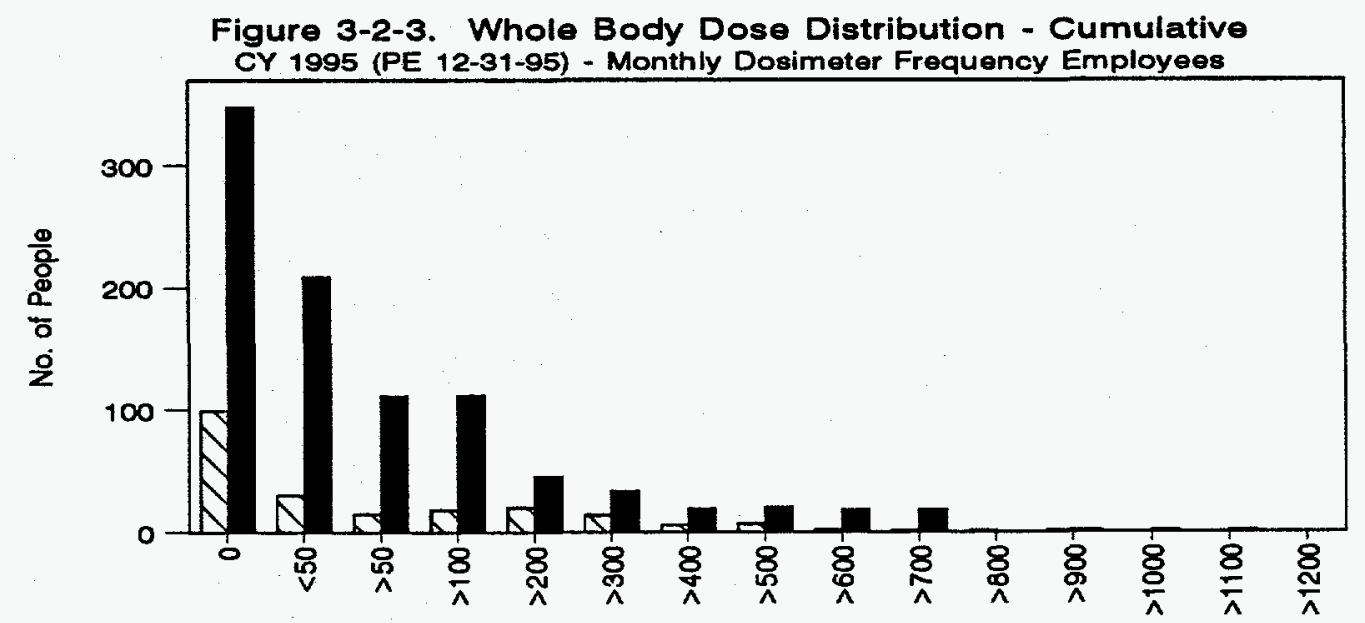

\begin{tabular}{|l|c|c|c|c|c|c|c|c|c|c|c|c|c|c|c|}
\hline ICF KH MO. $\triangle$ & 99 & 30 & 15 & 18 & 20 & 14 & 6 & 7 & 2 & 1 & 1 & 1 & 0 & 0 & 0 \\
ICF KH Otr. & 514 & 118 & 33 & 30 & 14 & 6 & 7 & 3 & 0 & 4 & 4 & 1 & 0 & 0 & 0 \\
WHC MO. & 347 & 209 & 111 & 112 & 45 & 33 & 19 & 20 & 18 & 18 & 0 & 1 & 1 & 1 & 0 \\
WHC Otr. & 1526 & 363 & 109 & 77 & 25 & 6 & 2 & 0 & 0 & 0 & 0 & 0 & 0 & 0 & 0 \\
\hline
\end{tabular}

Dose Interval - mrem 
Table 3-2-1. Highest Monthly and Quarterly Frequency Whole Body Dose Employees (Includes internal dose)

\begin{tabular}{|c|c|c|c|c|c|}
\hline Craft & $\begin{array}{l}\text { Whole } \\
\text { Body } \\
\text { (mrem) }\end{array}$ & $\begin{array}{l}\text { Organization } \\
\text { Code }\end{array}$ & Craft & $\begin{array}{l}\text { Whole } \\
\text { Body } \\
\text { (mrem) }\end{array}$ & $\begin{array}{l}\text { Organization } \\
\text { Code }\end{array}$ \\
\hline Scientist & 1106 & $15 \mathrm{~F} 00$ & Laborer & 775 & $5 \mathrm{A305}$ \\
\hline Manager/Administrator & 1069 & 15370 & Laborer & 762 & $5 A 305$ \\
\hline Engineering Technician & 984 & 15370 & Plant/Utility Operator & 756 & $2 A 430$ \\
\hline Repair/Construction & 904 & $5 \overline{B 201}$ & Laborer & 750 & $5 A 305$ \\
\hline Laborer & 828 & 5B201 & Plant/Utility Operator & 740 & 77410 \\
\hline Laborer & 790 & $2 A 430$ & Laborer & 738 & 5B201 \\
\hline Manager/Administrator & 786 & 77410 & $\overline{\text { Laborer }}$ & 735 & 5B201 \\
\hline Plant/Utility Operator & 786 & 15900 & Repair/Construction & 730 & 5F00A \\
\hline Manager/Administrator & 776 & 77410 & Plant/Utility Operator & 728 & $2 \mathrm{~A} 450$ \\
\hline Laborer & 776 & $5 \mathrm{~A} 305$ & Laborer & 724 & $5 \mathrm{~A} 305$ \\
\hline
\end{tabular}

\subsubsection{High Neutron Dose}

Figure 3-2-4 provides a 12-month rolling window of the highest monthly neutron doses received onsite. The highest neutron doses are typically recorded for employees at PFP. The highest yearly individual neutron dose received for CY 1995 was 861 mrem.

Figure 3-2-4. Highest Neutron Dose

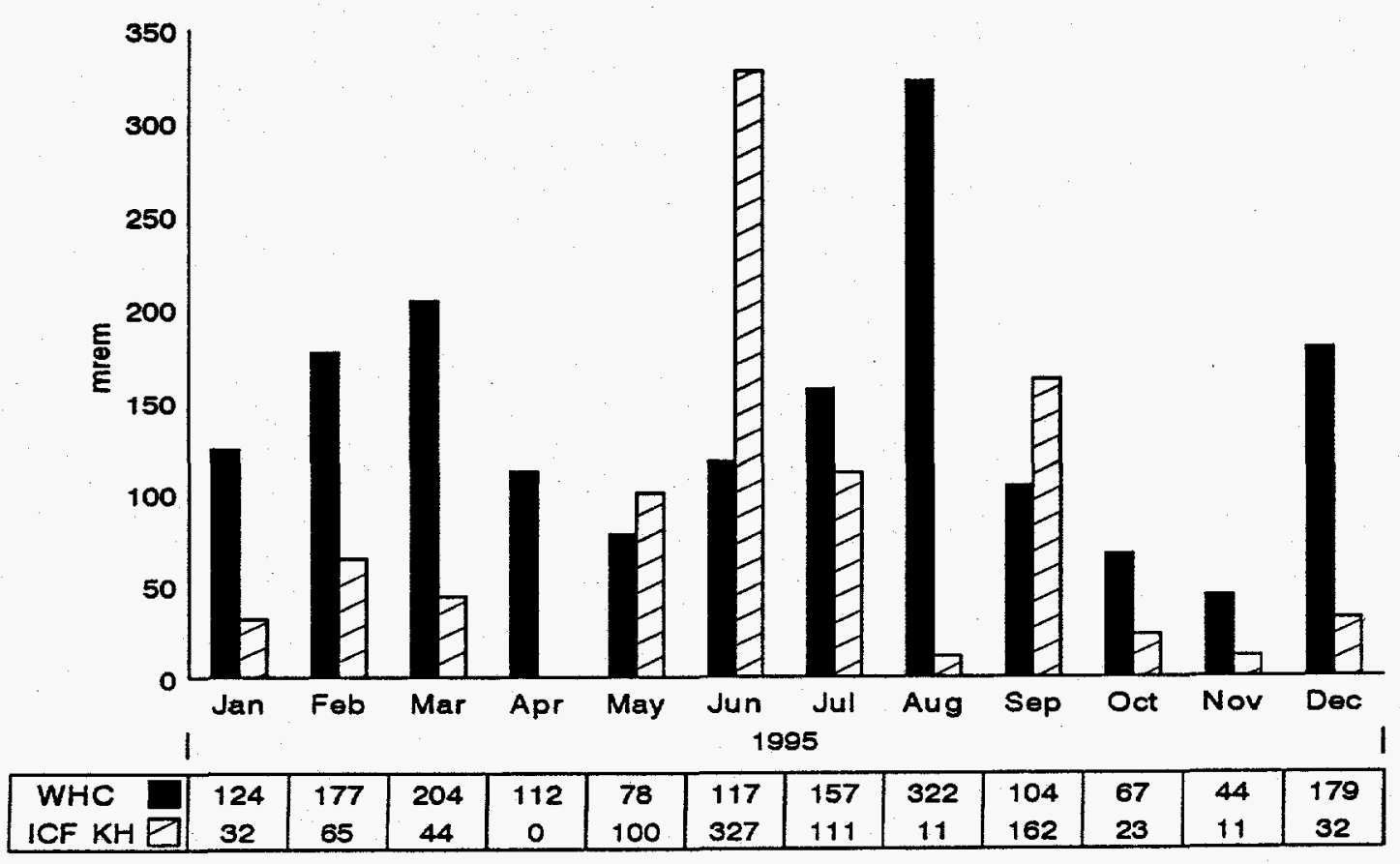




\subsection{INTERNAL DOSIMETRY}

Radiological Control is responsible for internal dosimetry emergency response following radiological events and for providing an internal dosimetry advisor to interface between: WHC, BCSR, and ICF KH workers, DOE, PNL Internal Dosimetry, WHC Dosimetry, HEHF, Radiological Control management and staff, and WHC Communications following events or positive routine bioassay examinations.

\subsubsection{Internal Depositions}

Beginning in CY 1993, the DOE Radiological Control Manual required the dose from internal depositions be calculated as the 50-year committed effective dose equivalent (CEDE), and DOE Order 5000.3B established reporting criteria for internal depositions as $\geq 100 \mathrm{mrem}$ CEDE.

\subsubsection{Internal Dose Incident Follow-Up}

There were two confirmed intakes of radioactive material with assessed CEDE greater than or equal to 100 mrem during the fourth quarter of CY 1995 by either wound or inhalation.

There were three instances of loss of contamination control during the calendar quarter involving eight workers where internal dosimetry follow-up was performed. Intakes greater than 100 mrem CEDE were detected for two of these employees. Intakes below $100 \mathrm{mrem}$ CEDE were assessed for four additional workers.

- On 10/23/95 there was a loss of contamination control while employees were working with bagged plutonium contaminated equipment at the $232-\mathrm{Z}$ incinerator facility. Follow-up bioassay was performed on five workers. All workers showed positive indications of plutonium uptakes. Two workers were assessed doses above $100 \mathrm{mrem} C E D E$, one at $210 \mathrm{mrem}$ and the other at $110 \mathrm{mrem}$ CEDE.

- On 11/8/95, follow-up bioassay was performed when air samples at the 102AY-2D sluice pit in the 200 East Tank Farms indicated workers may have exceeded the respiratory protection factor for their filtered respirators. Follow-up whole body counts showed no indications of an intake.

- On 11/9/95, a worker was contaminated on the face while drilling into concrete at the 100KE fuel storage basin. A follow-up bioassay and whole body count confirmed there was an intake of mixed fission products which contained trace amounts of transuranic contamination. The final assessed intake was 61 mrem CEDE from this intake.

\subsubsection{Direct (in vivo) and Indirect (in vitro) Measurement}

The statistics for total number of urine samples is based on the total number sampled. In vitro measurement statistics are presented in Figure 3-3-1 for CY 1995. Statistics are also included for invalid samples:

- No sample - Workers did not provide a sample for a delivered container

- Lost containers - Workers did not return the containers to the analytical laboratory, or as in the first quarter, the containers were deficient

- Insufficient volumes - Workers did not provide an acceptable amount of urine for analysis

- Lost in laboratory - The analytical laboratory lost the worker's sample during the processing. 
Figure 3-3-1. Indirect (In Vitro) Measurements

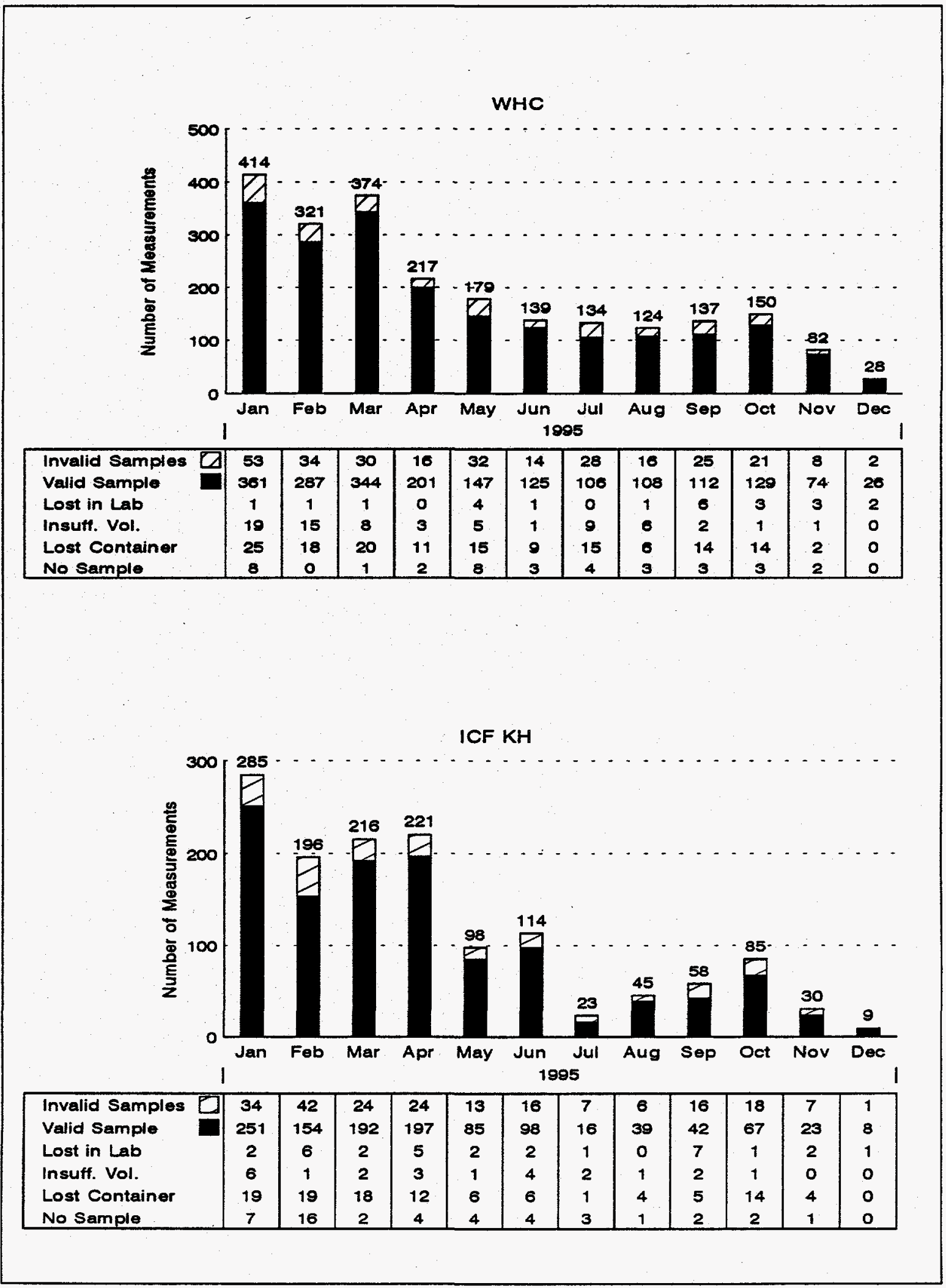


In vivo measurements are accumulated by measurement type: Whole body, chest (lung), and head. All other types of measurements performed (e.g., wound, thyroid) are contained in the "Other" category. The "no-show" category contains the number of chest measurements in which scheduled workers did not report to the PNL In Vivo Radioassay and Research Facility (Figure 3-3-2).

Figure 3-3-2. Direct (In Vivo) Measurements

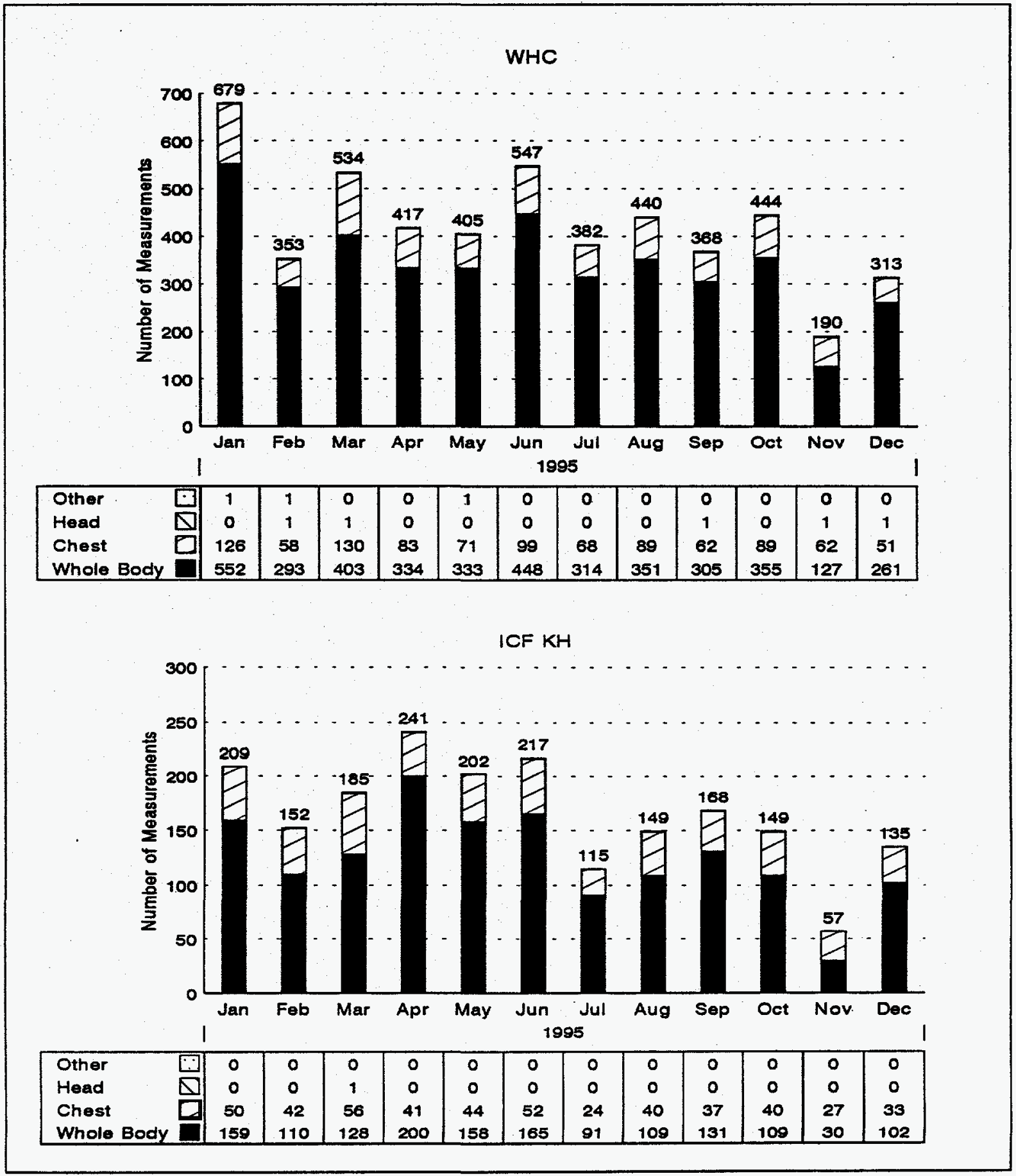




\subsection{SKIN AND CLOTHING CONTAMINATIONS}

Skin contaminations are of little consequence to employee health and safety, unless they result in significant radiation dose or internal depositions. Each skin contamination incident, however, does represent the potential for a more serious occurrence.

The numbers of all skin and clothing contaminations, with any detectable readings above background and excluding contaminations resulting from naturally occurring radon, are recorded here.

\subsubsection{Cumulative CY 1995 Skin Contaminations and Clothing Contaminations}

There were six skin contaminations and 24 clothing contaminations reported during the fourth calendar quarter in all WHC-managed facilities/areas. The totals for the year are: 29 skin and 79 clothing contaminations. Figure 3-4-1 charts cumulative data for the last three years.

The slight increase in the number of events in 1995 is more than offset by the increased amount of work in radiological zones during the year and indicates an overall improvement in the trend.

Figure 3-4-1. 1995 Skin and Clothing Contaminations Occurring in WHC-Managed Facilities/Areas

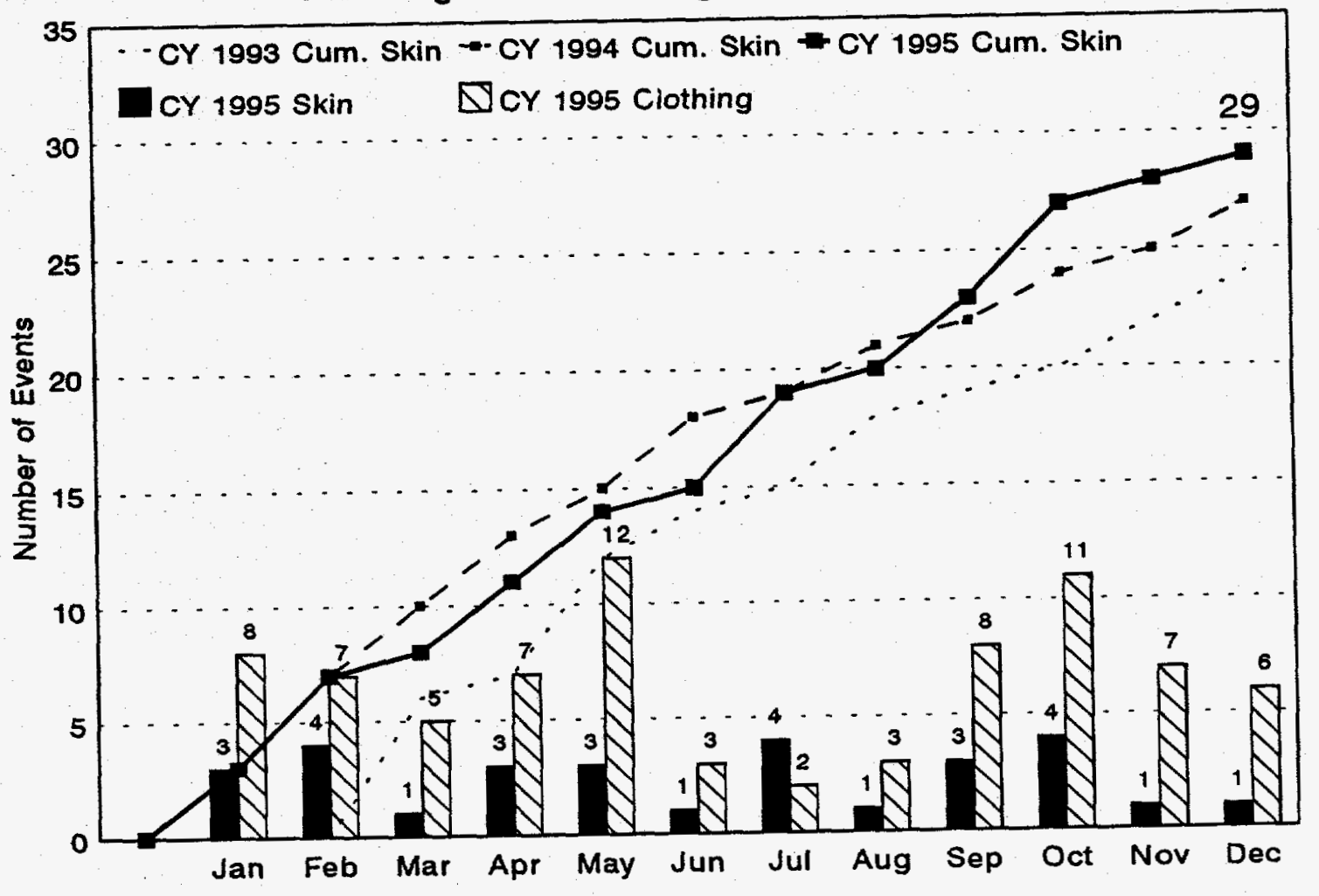




\subsubsection{Facility Comparisons for CY 1994 and CY 1995}

The increased work activities in Tank Farms, PFP, and Analytical Laboratory is reflected in the increased personal contaminations during the year. An excellent case management program at B Plant has resulted in the noteable improvement at that facility.

A two-year comparison of facility-specific skin and clothing contaminations can be made by referring to Figure 3-4-2.

Figure 3-4-2. Skin and Clothing Contamination Comparison by Facility

Skin Contaminations

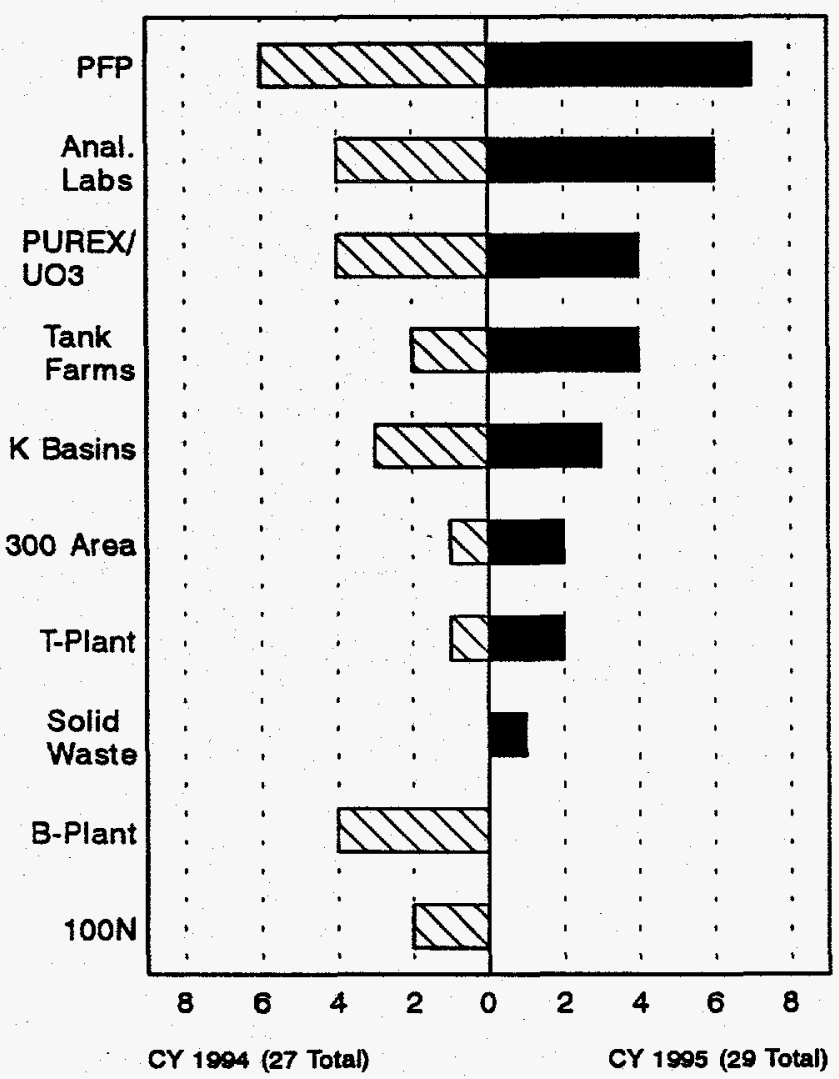

Clothing Contaminations

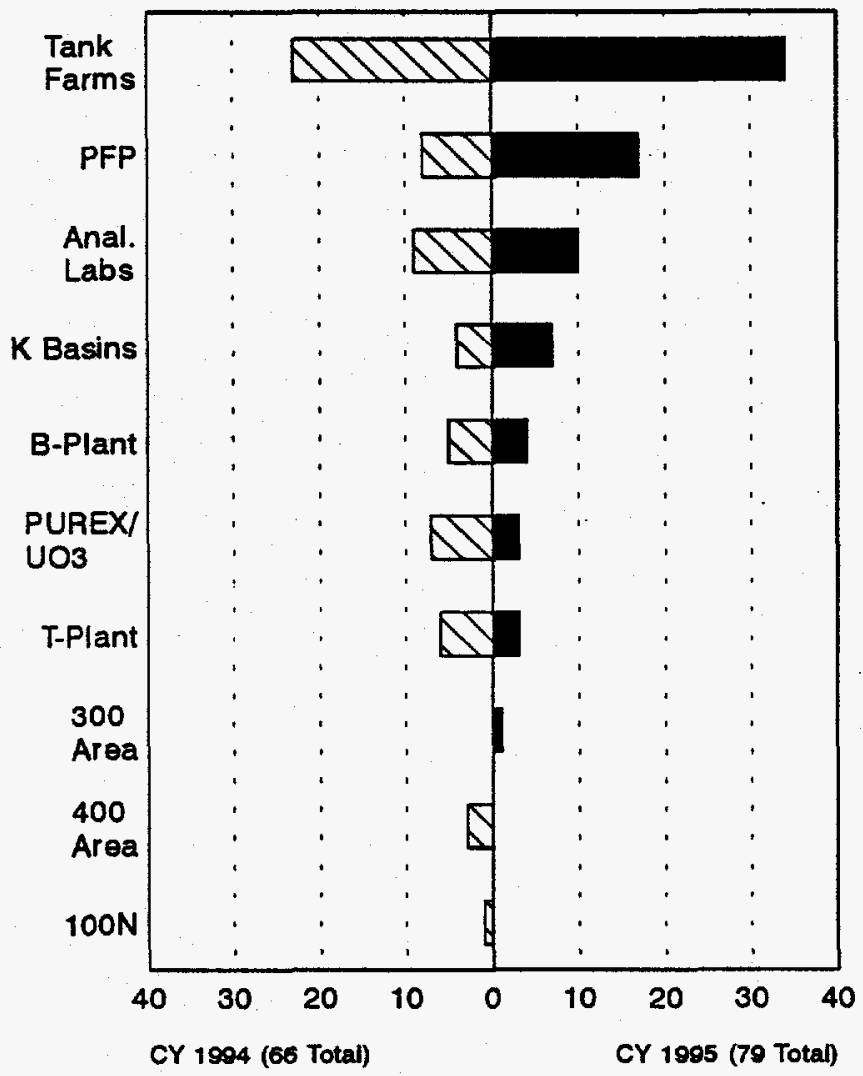

\subsubsection{Detection of Personal Contaminations}

The HPT continues to play a large role in detecting personal contaminations in the workplace. The method of first detecting the reported contaminations are as follows:

\begin{tabular}{ccccc}
$\begin{array}{c}\text { Type of } \\
\text { Contamination }\end{array}$ & $\begin{array}{c}\text { Health Physics } \\
\text { Technician }\end{array}$ & $\begin{array}{c}\text { Self } \\
\text { Survey }\end{array}$ & $\begin{array}{c}\text { Portal Contamination } \\
\text { Monitor }\end{array}$ & $\begin{array}{c}\text { Hand/Foot } \\
\text { Counter }\end{array}$ \\
\hline Skin & $15(52 \%)$ & $7(24 \%)$ & $7(24 \%)$ & 0 \\
Clothing & $35(44 \%)$ & $19(24 \%)$ & $24(31 \%)$ & $1(1 \%)$
\end{tabular}




\subsubsection{Significant Skin Contaminations.}

Significant skin contaminations are defined as a skin contamination resulting in a skin dose greater than or equal to one percent of the DOE dose limit, and are an indicator of the effectiveness of WHC radiation work practices and the efficiency of protective equipment. There have been no significant skin contaminations reported in WHC-managed facilities or areas since the one reported during CY 1988.

\subsubsection{Facial Contaminations}

Facial contaminations hold the potential for inhalation of radioactive material resulting in an internal deposition. The probable cause of the facial contamination incident occurring during this quarter is given below. Figure 3-4-3 depicts the number of facial contaminations for the last 12 months.

- On 10/23/95, two nuclear operators were detected to have positive nasal smears due to airborne contamination at $232-Z$ Building after handling waste. The highest smear read 109 dpm alpha.

- On 11/8/95, a pipefitter's mustache showed contamination following drilling work in the transfer area. Nasal smears were negative. Probable cause is listed as "job planning inadequate" pending further investigation.

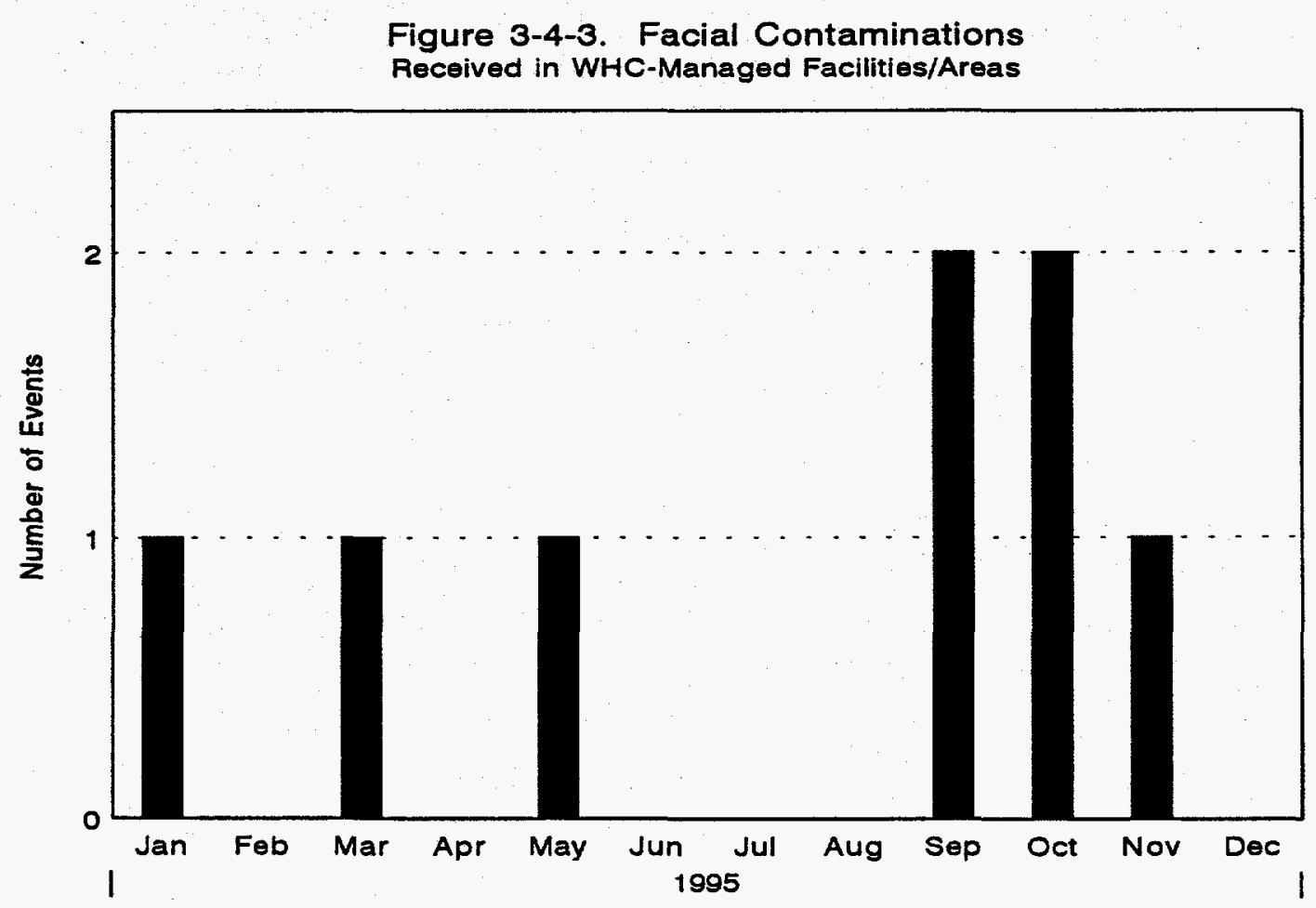




\subsubsection{Skin and Clothing Contamination Report Review}

The ALARA Program Office, along with Safety Awareness and Performance, and Dosimetry, performed analyses of the skin and clothing contaminations that occurred during CY 1995 in WHCmanaged facilities/areas. Skin and clothing contamination incident reports for all personal contaminations above background levels were reviewed for this analysis.

In most cases it appeared that a thorough and complete investigation has been completed and documented on the reports. However, review of the combined skin and clothing contamination reports indicated in over 33\% of the cases, the root cause was listed as "unknown." The analyses revealed, in many of these cases, that contributing factors had been considered but were unsubstantiated in determining the root cause for the "unknown" contaminations.

For purposes of this review, the root cause listed in the most current report was utilized. (Figure 3-4-4).

Figure 3-4-4. Personal Contaminations by Cause

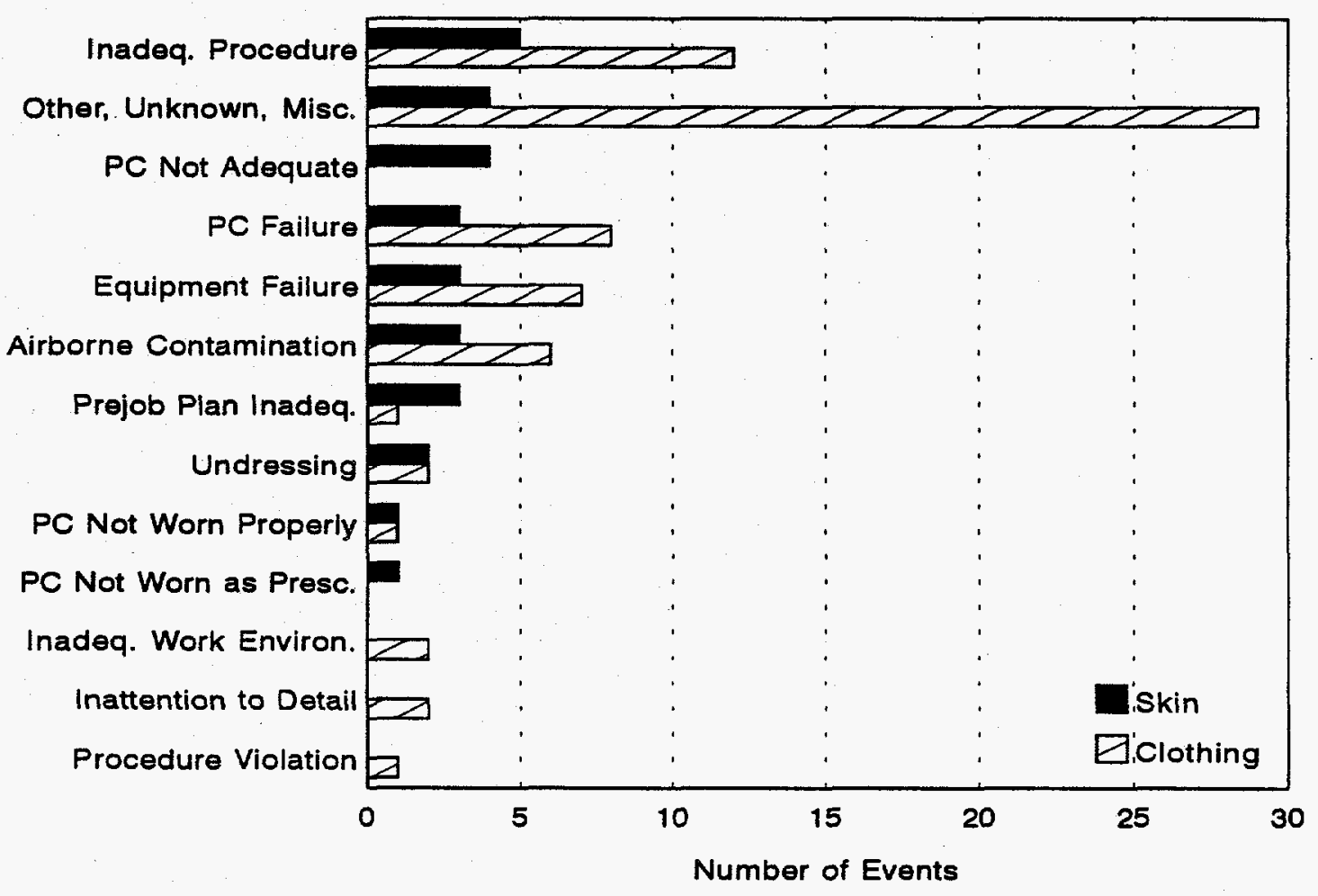




\subsubsection{Historical Skin Contaminations}

Figures 3-4-5 and 3-4-6 graph previous year data for comparison purposes. The yearly totals are for all detectable skin contaminations above background.

Figure 3-4-5. Twelve-Year Recordable Skin Contamination Comparison Period Ending 12/31/95

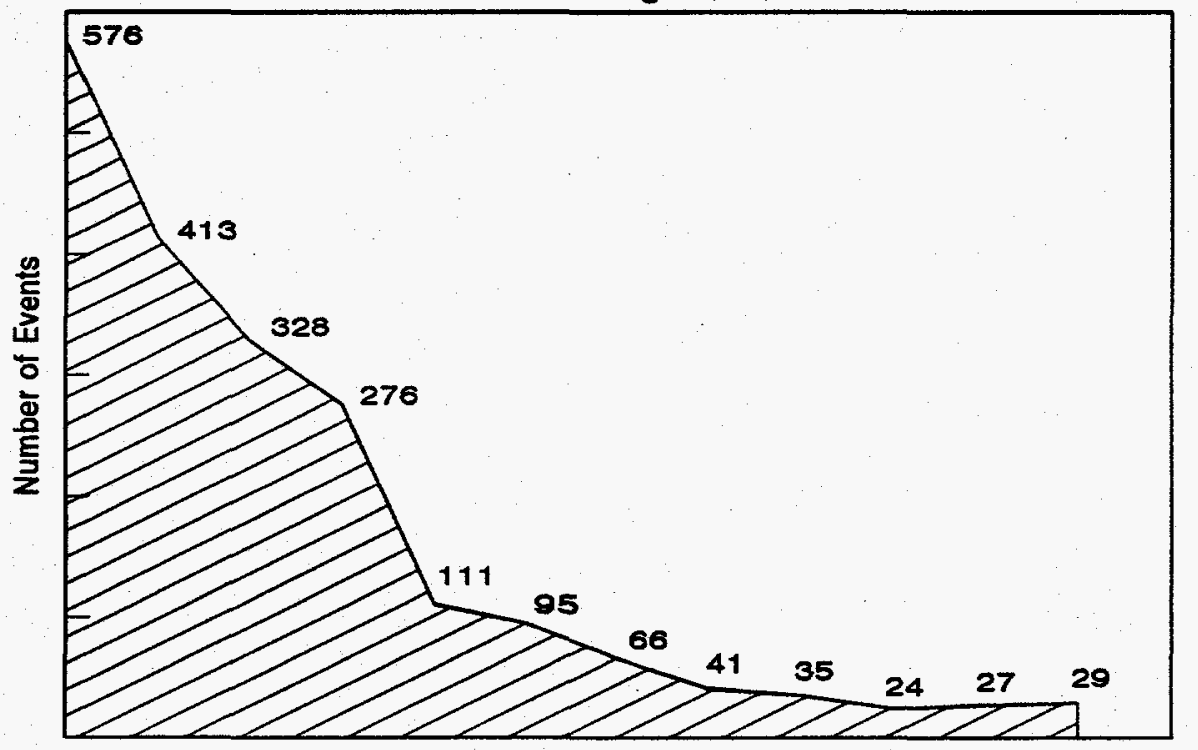

1984198519861987198819891990199119921993199419951996

Figure 3-4-6. Skin Contaminations Occurring in WHC-Managed Facilities/Areas

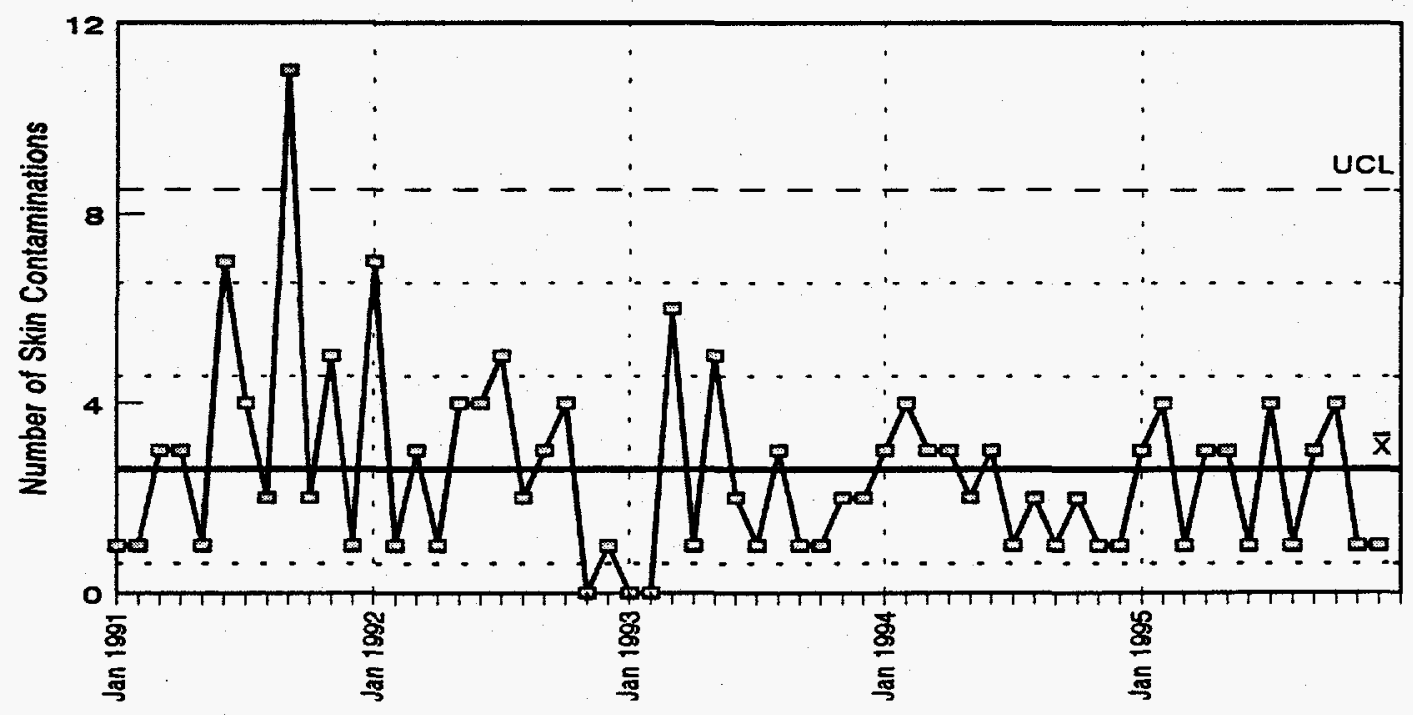




\subsection{RADIOLOGICAL PROBLEM REPORTS}

A Radiological Problem Report (RPR) is issued to responsible managers as a method to communicate problems needing correction, monitoring or tracking. Tracking the number of issued reports can provide an indication of both the number of problems needing attention and the adequacy of documentation of these problems by Radiological Control. Tracking the number of open reports provides an indication of the responsiveness of line management in resolving problems of a radiological nature.

A major enhancement to the radiological monitoring process was initiated during the fourth quarter of 1995 to provide a broader perspective to the activities of Radiological Control. Beginning on October 1, 1995, RPR-related reports from ORPS, and the skin and clothing reports from the Safety database have been included with the RPR database to provide a reporting system that encompasses all data related to radiological problems.

The deficiencies noted by the RPR system are coded by type and cause. This information allows for trending and analysis of data to provide management with:

- Knowledge and insights concerning the process operations affected,

- Types of deficiencies that are occurring,

- Causes of those deficiencies, and

- Ability to discern between common and special cause conditions in the effort to establish control limits and to better understand the patterns of process evolution and occurrence.

\subsubsection{RPRs Issued}

This report utilizes a comparison of the RPR reports of 1995 with the data from the previous yearly reports as a basis for relational measurement. A monthly average of 86 RPRs was issued during 1994 for a total issuance of 1035 RPR records. The monthly average for 1995 was 76 ; a total of 910 records (Figure 3-5-1).

Figure 3-5-1. Cumulative RPR Reports Issued

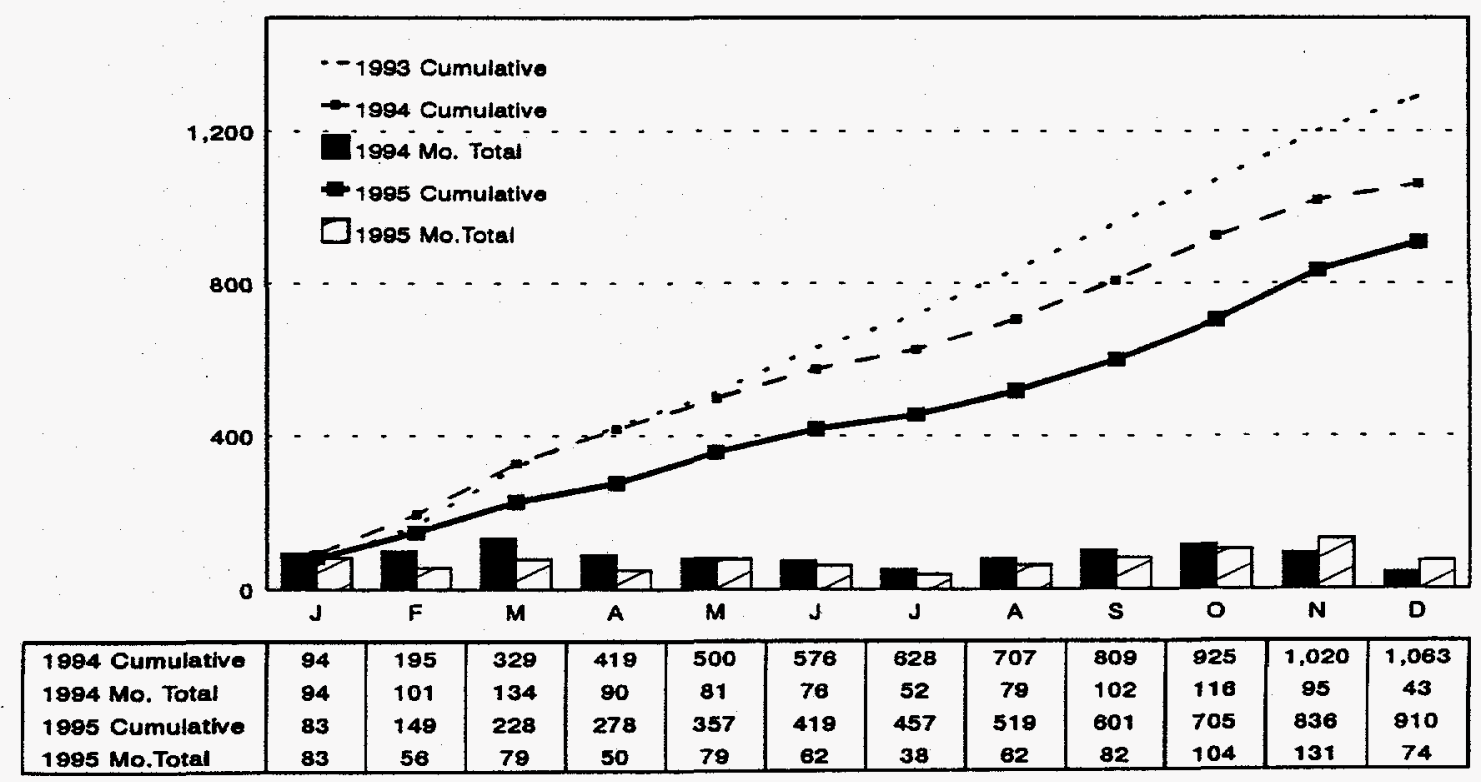


The total number of RPRs written during CY 1995,910 , was $12 \%$ fewer than the number written during 1994 and $14 \%$ fewer than the same reporting cycle for 1993 . An increasingly cooperative effort between Radiological Control and the responsible condition owners to avoid radiological problems through a proactive approach, ALARA, and the accountability activity and awareness more recently associated with the implementation of 10 CFR 835 , is attributable to this decreasing trend. Also, a more concerted effort has been placed upon the prescreening of initial RPRs by the issuing management teams in order to ensure the accuracy and validity of the RPR process.

\subsubsection{Factors Influencing the Number of RPRs Written}

- The general decrease in numbers of RPRs written from 1994 to 1995 reflect the continued downsizing of production at the Hanford facilities in addition to an increased awareness of radiological issues. Refer to Figure 3-5-2. For the purposes of this report, obsolete facilities have been dropped from the charts in Figure 3-5-2. Additionally, the facility activity for the Waste Sampling Characterization (WSCF), the Solid Waste Disposal Liquid Effluent Facility have been added as those facilities have gone into operation. The Core Sampling was separated from the TWRS East Tank Farm reports as a separate reporting facility for purposes of data tracking. In three individual settings, significant increases in PFP, B-Plant, and Process and Analytical Laboratories are attributable to the reporting system changes and the heightened awareness of the new rules and regulations for reporting radiological problems.

- Continued, increased awareness of ALARA principles and application to performance accounts for some of the decrease in reporting of deficiencies. Cooperative efforts between Radiological Control and its customers has brought more attention to ALARA as a continual approach to hazard management and safe job performance. The appearance of ALARA personnel in the work areas and the ALARA involvement with the planning of radiological work has also added value to radiological performance.

Figure 3-5-2. Facilities Issued RPRs, 1993-1995

WHC Facility Comparison With Past Years Of Performance

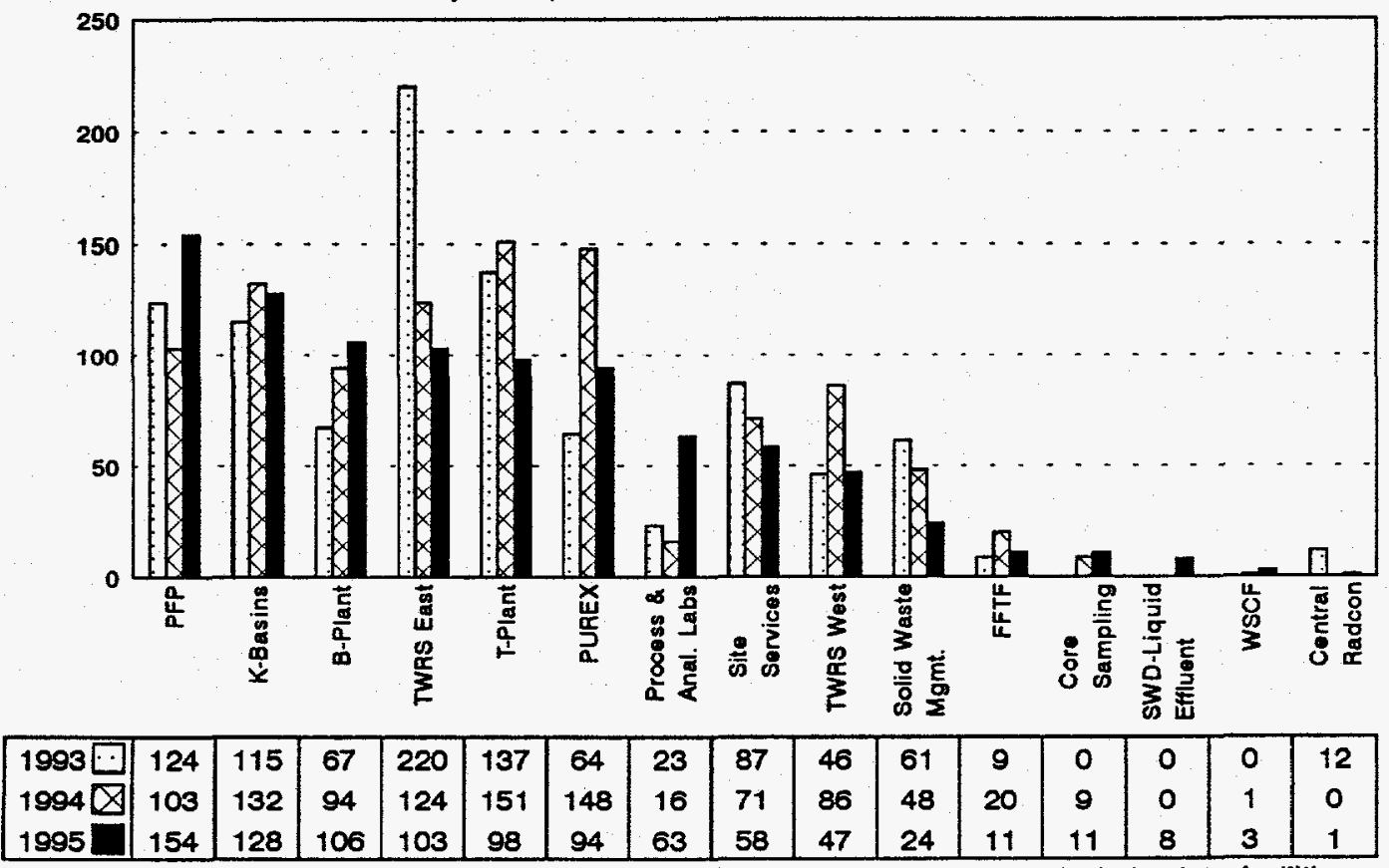

Note: Variences between previous and current year figures are due to removal of absolete facilities. 


\subsubsection{RPR Trends}

The deficiencies noted by the RPR system are coded by type, cause, and severity. This information allows extraction of the data for analysis of the types of deficiencies that are occurring, and the cause and severity of those deficiencies.

3.5.2.1 RPRs by Priority Planning Grid (PPG). When radiological deficiencies reach a significant level to require the development of corrective action, the Hanford Site uses the DOE-required PPG system to grade radiological and safety deficiencies.

The condition owner is responsible for determining the priority and weight of each deficiency requiring formal corrective action. Once this has been determined, assigned values make the evaluation of the urgency of completion more readily understandable and comparable with other corrective active measures. For further information, refer to WHC-CM-1-4, Corrective Action Management Manual, Sections 2.0 and 3.0.

During 1995, of all graded RPRs (233), about 48\% (112) have been weighted at under 6: "Routine response - no root cause analysis required, no lessons learned, no follow up." About nineteen percent (45) were weighted at $\geq 6$ and $<i 1$, and about $12 \%$ (27) were weighted at 11 . There were eight (about 3\%) graded above a PPG value of 12 .

Of the RPRs that have not been assigned PPG values, about 70\% (422 of 621) were issued for information only or were closed with rapid corrective actions within 30 days, as a continuing cooperative effort on the part of Radiological Control and its' customers, to maintain the site ALARA. Many of these RPRs, issued for information purposes, are record issues already being tracked by the facilities as occurrence reports, and these RPRs therefore were not evaluated for PPG since the primary tracking is done via the occurrence report system.

3.5.2.2 RPRs by Type and Cause. A total of 910 RPRs had been written on radiological deficiencies during 1995, and of those written, 601 were reported for various radiation contamination situations (EV-Event); which is $66 \%$ of the total written. Of all event-related RPRs issued (603), equipment/material contamination events were cited as the leading statistical attributes for this reporting cycle; about $64 \%$ (383). The next leading significant attribute was contamination control reports, which accounted for about $37 \%(222)$ of the statistical population for the EV-Event type.

Of all RPRs written, Personnel issues were identified as the primary direct cause (43\% or 393), with Material and Equipment (36\% or 327 ) as the second leading attribute. The reports for events with Unknown source or Legacy contamination, showed the greatest decrease between the 1994 and 1995 report cycle (an $80 \%$ drop in unknown conditions reported). This change is attributable to the reporting system changes and the heightened awareness of the new rules and regulations for reporting of radiological problems. Additionally, the ORPS October 30,1995, additions to the direct/root cause codes for legacy type and source unknown conditions (8A \& 8B) are expected to add better quantitative descriptors to these radiological attributes.

Of the RPRs listed with PPGs greater than or equal to 6 and less than 11, 57 (66\%) of them are type coded as Event. The leading cause in this area is listed as Equipment/material contamination (about $61 \%$ ) with personnel error related deficiencies listed as a cause for about $25 \%$ of the issues within this PPG range. 
The RPRs listed with a PPG of equal to or greater than 11 (35 each) list defective or failed equipment as the primary type (43\%) and Personnel error as the primary cause (40\%). The highest rated RPRs (PPG 22.0) dealt with the inadvertent drop of plywood into the K-basin water and an ion exchange module which failed to drain due to defective vent valves (RPRs: K-95-082 \& 083).

Radiological Problem Reports are written to document radiological noncompliances and/or inconsistencies with the HSRCM-1. The majority of them list radiological events (EV) as the primary types. Causal factors do need to be identified and investigated, especially those that recur. Personnel errors, administrative issues, procedural and training issues are observed and monitored, and the correlation of causal factors must be done at each field office, recurrences taken into account, and trends established. Taken together, equipment and personnel issues account for the majority of all coded RPRs for this report cycle. Radiological Control and the actionees have shown improvement in specifying causes and attempting to resolve them at low-level status. This effort is indicated by the significant decrease of the assignment of "other - unknown" as a cause (Figure 3-5-3).

Figure 3-5-3. RPRs by Type/Cause

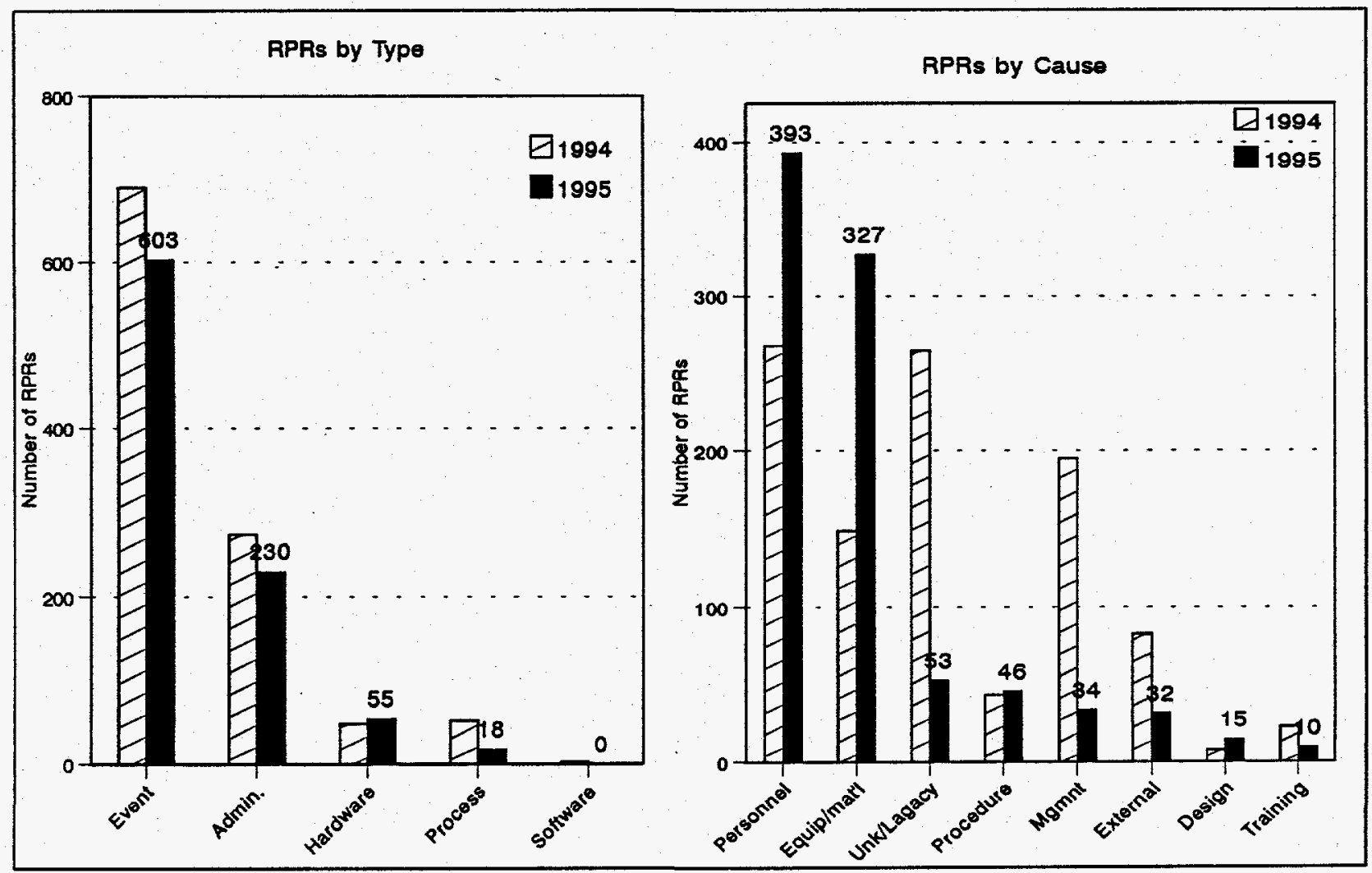

3.5.2.3 Contamination Events. The total number of contamination events reported for 1995 decreased from the previous 1994 report cycle by about 31\% (690 in 1994 to 603 in 1995). The primary causes listed for all radiological events include, Personnel Errors (about 43\%), and Equipment, Material and Hardware (about 36\%) as the leading issues. The Unknown source/Legacy contamination related causal category (about $6 \%$ ), accounted for the third leading variable. Management related and External attributes accounted for about $4 \%$ and $3.5 \%$ respectively. Design and training issues related to less then $2 \%$ of the total factors reported during 1995 (Figure 3-5-3). 


\subsection{DOSIMETRY}

The WHC Dosimetry organization administers the dosimetry system that measures and records various types of external and internal radiation exposures occurring in WHC-managed facilities. All record and supplemental dosimeters for WHC, BCSR, ICF KH, and DOE, all of their visitors, subcontractors, vendors and tour participants are issued and processed by the Dosimetry Group. These dosimeter data are recorded and reported as required.

The Dosimetry organization is responsible for tracking and monitoring declared pregnant workers, conducting monthly dosimeter audits and status reports, and in vivo and in vitro scheduling and reporting. To ensure exposures are kept ALARA, Dosimetry performs daily exposure checks and audits, provides the ALARA Program Office with daily input on exposures, and provides an ongoing history for tracking employees from date of hire to date of termination. All deadlines were met for the December 1995, year-end dosimeter exchange despite reduced staffing and the reengineering of Radiological Control.

At the end of December, Dosimetry was monitoring 11 pregnant workers on a monthly exchange. One dose of 11 mrem was recorded in October.

Work restrictions were issued for nonreturn of 498 dosimeters and 37 finger rings. These restrictions are placed directly on ACES and letters are mailed to the employee, and their manager, informing them of the restriction. The work restriction is lifted when the dosimeter, ring, or a dose estimate is received by Dosimetry. The increase in the number of restrictions placed is due to the year-end exchange.

Estimates and investigations of dosimeter results are performed when Dosimetry is notified of a lost or damaged dosimeter. The results of these investigations are sent to PNL to be included in the employee's record radiation exposure file. The increase in December is due to closing of year-end records.

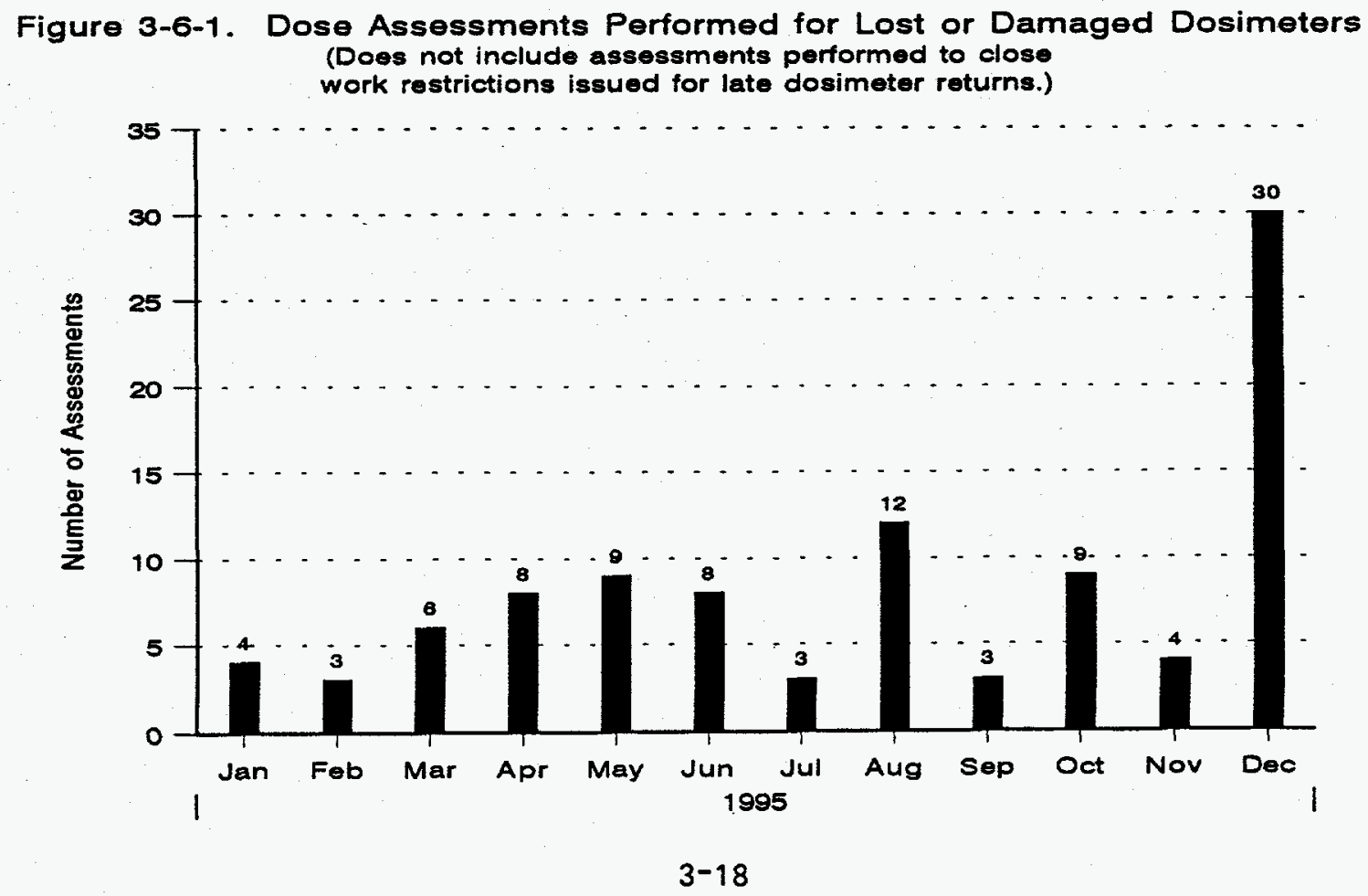




\section{REFERENCES}

BLS, Standard Industrial Classification Code Manual, SIC Code 4953, Bureau of Labor Statistics.

DOE, December 1994, Occupational Radiation Prctection, Title 10, Code of Federal Regulations, Part 835 (10 CFR 835), U. S. Department of Energy.

DOL, September 1986, Recordkeeping Guidelines for Occupational Injuries and Illnesses, O.M.B. No. 1220-0029, U. S. Department of Labor, Bureau of Labor Statistics, The Occupational Safety and Health Act of 1970 and CFR 1904.

PNL/WHC/HEHF/BHI, 1994, HSRCM-1, Hanford Site Radiological Control Manual, Rev. 2, Richland, Washington.

WHC, 1994, Corrective Action Management Manual, WHC-CM-1-4, Westinghouse Hanford Company, Richland, Washington.

WHC, 1995, Industrial Safety Manual, WHC-CM-4-3, Westinghouse Hanford Company, Richland, Washington.

WHC, 1995, Job Control System Manual, WHC-CM-8-8, Westinghouse Hanford Company, Richland, Washington.

WHC, 1995, Management Requirements and Procedures, WHC-CM-1-3, Westinghouse Hanford Company, Richland, Washington.

WHC, 1995, Occupational ALARA Program, WHC-IP-1043, Westinghouse Hanford Company, Richland, Washington

WHC, 1995, Radiation Protection Plan, WHC-SP-1145, Westinghouse Hanford Company, Richland, Washington

WHC, 1995, Safety Department Administrative Manual, WHC-IP-0030, Westinghouse Hanford Company, Richland, Washington

WHC/ICF KH, 1995, Industrial Hygiene Manual, WHC-CM-1-11, Westinghouse Hanford Company, Richland, Washington

WHC/ICF KH, 1995, Safety Manual, WHC-CM-1-10, Westinghouse Hanford Company, Richland, Washington 
This page intentionally left blank. 
WHC-SP-0564-40

\section{CONTENTS}

A-1 CY 1995 WHC ALARA Sitewide Goals $\ldots \ldots \ldots \ldots \ldots \ldots \ldots \ldots \ldots$

A-2 CY 1996 WHC ALARA Sitewide Goals $\ldots \ldots \ldots \ldots \ldots \ldots \ldots \ldots \ldots \ldots$

B-1 Injury/lliness Prevention Resources $\ldots \ldots \ldots \ldots \ldots \ldots \ldots \ldots \ldots \ldots$

B-2 WHC CY 1994 Recordable Vehicle Accidents - Second Quarter . . . . . . . . B-5

C-1 Skin and Clothing Contaminations Occurring in WHC-Managed Facilities $\ldots \ldots \quad C-1$

Glossary Abbreviations, Acronyms, and Initialisms . . . . . . . . . . GL-1

Definitions of Terms $\ldots \ldots \ldots \ldots \ldots \ldots \ldots \ldots \ldots \ldots$ GL-3

Distribution $\ldots \ldots \ldots \ldots \ldots \ldots \ldots \ldots \ldots \ldots \ldots \ldots \ldots \ldots \ldots \ldots \ldots \ldots \ldots$ 
WHC-SP-0564-40

This page intentionally left blank. 
Appendix A-1. CY 1995 WHC ALARA Site-wide Goals

\begin{tabular}{|c|c|c|}
\hline No. & Goal & ECD \\
\hline 1. & $\begin{array}{l}\text { Administer a written system to alert line management of individuals approaching } \\
\text { exposure administrative control guidelines. Data output reports will be } \\
\text { disseminated so' that adverse radiological trends can be readily identified and } \\
\text { corrected, as necessary. } \\
\text { Champion: ALARA/CCIP Program Office/ALARA Committees } \\
\text { Analysis of Performance: A review of the current ATAMS, identified in Section } \\
1.5, \text { was completed with a focus on improving and streamlining the process. } \\
\text { Changes were made to ensure that the facility ALARA Committee Chairpersons } \\
\text { were provided the opportunity to evaluate the exposure anomalies requiring } \\
\text { investigation. }\end{array}$ & $\begin{array}{l}09 / 30 / 95 \\
\text { Complete }\end{array}$ \\
\hline 2. & $\begin{array}{l}\text { Develop a system by which materials for employee training and retraining } \\
\text { incorporate lessons learned from the corrective actions listed in the radiological } \\
\text { occurrence reports and Post ALARA Reviews. } \\
\text { Champion: ALARA/CCIP Program Office/ALARA Council } \\
\text { Analysis of Performance: Don Gardner was assigned as a training liaison between } \\
\text { Radiological Control and the Training organizations. Due to reorganization efforts } \\
\text { Gardner is no longer working in that capacity. As needed, technical reviews of } \\
\text { ALARA/CCIP related training materials, by the WHC ALARA/CCIP Program Office, } \\
\text { assist in ensuring that lessons learned and corrective actions are incorporated into } \\
\text { employee training and retraining. Lessons learned and corrective actions are } \\
\text { provided to instructors for incorporation into appropriate courses and training. }\end{array}$ & \\
\hline 3. & $\begin{array}{l}\text { Develop and implement an employee "ALARA recognition program" to reward } \\
\text { workers that demonstrate an increased consciousness toward reducing their } \\
\text { exposure and the spread of radioactive contamination. } \\
\text { Champion: ALARA/CCIP Program Office/ALARA Council } \\
\text { Analysis of Performance: A new purpose statement which includes recognizing } \\
\text { and rewarding employees and teams that meet or exceed the established safety } \\
\text { performance criteria has been completed for the WHC ALARA Recognition } \\
\text { Program. Due to budgetary constraints the "ALARA Recognition Program" was } \\
\text { not budgeted during FY 1995. A limited number of ALARA awards remain in } \\
\text { stock to support this recognition program. }\end{array}$ & \\
\hline 4. & $\begin{array}{l}\text { Further integrate ALARA Program/Radiological Engineering support and } \\
\text { methodology within facilities by continuing to provide information at both the } \\
\text { operational and field levels. } \\
\text { Champion: ALARA/CCIP Program Office/Radiological Engineering } \\
\text { Analysis of Performance: The ALARA/CCIP Program Office Senior Health Physics } \\
\text { Analyst has been actively involved in increasing the field application of ALARA. } \\
\text { As a result of this, the field implementation and operational successes of ALARA } \\
\text { are on the increase as well as the use of radiological engineered devices. }\end{array}$ & $\begin{array}{l}09 / 30 / 95 \\
\text { Complete }\end{array}$ \\
\hline
\end{tabular}


WHC-SP-0564-40

\begin{tabular}{|c|c|c|}
\hline \multicolumn{3}{|c|}{ Appendix A-1. CY 1995 WHC ALARA Site-wide Goals } \\
\hline No. & Goal & ECD \\
\hline 5. & $\begin{array}{l}\text { Each ALARA Committee shall identify or develop a system to review, evaluate, } \\
\text { and implement applicable ALARA suggestions. } \\
\text { Champion: ALARA/CCIP Program Office/ALARA Committees } \\
\text { Analysis of Performance: All of the ALARA Committees have identified a method } \\
\text { to review, evaluate, and implement ALARA suggestions, as applicable. In an } \\
\text { effort to maximize the benefit while minimizing the costs, many of the ALARA } \\
\text { Committees will utilize preexisting Suggestion and Concerns programs. }\end{array}$ & $\begin{array}{l}09 / 30 / 95 \\
\text { Complete }\end{array}$ \\
\hline 6. & $\begin{array}{l}\text { Coordinate and sponsor an ALARA Workshop during FY } 1995 . \\
\text { Champion: ALARA/CCIP Program Office/ALARA Council } \\
\text { Analysis of Performance: Due to budgetary constraints, the ALARA Workshop } \\
\text { was not held as an exclusive training session. In conversations with RL, it was } \\
\text { determined that the ALARA/CCIP Program Office's participation in the Hanford } \\
\text { Health and Safety EXPO would exceed the intent of this goal. WHC ALARA/CCIP } \\
\text { Program was a major participant at the Hanford Health and Safety EXPO held in } \\
\text { April } 1995 \text {. With over } 5500 \text { Hanford employees in attendance, the EXPO } \\
\text { afforded a better opportunity to share the philosophies and advantages of ALARA } \\
\text { with a wide scope of employees and families. }\end{array}$ & $\begin{array}{l}\text { 09/30/95 } \\
\text { Complete }\end{array}$ \\
\hline 7. & $\begin{array}{l}\text { The WHC ALARA Program will be reviewed to ensure compliance with } 10 \text { CFR } \\
\text { 835, "Occupational ALARA Program" expectations. This shall include a review of } \\
\text { the site programs technical content and applicability. } \\
\text { Champion: ALARA/CCIP Program Office } \\
\text { Analysis of Performance: Two independent } 10 \text { CFR } 835 \text { reviews of the WHC } \\
\text { ALARA Program were conducted, including reviewing the programs controlling } \\
\text { document WHC-IP-1043. These reviews were conducted to ensure compliance } \\
\text { with } 10 \text { CFR } 835, \text { "Occupational ALARA Program." Dade Moeller \& Associates, } \\
\text { Inc., and Dr. Melvin Carter conducted the independent reviews of the WHC } \\
\text { ALARA Program. }\end{array}$ & $\begin{array}{l}\text { 09/30/95 } \\
\text { Complete }\end{array}$ \\
\hline 8. & $\begin{array}{l}\text { Develop a training package that covers the changes in the WHC ALARA Program } \\
\text { resulting from the changes in the WHC ALARA Program Manual. } \\
\text { Champion: ALARA/CCIP Program Office } \\
\text { Analysis of Performance: Training has been prepared and administered by the } \\
\text { ALARA/CCIP Program Office to include modifications due to the approval and } \\
\text { publication of WHC-IP-1043. Additionally, ALARA training courses have been } \\
\text { prepared explaining the purposes of and methods for completion of ALARA } \\
\text { documentation. These training course will continue to be provided throughout CY } \\
\text { 1996. }\end{array}$ & $\begin{array}{l}\text { 09/30/95 } \\
\text { Complete }\end{array}$ \\
\hline
\end{tabular}




\begin{tabular}{|c|c|c|}
\hline \multicolumn{3}{|c|}{ Appendix A-1. CY 1995 WHC ALARA Site-wide Goals } \\
\hline No. & Goal & ECD \\
\hline 9. & $\begin{array}{l}\text { Evaluate the necessity of developing a charter for the Hanford ALARA Forum. } \\
\text { Champion: ALARA/CCIP Program Office } \\
\text { Analysis of Performance: The evaluation indicated that this Forum, though very } \\
\text { valuable, could be combined with another group and accomplish the same } \\
\text { mission. All members of the Hanford Forum have been invited to join the WHC } \\
\text { ALARA Council. Representatives from ICF KH and PNL are actively attending the } \\
\text { Council. Representatives from Bechtel, HEHF, and WPPSS have been invited to } \\
\text { participate. }\end{array}$ & $\begin{array}{l}03 / 31 / 95 \\
\text { Complete }\end{array}$ \\
\hline 10. & $\begin{array}{l}\text { Develop and/or revise the facility/organizational specific ALARA implementing } \\
\text { procedure or plan (per the requirements of WHC-IP-1043) for each WHC ALARA } \\
\text { Committee. } \\
\text { Champion: ALARA/CCIP Program Office/ALARA Committees } \\
\text { Analysis of Performance: Dependent on the facilities current ALARA } \\
\text { implementation procedure or plan, facilities may not have to make changes in } \\
\text { order to comply with } 10 \text { CFR } 835 \text { requirements. Each facility is responsible for } \\
\text { reviewing and revising their ALARA implementing procedure, the WHC } \\
\text { ALARA/CCIP Program Office is available for assistance, as requested. }\end{array}$ & $\begin{array}{l}09 / 30 / 95 \\
\text { Complete }\end{array}$ \\
\hline 11. & $\begin{array}{l}\text { Maintain the number of skin contamination at } 0 \text { significant } 1<\text { or }=1 \% \text { of DOE } \\
\text { dose limit), and not more than } 29 \text { cumulative skin contamination events occurring } \\
\text { during CY } 1995 \text { at WHC-managed facilities/operations. } \\
\text { Champion: ALARA/CCIP Program Office/ALARA Committees } \\
\text { Analysis of Performance: Through CY 1995, there were } 27 \text { cumulative skin } \\
\text { contamination events. This goal was created and is reported using the "total } \\
\text { number" of detectable contamination events reported. It is important to note that } \\
\text { these numbers are created using different criteria than the Performance Based } \\
\text { Incentives for FY } 1995 \text {. }\end{array}$ & $\begin{array}{l}12 / 31 / 95 \\
\text { Complete }\end{array}$ \\
\hline 12. & $\begin{array}{l}\text { Maintain the CY } 1995 \text { annual cumulative radiological exposure for radiation } \\
\text { workers (monitored with a Hanford standard dosimeter) at WHC-managed } \\
\text { facilities/operations at less than } 185 \text { person-rem. } \\
\text { Champion: ALARA/CCIP Program Office/ALARA Committees } \\
\text { Analysis of Performance: A total of } 181 \text { person-rem was received by } \\
\text { WHC/BCSR/ICF KH employees during CY } 1995 \text {. This excludes internal } \\
\text { depositions of } 0.565 \text { person rem CEDE. This goal has been revised to include the } \\
\text { personnel exposure of ICF KH workers which was not included in the original } \\
\text { technical basis used to establish this goal. }\end{array}$ & $\begin{array}{l}12 / 31 / 95 \\
\text { Complete }\end{array}$ \\
\hline
\end{tabular}




\begin{tabular}{|c|c|c|}
\hline \multicolumn{3}{|c|}{ Appendix A-1. CY 1995 WHC ALARA Site-wide Goals } \\
\hline No. & Goal & $E C D$ \\
\hline 13. & $\begin{array}{l}\text { Maintain the number of personal effects clothing contamination events occurring } \\
\text { at WHC-managed facilities/operations for CY } 1995 \text { at } 73 \text { or less. } \\
\text { Champion: ALARA/CCIP Program Office/ALARA Committees } \\
\text { Analysis of Performance: Through CY } 1995 \text {, there were } 66 \text { cumulative clothing } \\
\text { contamination events. It should be noted that this number includes contamination } \\
\text { events that were in excess of the criteria established in DOE Order } 5000.3 B \text {, } \\
\text { "Occurrence Reporting and Processing of Operations Information," as well as } \\
\text { those that were detected below the reporting criteria. }\end{array}$ & $\begin{array}{l}12 / 31 / 95 \\
\text { Complete }\end{array}$ \\
\hline 14. & $\begin{array}{l}\text { Promote the reduction of radiological areas at WHC-managed facilities/operations } \\
\text { by a minimum of } 274,699.08 \text { square meters }(2,956,933 \text { square feet), in support } \\
\text { of the Contamination Control Improvement Project. } \\
\text { Champion: ALARA/CCIP Program Office/ALARA Committees } \\
\text { Analysis of Performance: During FY 1995, } 6,376,779 \text { square feet of radiological } \\
\text { area was reduced/downgraded. This goal was achieved early due in part to the } \\
\text { prioritization placed on this goal by the ALARA Committees. It is important to } \\
\text { note that the criteria for reporting this goal is different from the criteria used in } \\
\text { reporting the Performance Based Incentive (PBI) for FY } 1995 \text {. This goal was } \\
\text { established and calculated using all radiological area reductions versus only } \\
\text { contaminated area reductions being reported through the PBI. }\end{array}$ & $\begin{array}{l}09 / 30 / 95 \\
\text { Complete }\end{array}$ \\
\hline 15. & $\begin{array}{l}\text { Perform a quarterly review and evaluation of exposure tracking reports and } \\
\text { skin/personnel contamination incidents for potential trends during FY } 1995 \text {. If } \\
\text { trends are noted that are correctable, utilize the DORITE process to correct these } \\
\text { issues. } \\
\text { Champion: ALARA/CCIP Program Office/ALARA Council } \\
\text { Analvsis of Performance: A review and evaluation of the root causes of the } \\
\text { recorded skin/clothing contamination was completed. The available statistics have } \\
\text { not indicated any trends that the DORITE process can address. It is anticipated } \\
\text { that the reviews and evaluations of the contamination events will be continued by } \\
\text { the ALARA/CCIP Program Office throughout CY } 1996 \text {. }\end{array}$ & $\begin{array}{l}\text { 09/30/95 } \\
\text { Complete }\end{array}$ \\
\hline
\end{tabular}


WHC-SP-0564-40

\begin{tabular}{|c|c|c|}
\hline \multicolumn{3}{|c|}{ Appendix A-2. CY 1996 Site-wide ALARA Performance Goals } \\
\hline No. & Goal & ECD \\
\hline 1. & $\begin{array}{l}\text { Participate in and support the CY } 1996 \text { Health and Safety EXPO scheduled for } \\
\text { April } 10 \text { and } 11,1996 \text {. The WHC ALARA Council will assist in staffing an } \\
\text { ALARA Activities booth designed to increase Hanford employees awareness of } \\
\text { ALARA principles and practices. } \\
\text { Champion: ALARA Council }\end{array}$ & $06 / 30 / 96$ \\
\hline 2. & $\begin{array}{l}\text { The ALARA/CCIP Program Office will provide quarterly ALARA } \\
\text { training/demonstrations, utilizing the hands-on instruction approach, as applicable, } \\
\text { for ALARA Council and ALARA Committee members. This training will focus on } \\
\text { radiological and non-radiological ALARA issues in an effort to expand the } \\
\text { awareness of WHC employees to ALARA Principles. } \\
\text { Champion: WHC ALARA/CCIP Program Office }\end{array}$ & $12 / 31 / 96$ \\
\hline 3. & $\begin{array}{l}\text { Update and revise the WHC ALARA/CCIP Tools Listing to provide a source of } \\
\text { information that can be used to assist personnel in the planning, training and } \\
\text { execution of radiological work using the principles of ALARA. This revision will } \\
\text { include detailed information on the use and procurement of engineered controls, } \\
\text { conduct of pre-job briefings and post-job ALARA reviews. } \\
\text { Champion: WHC ALARA/CCIP Program Office }\end{array}$ & $06 / 30 / 96$ \\
\hline 4. & $\begin{array}{l}\text { Maintain the CY } 1996 \text { annual cumulative radiological exposure for radiation } \\
\text { workers (WHC and ICF KH monitored with a Hanford standard dosimeter) at } \\
\text { WHC-managed facilities/operations at less than } 300 \text { person-rem. } \\
\text { Champions: Facility ALARA Committees } \\
\text { - Note - This goal is a compilation of the facility specific ALARA goals, and will } \\
\text { be updated quarterly, as necessary, based on changes in the technical basis (i.e., } \\
\text { redefined work scope, clarification of ICF KH personnel exposure, etc.) used in } \\
\text { developing this goal. }\end{array}$ & $12 / 31 / 96$ \\
\hline 5. & $\begin{array}{l}\text { Promote the reduction/downgrading of radiological areas at WHC-managed } \\
\text { facilities/operations by a minimum of } 3.5 \text { million square feet, in support of the } \\
\text { Contamination Control Improvement Project. } \\
\text { Champions: Facility ALARA Committees }\end{array}$ & $12 / 31 / 96$ \\
\hline 6. & $\begin{array}{l}\text { Continue to demonstrate the reduction in the unnecessary use of respiratory } \\
\text { protection by documenting the amount of one time or routine activities where the } \\
\text { use of respirators was or would have been routinely employed in the past but, } \\
\text { due to application of the principles listed in HSRCM Article } 316 \text {, other engineering } \\
\text { controls were utilized to eliminate/reduce the use of respiratory protection for that } \\
\text { activity. } \\
\text { Champions: Facility ALARA Committees }\end{array}$ & $12 / 31 / 96$ \\
\hline 7. & $\begin{array}{l}\text { Track and trend unplanned exposures that exceed the Administrative Control } \\
\text { Levels as established in the Hanford Radiological Control Manual. Provide a } \\
\text { synopsis of the corrective actions assigned to prevent recurrence of similar } \\
\text { events. } \\
\text { Champion: WHC ALARA/CCIP Program Office }\end{array}$ & $12 / 31 / 96$ \\
\hline
\end{tabular}




\begin{tabular}{|c|l|c|}
\hline \multicolumn{1}{|c|}{ Appendix A-2. CY 1996 Site-wide ALARA Performance Goals } \\
\hline \hline No. & \multicolumn{1}{|c|}{ Goal } & ECD \\
\hline \hline 8. & $\begin{array}{l}\text { Maintain the number of skin and clothing contamination events at 0 significant } \\
\text { ( } \geq 1 \text { percent of DOE dose limit), and not more than } 69 \text { cumulative contamination } \\
\text { events occurring during CY } 1996 \text { at WHC-managed facilities or operations. } \\
\text { Champions: Facility ALARA Committees } \\
\text { - Note - This goal was created utilizing the information provided by the facility } \\
\text { specific ALARA goals and will be adjusted according to changes in workscope at } \\
\text { the facility level. }\end{array}$ & $12 / 31 / 96$ \\
\hline 9. & $\begin{array}{l}\text { Maintain new confirmed unplanned internal depositions that result in a committed } \\
\text { effective dose equivalent } \geq 100 \text { mrem at } \leq 2 \text { events during CY 1996. } \\
\text { Champions: Facility ALARA Committees }\end{array}$ & $12 / 31 / 96$ \\
\hline 10. & $\begin{array}{l}\text { Track and trend the instances of confirmed mission-related airborne radioactive } \\
\text { material concentrations greater than 10 percent of a DAC in occupied areas not } \\
\text { controlled and posted as Airborne Radioactivity Areas which result in personnel } \\
\text { being assigned a committed effective dose equivalent < } 100 \text { mrem. } \\
\text { Champion: WHC ALARA/CCIP Program Office }\end{array}$ & $12 / 31 / 96$ \\
\hline 11. & $\begin{array}{l}\text { Continue to decrease the number of uncontrolled/unwanted (i.e., non-legacy } \\
\text { contamination) releases of radioactive material, solid or liquid, into the work } \\
\text { environment reportable under DOE } 232.1 . \text { This goal will be accomplished if the } \\
\text { number of releases described above, in any six month award fee period, are less } \\
\text { than those that occurred during the last } 6 \text { months of FY 1995. } \\
\text { Champions: Facility ALARA Committees } \\
\text { Note - Legacy contamination is defined in DOE 232.1 as radiological or } \\
\text { hazardous material contamination attributed to past practices. }\end{array}$ & $12 / 31 / 96$ \\
\hline \hline
\end{tabular}




\title{
APPENDIX B-1
}

\author{
RESOURCES
}

Listed below are a variety of resources available to assist in the injury/illness prevention effort.

WHC Field Safety Offices - Staff members are available to assist the line manager and accident investigators with occupational injury/illness investigations. The staff members will also assist with hazard evaluations, review of work practices, and safety meetings. To request assistance, contact one of the following field safety points-of-contact.

- Transition Projects Safety - 372-0399

- Site Safety Programs - 372-2991

- Tank Waste Remediation Systems Safety - 373-6976

- Spent Nuclear Fuel Safety - 373-3464

- Safety Operations Support - 372-2598

WHC Industrial Safety and Fire Protection (IS\&FP) - This organization can provide the following:

- Occupational Injury/Illness Investigations - Accident Investigators are available to assist with investigation and OSHA recordability determination. To request assistance, contact 376-9146, $376-2354$, or 376-9003.

- Occupational Injury/IIness Information - To receive more information on the following, contact $376-8872,376-5325$, or $376-9141$.

- WHC/BCSR Occupational Injury/Illness Report - A report that is provided weekly on Soft Reporting which is sorted by organization code or facility.

- Daily Report of WHC/BCSR Occupational Injuries/Illnesses via cc:mail.

- President's Accident Prevention Committee (PAPC) - Information that is provided to the PAPC.

- Safety Meeting Materials - Many resources are available through the Safety Resource Center to assist individuals with conducting effective safety meetings. Resources available include videos, literature, safety meeting guest speakers, and assistance with individual safety programs. For information on these resources, contact the Safety Resource Center, 376-9059 or 376-8990.

- Safety Awareness Programs - For information regarding company wide health and safety awareness programs that have been implemented for prevention of occupational injuries, illnesses and accidents, contact $376-9059$ or $376-8990$.

ALARA - ALARA support is provided for goal development, training and awareness activities. For more information, contact 376-9035. 


\section{APPENDIX B-1 (Continued)}

Fall Protection Program Training - This training is mandated for employees who work at elevated work location where the potential injury due to falls is present. This training covers regulatory requirements, proper use, testing and maintenance of hardware and safety equipment. This training meets OSHA and WHC requirements for fall protection training certification of at-risk employees and their managers/supervisors. For additional information, call 376-0687 or 376-0913.

Behavioral-Based Safety Training Course is a behavior based approach to safety. The course allows participants to identify barriers to safety, discuss the three elements of a Total Safety Culture, and learn how they can implement seven fundamental principles of the safety process. The course is currently being offered once each month. This training supports, and is a critical implementation and operation factor for, the Voluntary Protection Program (VPP).

- Currently to schedule training, send your request by cc:mail to the Training Registration mailbox. In the cc:mail message, include employee name, payroll \#, charge code, name of class, and course code number 020107 . Also, if there is a date the employee is not available, include this information in order to avoid rescheduling of the class. Refer to Hanford Training Center (376-6736) if they have questions on how to use the cc:mailbox. Planned enhancements will allow direct scheduling of the employees via the HLAN and PeopleSoft.

Additional support training for implementation of behavioral-based safety processes is available to Accident Preventions Councils, Safety Teams, or Safety Work Groups. To schedule a class, contact Health and Safety Training (372-3910).

Confined Space Entry Program Training - This course covers all life critical concerns for employees required to enter or work in confined spaces. The training covers the regulatory requirements, and proper use and testing of the appropriate safety harness and equipment required for confined space entry. This training is required for all entrants, attendants, and oversight personnel that are involved with a confined space entry. For more information contact 372-3110 or 376-0913.

Safety Observer Training - This course is designed to assist in the training of employees in the recognition of the basic causes of accidents in the work place (unsafe acts and unsafe conditions). Program provides 8 to 10 hours of OSHA initial training, hazard recognition training, refresher Behavior Based Safety Training and various issue specific follow up training modules on request. For information, contact 372-3910, or 376-0913.

Occupational Safety and Health Program Training - This course is the four day presentation of the OSHA Code of Federal Regulations (CFR) 1910. The training provides an overview and understanding of the applicable Federal Regulations for the operations of the Hanford Site. The training instructs the student in the methods of using the CFR's as a resource, and recognition of hazards within the work place as identified by OSHA. For additional information call 376-0913.

Lock and Tag Program Training (initial and refresher) - This training is required for all employees that are classified as "authorized workers" within the site definition. This includes all employees that administer, verify, install or remove locks and tags in support of the established site procedure. The training addresses regulatory requirements, proper procedures and documentation requirements for the sitewide program. Additional information regarding the training and prerequisites can be obtained by calling $376-0830$ or $376-0913$. 
Managers Safety Training - The course is designed to provide an initial four hour block of classroom training, followed with several one or two hour modules to be completed through-out the year as part of the managers Safety Improvement Plan. This allows the individual manager to schedule the training modules as needed or as available for optimum flexibility. For additional information call 372-3200 or 376-0913.

Root Cause Analysis - Attendees of this course develop an understanding of several analysis methods for use in accident investigations. For information on this course, contact DOE-RL Quality Training and Resource Center (QTRC) on 376-7117.

Back Up - Back Health Series: - Four presentations are 60 minutes and are designed to improve. To schedule a particular presentation, managers may cc:mail *HEHF Worksite Health, or call $376-0655$.

- BackUp I - Back to Basics (Prerequisite class) - Participants are taught back health essentials.

- BackUp II - All the Right Moves - Safe lifting techniques and proper body mechanics are discussed.

- Back Up III - Adjusting Your Hardware, Maintaining Your Software - This ergonomics program includes practical information on workstation adjustments and exercises for comfort and health.

- BackUp IV - Backtivity - Prevent and/or reduce back pain with strengthening and stretching exercises.

Your Healthy Back - This is a four hour course that is offered by QTRC. This class also provides employees with information on what are the common reasons for back injury, and ways to prevent back injuries. A portion of this program is devoted to a stretching and strengthening session. For more information, contact 376-7117.

Supervising to Prevent Back Injuries - This is a five hour course that provides supervisors with information pertaining to the prevention of back injuries in the work place. For more information, contact QTRC (376-7117).

Wellness Seminars - Wellness seminars are available by HEHF Occupational Health professionals for delivery at the Hanford site on a request basis to groups of 12 or more employees. These presentations have been designed to promote employee health and safety, increase productivity and well-being, as well as reduce absenteeism.

Listed are the titles of the seminars offered by HEHF Worksite Health. To receive information or schedule a particular seminar, managers may cc:Mail HEHF Worksite Health mailbox, or call HEHF Worksite Health at 376-0655. Please schedule your presentations at least three weeks in advance. 


\section{APPENDIX B-1 (Continued)}

- Adapting to Stress video

- Battling Bug Bites (April - Sept.)

- Coping with Allergies video

- Don't Diet, Think Light video

- Heat Stress

- Humor Risk and Change video

- Laughter in the Workplace video
- Lighten up video

- No More Headaches video

- Self Care-Cold \& Flu

- Sleep-Good Morning Sleep Education

- Smoking Cessation (offered twice a year)

- Working Mom's Survival Guide video

Below you will find the titles of the seminars offered by HEHF Behavioral Health Services. To receive information or schedule a particular seminar, call 376-1282.

- Achieving a Balanced Lifestyle

- Anger Management

- Be Your Best You

- Coping with Change
- I Have This Friend

- Just Relax

- Saving for Stress

- Talking to Yourself Can Drive You Sane

Exercise/Fitness - Walklife - Become a member of the Hanford Site walking club. Membership includes a bimonthly newsletter and incentives. 


\begin{tabular}{|c|c|c|c|c|}
\hline \multicolumn{2}{|c|}{ CY 1995 Recordable Government Vehicle Accidents } \\
\hline Date & \$ Amount & Area & $\begin{array}{c}\text { Organization } \\
\text { Code }\end{array}$ & \multicolumn{1}{c|}{$\begin{array}{c}\text { Description of } \\
\text { Accident }\end{array}$} \\
\hline $01 / 05 / 95$ & $\$ 1,032$. & $\begin{array}{c}2722 \text { W 21st St, } \\
\text { 200W Area }\end{array}$ & 7CB53 & $\begin{array}{l}\text { Employee approached } \\
\text { government truck from } \\
\text { behind, entered the truck and } \\
\text { was backing when it struck } \\
\text { an unoccupied parked vehicle } \\
\text { with the tailgate lift. The } \\
\text { parked vehicle sustained } \\
\text { damage to the right front } \\
\text { door and right front window. } \\
\text { There were no injuries. }\end{array}$ \\
\hline $01 / 24 / 95$ & $\$ 7,420$. & $\begin{array}{l}\text { 3705 Bldg. } \\
\text { Parking Lot, } \\
\text { 300 Area }\end{array}$ & $2 C 110$ & $\begin{array}{l}\text { Employee was backing } \\
\text { government vehicle from } \\
\text { parking area to gain access } \\
\text { to street. The employee saw } \\
\text { an orange cone on top of a } \\
\text { concrete light pole base, } \\
\text { proceeded to back the } \\
\text { vehicle, misjudged the } \\
\text { location of the light base, } \\
\text { and struck the light base } \\
\text { puncturing the vehicle's gas } \\
\text { tank. There was } \\
\text { approximately 2 gallons of } \\
\text { unleaded gas spilled. } \\
\text { Vehicle damage - \$800. Gas } \\
\text { spill clean/disposal costs - } \\
\text { \$6,620. There were no } \\
\text { injuries. }\end{array}$ \\
\hline
\end{tabular}


WHC-SP-0564-39

Appendix B-2

CY 1995 Recordable Government Vehicle Accidents

\begin{tabular}{|c|c|c|c|c|}
\hline Date & \$ Amount & Area & $\begin{array}{l}\text { Organization } \\
\text { Code }\end{array}$ & $\begin{array}{l}\text { Description of } \\
\text { Accident }\end{array}$ \\
\hline 02/08/95 & $\begin{array}{c}\text { WHC vehicle - } \\
\$ 5,527 \text {. } \\
\text { (Other site } \\
\text { contractor } \\
\text { vehicle's } \\
\text { damage - } \\
\$ 6,665 \text { ) }\end{array}$ & $\begin{array}{l}\text { Rt 4S., MP 10.5, } \\
600 \text { Area }\end{array}$ & 33140 & $\begin{array}{l}\text { A WHC employee was } \\
\text { driving a government vehicle } \\
\text { slowly on the right shoulder } \\
\text { of the road while looking for } \\
\text { the turn to an unfamiliar } \\
\text { work location. Upon } \\
\text { spotting the turn on the } \\
\text { opposite side of the road, the } \\
\text { employee pulled the } \\
\text { government vehicle back } \\
\text { onto the roadway in } \\
\text { preparation to turn left. } \\
\text { Moments after signaling and } \\
\text { beginning the turn, another } \\
\text { contractor government } \\
\text { vehicle, which was } \\
\text { attempting to pass, collided } \\
\text { broadside causing extensive } \\
\text { damage to both vehicles, as } \\
\text { well as injury to the two } \\
\text { drivers and a passenger of } \\
\text { the second vehicle. }\end{array}$ \\
\hline 03/09/95 & $\$ 1,311$ & $\begin{array}{l}\text { Camden \& 23rd } \\
\text { St., 200W Area }\end{array}$ & 7C913 & $\begin{array}{l}\text { The employee was driving a } \\
\text { government vehicle North on } \\
\text { Camden, turning left onto } \\
\text { 23rd Street. As the vehicle } \\
\text { was rurning, a clipboard } \\
\text { placed on the dashboard of } \\
\text { the vehicle slid off } \\
\text { distracting the employee } \\
\text { momentarily. The employee } \\
\text { tried to reach for the } \\
\text { clipboard, overcorrecting the } \\
\text { vehicle. The driver's side } \\
\text { mirror struck a power pole } \\
\text { and the bottom side of the } \\
\text { vehicle struck a junction box } \\
\text { attached to the power pole. } \\
\text { There were no injuries. }\end{array}$ \\
\hline
\end{tabular}




\begin{tabular}{|c|c|c|c|c|}
\hline \multicolumn{5}{|c|}{$\begin{array}{c}\text { Appendix B-2 } \\
\text { CY } 1995 \text { Recordable Government Vehicle Accidents }\end{array}$} \\
\hline Date & \$ Amount & Area & $\begin{array}{l}\text { Organization } \\
\text { Code }\end{array}$ & $\begin{array}{l}\text { Description of } \\
\text { Accident }\end{array}$ \\
\hline 04/03/95 & $\$ 714$ & $\begin{array}{l}\text { North of MO240 } \\
\text { Parking Lot, } \\
\text { 200W Area }\end{array}$ & 018B0 & $\begin{array}{l}\text { The employee pulled into the } \\
\text { MO240 parking area to let a } \\
\text { passenger out of the vehicle. } \\
\text { While backing, the left rear } \\
\text { quarter panel, left back door, } \\
\text { and rear bumper were } \\
\text { damaged when the truck } \\
\text { struck a utility pole guy } \\
\text { wire. There were no } \\
\text { injuries. }\end{array}$ \\
\hline 05/01/95 & $\$ 660$ & $\begin{array}{c}\text { Heavy Equipment } \\
\text { Repair Shop } \\
1100 \text { Area } \\
\text { Door } 94\end{array}$ & $3 C 220$ & $\begin{array}{l}\text { While attempting to drive } 75 \\
\text { foot fire truck through the } \\
\text { bay door, the employee } \\
\text { misjudged the distance } \\
\text { required to maneuver and } \\
\text { struck a guard post, resulting } \\
\text { in two } 5 \text { ' scratches on the } \\
\text { right side of the truck. } \\
\text { There were no injuries. }\end{array}$ \\
\hline 05/09/95 & $\$ 853$ & $\begin{array}{l}\text { Camden Ave, } \\
200 \mathrm{ft} \text {. So. of } \\
19 \text { th St. } \\
200 \mathrm{~W} \text { Area }\end{array}$ & $3 B 550$ & $\begin{array}{l}\text { Driver was attempting to } \\
\text { make a right turn, cut too } \\
\text { close and struck power pole } \\
\text { with drivers side mirror, } \\
\text { pushing the mirror into } \\
\text { driver's window and } \\
\text { damaging driver's side door. } \\
\text { There were no injuries. }\end{array}$ \\
\hline $05 / 27 / 95$ & $\$ 1,312$ & $\begin{array}{c}\text { 119KE Parking } \\
\text { Area } \\
\text { 100K Area }\end{array}$ & $2 A 400$ & $\begin{array}{l}\text { Driver found vehicle parked } \\
\text { in "No Parking" area. } \\
\text { Performed } 360 \text { degree } \\
\text { walkaround, noticing it was } \\
\text { close to some poles on the } \\
\text { left side. While backing at } \\
1-2 \text { mph, sideswiped the last } \\
\text { pole causing damage to the } \\
\text { left rear fender area. There } \\
\text { were no injuries. }\end{array}$ \\
\hline
\end{tabular}


WHC-SP-0564-39

\begin{tabular}{|c|c|c|c|c|}
\hline \multicolumn{5}{|c|}{$\begin{array}{c}\text { Appendix B-2 } \\
\text { CY } 1995 \text { Recordable Government Vehicle Accidents }\end{array}$} \\
\hline Date & \$ Amount & Area & $\begin{array}{l}\text { Organization } \\
\text { Code }\end{array}$ & $\begin{array}{l}\text { Description of } \\
\text { Accident }\end{array}$ \\
\hline $06 / 12 / 95$ & $\$ 1,737$ & $\begin{array}{l}\text { Highways } 240 \text { and } \\
24 \text {, Northwest } \\
\text { Corner }\end{array}$ & $3 C 300$ & $\begin{array}{l}\text { Driver was on a burn detail } \\
\text { to burn tumbleweeds from } \\
\text { fencelines. The fire was } \\
\text { burning along the fence and } \\
\text { started to approach a light } \\
\text { pole. While attempting to } \\
\text { reposition the vehicle to } \\
\text { protect the pole, the driver } \\
\text { backed into another pole. } \\
\text { There were no injuries. }\end{array}$ \\
\hline $06 / 22 / 95$ & $\$ 25,000$ & $\begin{array}{l}222 S \\
200 W \text { Area }\end{array}$ & 43150 & $\begin{array}{l}\text { After employee completed } \\
\text { delivery, entered the } \\
\text { government truck, and } \\
\text { backed into the laboratory's } \\
\text { diesel exhaust fan duct } \\
\text { support structure. There } \\
\text { was no damage to the truck } \\
\text { and there were no injuries. }\end{array}$ \\
\hline 07/24/95 & $\$ 604$ & $\begin{array}{l}2355 \text { Stevens Dr. } \\
\text { West Dock } \\
\text { Richland }\end{array}$ & 43150 & $\begin{array}{l}\text { A truck driver was pulling } \\
\text { along side of the loading } \\
\text { dock and the extended fender } \\
\text { caught on the dock board } \\
\text { causing damage to the left } \\
\text { front fender extension. } \\
\text { There were no injuries. }\end{array}$ \\
\hline $07 / 25 / 95$ & $\$ 2,123$ & $\begin{array}{l}\text { ROB Bldg. } \\
\text { Battelle Blvd. } \\
\text { Richland }\end{array}$ & $4 \mathrm{C} 200$ & $\begin{array}{l}\text { Employee was turning left } \\
\text { into the parking lot at the } \\
\text { ROB Bldg and was struck by } \\
\text { a bicyclist. The bicyclist } \\
\text { received minor injuries. The } \\
\text { bicycle was damaged beyond } \\
\text { repair and the sedan received } \\
\text { damage to the windshield, } \\
\text { right front } 1 / 4 \text { panel, hubcap } \\
\text { and right front tire. }\end{array}$ \\
\hline 08/05/95 & $\$ 3,704$ & $\begin{array}{c}\text { NW Corner of } \\
\text { Wisconsin and } \\
\text { Spruce } \\
300 \text { Area }\end{array}$ & $3 \mathrm{C} 210$ & $\begin{array}{l}\text { Employee was making left } \\
\text { turn into gravel parking lot } \\
\text { at the } 329 \text { Bldg. and hit a } \\
\text { telephone pole with the left } \\
\text { front of the truck. The } \\
\text { driver was not injured. }\end{array}$ \\
\hline
\end{tabular}




\begin{tabular}{|c|c|c|c|c|}
\hline \multicolumn{5}{|c|}{$\begin{array}{c}\text { Appendix B-2 } \\
\text { CY } 1995 \text { Recordable Government Vehicle Accidents }\end{array}$} \\
\hline Date & $\$$ Amount & Area & $\begin{array}{l}\text { Organization } \\
\text { Code }\end{array}$ & $\begin{array}{l}\text { Description of } \\
\text { Accident }\end{array}$ \\
\hline $08 / 28 / 95$ & $\$ 1,384$ & $\begin{array}{l}\text { Well \#199-N-62 } \\
100 \text { N Area }\end{array}$ & 0M624 & $\begin{array}{l}\text { Employee was driving along } \\
\text { a fence line looking for a } \\
\text { well. He backed up on a } \\
\text { dirt road for approx. } 150 \text { yds } \\
\text { and backed into a protective } \\
\text { post. The driver was not } \\
\text { injured. }\end{array}$ \\
\hline $09 / 21 / 95$ & $\$ 975$ & $\begin{array}{c}\text { 609-C } \\
\text { Central Fire } \\
\text { Station }\end{array}$ & 36000 & $\begin{array}{l}\text { An employee driving his } \\
\text { personal vehicle backed into } \\
\text { a government mail van that } \\
\text { was not properly parked. } \\
\text { The private vehicle was not } \\
\text { damaged and there were no } \\
\text { injuries. }\end{array}$ \\
\hline $10 / 04 / 95$ & $\$ 596$ & $\begin{array}{c}328 \text { Bldg. Parking } \\
\text { Lot } \\
300 \text { Area }\end{array}$ & $8 A 400$ & $\begin{array}{l}\text { Driver was attempting to } \\
\text { back into a parking spot and } \\
\text { hit an } 18^{\prime \prime} \text { stack of steel } \\
\text { damaging the right front } \\
\text { door of the pickup. There } \\
\text { were no injuries. }\end{array}$ \\
\hline $12 / 11 / 95$ & $\$ 10,002$ & $\begin{array}{l}\text { Route 11A, } \\
\text { Milepost 11.5 } \\
\text { Hanford Site }\end{array}$ & $8 \mathrm{P} 550$ & $\begin{array}{l}\text { Driver was approaching } \\
\text { intersection traveling } 30-35 \\
\text { mph. The road was icy and } \\
\text { the vehicle failed to stop at } \\
\text { the stop sign and slid } \\
\text { sideways on the ice. Vehicle } \\
\text { made contact with a berm on } \\
\text { the opposite side of the road, } \\
\text { causing the vehicle to flip } \\
\text { over and land on it's top. } \\
\text { Driver received minor } \\
\text { laceration to his hand and the } \\
\text { passenger was not injured. }\end{array}$ \\
\hline
\end{tabular}


Appendix B-2

CY 1995 Recordable Government Vehicle Accidents

\begin{tabular}{|c|c|c|c|l|}
\hline Date & \$ Amount & Area & $\begin{array}{c}\text { Organization } \\
\text { Code }\end{array}$ & \multicolumn{1}{c|}{$\begin{array}{c}\text { Description of } \\
\text { Accident }\end{array}$} \\
\hline $12 / 20 / 95$ & $\$ 1,038$ & $\begin{array}{c}3080 \text { George } \\
\text { Washington Way } \\
\text { Parking Lot } \\
\text { Richland }\end{array}$ & $8 \mathrm{P560}$ & $\begin{array}{l}\text { It was dark and the driver } \\
\text { was entering the parking lot. } \\
\text { He failed to see the } \\
\text { protruding area containing } \\
\text { some landscaping rocks. He } \\
\text { ran over the curb and the } \\
\text { vehicle made contact with a } \\
\text { large rock resulting in } \\
\text { damage to the passenger side } \\
\text { rocker panels. The driver } \\
\text { was not injured. }\end{array}$ \\
\hline
\end{tabular}


Page No. 1

02/07/96

SKIN CONTAMINATIONS

OCCURRING IN WHC-MANAGED FACILITIES DURING CY 1995

\section{Report- Report \# \\ able Date.

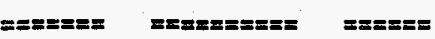 \\ Facility \\ \& Building Craft

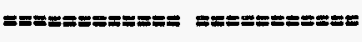

Maximum

Activity

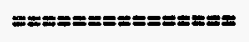

First

Detected Location

m=em=z=

m=z=m=m

950112

SCR-95-013 8E4

950113

SCR-95-010 1722

950127

$?$

950201

15370

sch-95-014

950206

38710

PUREX

SCR-95-015 87422

950209

SCR-95-016 8E4

950222

SCR- 95

950302

SCR-95-020 15400
950407

SCR-95-022 1532

950412

$F$

C-CR FARM

AMAL LABS

2225

202A

PFP

$234-5$

PFP

234-5

$$
\text { 271-T }
$$

2225

K BASIN

105KE

PFP

234-5

PFP

232-2

HPT

CHEM TECH

MUCL OPER

LOCKSMITH

5000

DPN BC

SELF

3000

DPM BG

PCN

5000

DPM BG

HPT

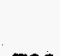

DPM A

SELF

420

DPM A

HPT

HAND

NUCL OPER

6000

DPM BC

HPT

FACE

CHEM TECH

10000

DPM BG

ARM

MUCL OPER

1000

DPM

CHEM TECH

2000

DPM A

SELF

NUCL OPER

750

DPM A

HPT

BODY

$\begin{array}{lllll}\text { ELECTRICIAN } 5000 & \text { DPM BG } & \text { HPT } & \text { ARM }\end{array}$

PLANT

221-T

the

87490 
Page No. 2

$02 / 07 / 96$

$$
\text { SKIN CONTAMINATIONS }
$$

OCCURRING IN WHC-MAMAGED FACILITIES DURING CY 1995

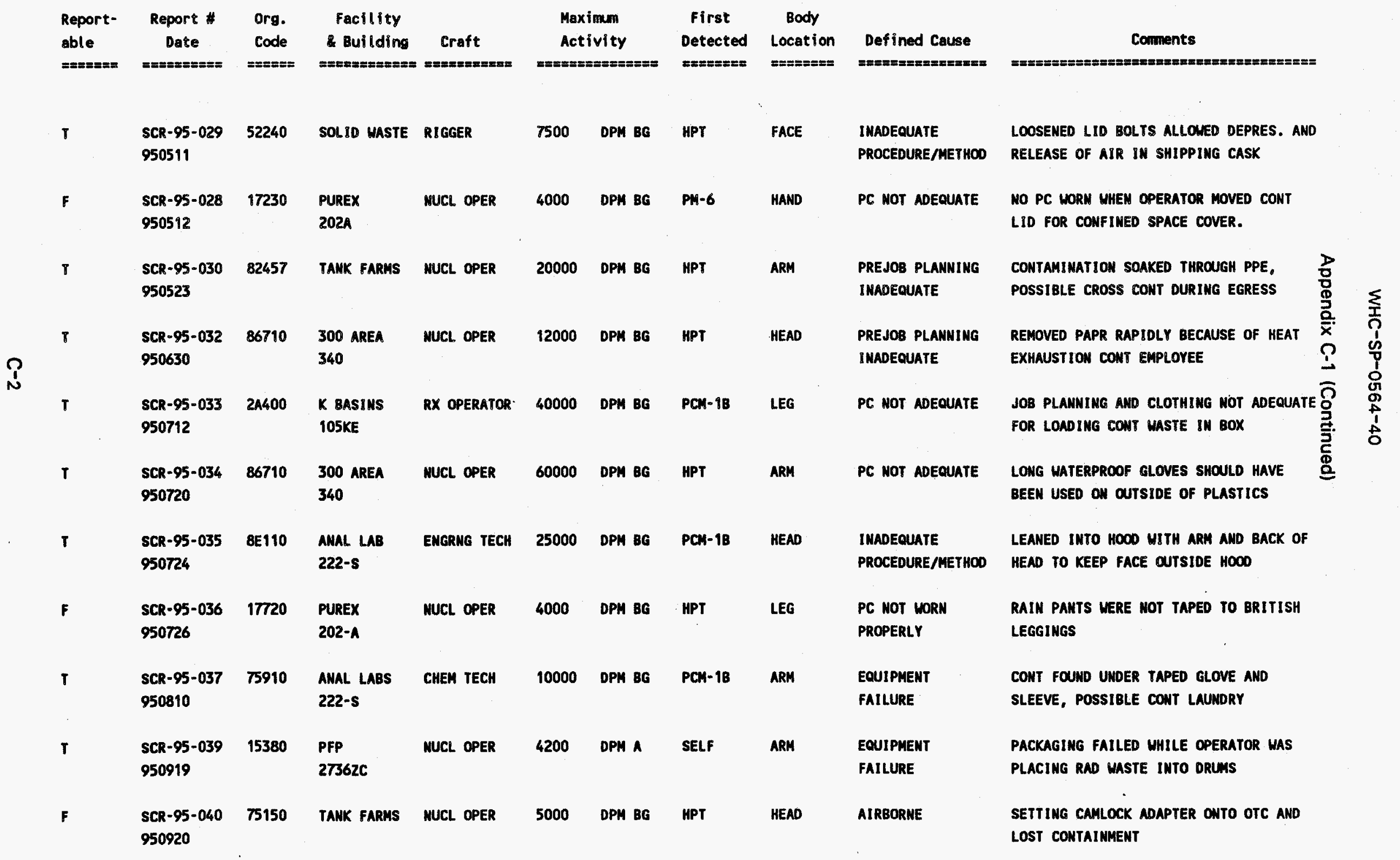


Page No. 3

02/07/96

SKIN CONTAMIMATIONS

OCCURRING IN WHC-MANAGED FACILITIES DURING CY 1995

Report- Report * Org. Facility

able Date Code \& Bullding Craft

Maximum, First Body

Activity Detected Location Defined Cause

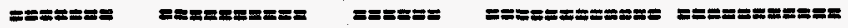

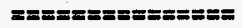

=xs=x==:

$== \pm== \pm=$

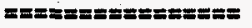

Comments

$\begin{array}{lllllll}\text { SCR-95-042 } 17850 \text { PUREX PLUMBER } & 1500 & \text { DPM BG HPT }\end{array}$

950922

SCR-95-044 77140 TANK FARMS ENGIMEER

951004

241-AN

T SCR-95-046

951019

75753

ANAL LABS

2225

SCR-95-050 $33920 \quad$ PFP

951023

SCR-95-052

951023

15370

$232-2$

PFP

$232-2$

SCR-95-056 5B200 K BASINS

951108

105KE

SCR-95-059 75766 AMAL LABS

951218
$222-5$
OTHER, UNKNOWN, NO SOURCE DETECTED IN FOLLOW-UP SURVEY Misc.

NONE PROVIDED

No CAUSE PROVIDED, HANDLING PRESSURE TEST MANIFOLD

PROTECTIVE RUBBER STOPPER DEGRADED WHEN OPENED CLOTHING FAILURE DOING SAMPLE STD. IN HOOD

POSSIBLE CONT ON HANDLING BAGGED MASTE

FLOOR

AIRBORNE

HANDLING BAGGED WASTE

PREJOB PLANNING

IMADEQUATE

INSTALLING NEW PIPING AND VALVING INVOLVING DRILLING

CONT FOUND INSIDE HOOO 5, PROBABLE CAUSE - UNDRESS AND TOUCHING SKIN 
Page No. 1

02/07/96

CLOTHING CONTAMINATIONS

OCCURRING IN WHC-MANAGED FACILITIES DURING CY 1995

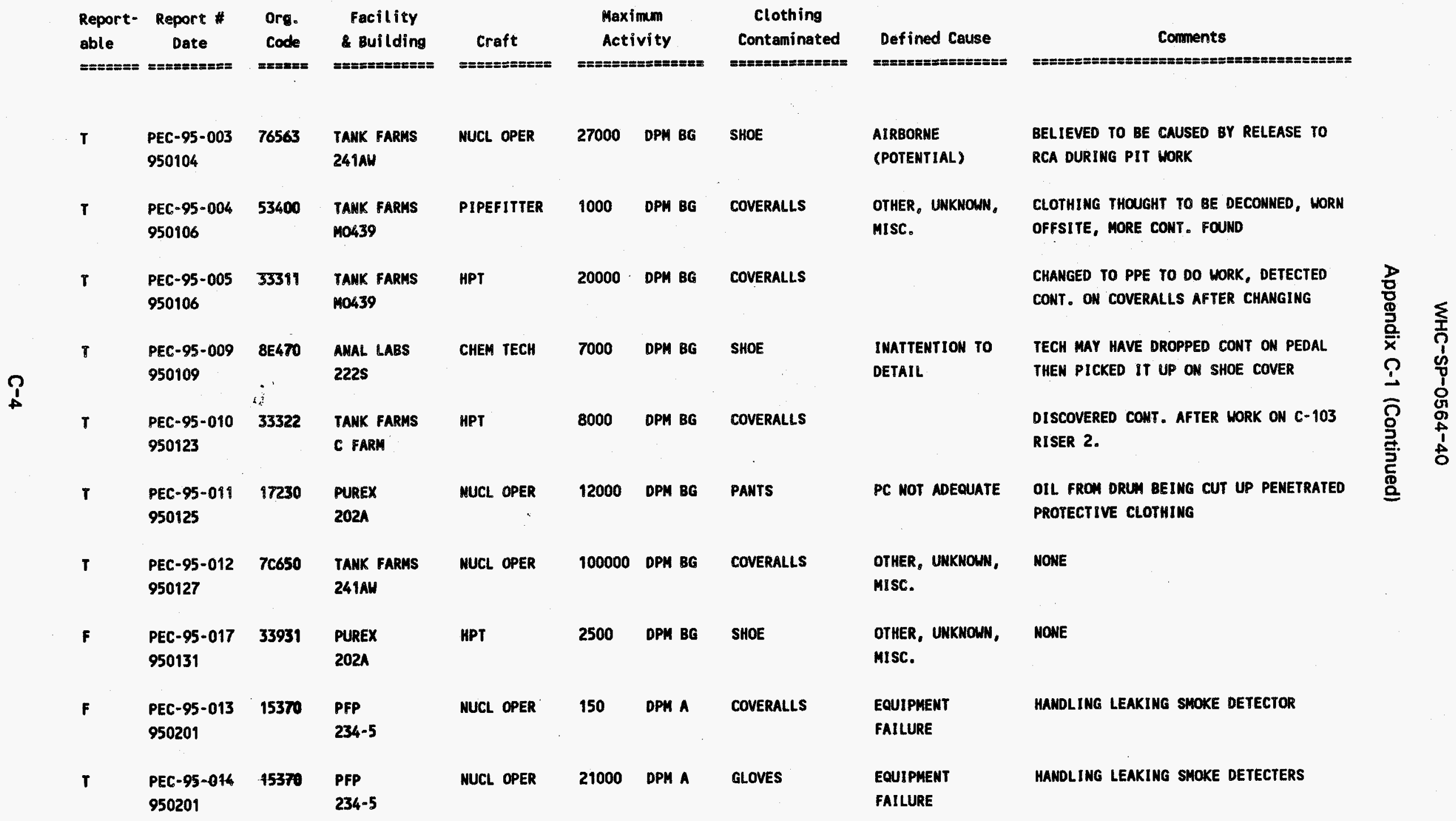


Page No. 2

02/07/96

CLOTHING CONTAMINATIONS

OCCURRING IN HHC-MANAGED FACILITIES DURING CY 1995

\begin{tabular}{|c|c|c|c|c|c|c|c|c|c|}
\hline $\begin{array}{l}\text { Report- } \\
\text { able } \\
=== \pm==\end{array}$ & $\begin{array}{c}\text { Report \# } \\
\text { Date } \\
========m=\end{array}$ & $\begin{array}{l}\text { Org. } \\
\text { Code } \\
=m=m==\end{array}$ & $\begin{array}{c}\text { Facility } \\
\text { Building } \\
====x==x===\end{array}$ & $\begin{array}{c}\text { Craft } \\
====== \pm==\end{array}$ & $\begin{array}{r}\text { Max } \\
\text { Act } \\
====-\end{array}$ & $\begin{array}{l}\text { mum } \\
\text { vity } \\
======\end{array}$ & $\begin{array}{c}\text { Clothing } \\
\text { Contaminated } \\
== \pm= \pm x=== \pm=\end{array}$ & $\begin{array}{l}\text { Defined Cause } \\
\text { ==:=:==:=:=:==:==: }\end{array}$ & 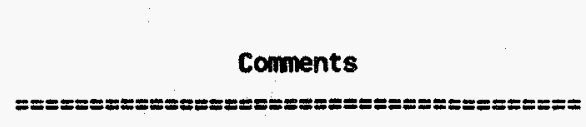 \\
\hline $\mathbf{F}$ & $\begin{array}{l}\text { PEC- } 95-016 \\
950202\end{array}$ & 58000 & $\begin{array}{l}\text { K BASINS } \\
105 \mathrm{KH}\end{array}$ & I RONWORKER & 5000 & DPH BG & $\begin{array}{l}\text { MOOESTY } \\
\text { CLOTHING }\end{array}$ & $\begin{array}{l}\text { OTHER, UNKNOWN, } \\
\text { MISC. }\end{array}$ & POSSIBLE CONTAMIMATED LAUNDRY \\
\hline $\mathbf{T}$ & $\begin{array}{l}\text { PEC- } 95-018 \\
950209\end{array}$ & 58200 & $\begin{array}{l}\text { K BASIMS } \\
\text { 105KE }\end{array}$ & IRONWORKER & 8000 & DPM BG & SHIRT & PC NOT ADEQUATE & $\begin{array}{l}\text { WHILE TRYING TO FIT TOOL INTO AREA WAS } \\
\text { FORCED TO RUB AGAINST WALL. }\end{array}$ \\
\hline $\mathbf{F}$ & $\begin{array}{l}\text { PEC-95-020 } \\
950210\end{array}$ & 80450 & $\begin{array}{l}\text { ANAL LABS } \\
2225\end{array}$ & CHEM TECH & 2856 . & DPM BG & PANTS & PC FAILURE & \\
\hline $\mathbf{T}$ & $\begin{array}{l}\text { PEC-95-021 } \\
950213\end{array}$ & $8 E 410$ & ANAL LABS & CHEN TECH & 10000 & DPM BG & PANTS & PC FAILURE & $\begin{array}{l}\text { SUSPECTED CONT LAUNDRY, OTHER LAUNDRY } \\
\text { SURVEYED AND CONT FOUND }\end{array}$ \\
\hline $\mathbf{T}$ & $\begin{array}{l}\text { PEC-95-022 } \\
950224\end{array}$ & $7 \mathrm{c620}$ & $\begin{array}{l}\text { TANK FARMS } \\
2704 \mathrm{HV}\end{array}$ & NUCL OPER & 4000 & DPM BG & COAT & $\begin{array}{l}\text { OTHER, UNKMOWN, } \\
\text { MISC }\end{array}$ & $\begin{array}{l}\text { PERSONAL COAT CONT IN CHANGE ROOM } \\
\text { OUTSIDE RAD AREA }\end{array}$ \\
\hline $\mathbf{T}$ & $\begin{array}{l}\text { PEC- } 95-030 \\
950321\end{array}$ & $7 \mathrm{C620}$ & $\begin{array}{l}\text { TANK FARMS } \\
\text { U FARM }\end{array}$ & NUCL OPER & 25000 & DPM BG & $\begin{array}{l}\text { MODESTY } \\
\text { CLOTHING }\end{array}$ & $\begin{array}{l}\text { OTHER, UNKNOWN, } \\
\text { MISC. }\end{array}$ & $\begin{array}{l}\text { OTHER MANAGEMENT PROBLEM, NOT } \\
\text { DETERMINED }\end{array}$ \\
\hline $\mathbf{F}$ & $\begin{array}{l}\text { PEC-95-034 } \\
950322\end{array}$ & $7 \mathrm{C563}$ & TANK FARMS & NUCL OPER & 1500 & DPM BG & GLOVES & $\begin{array}{l}\text { OTHER, UNKNOWN, } \\
\text { MISC }\end{array}$ & NO EXPLANATION GIVEN \\
\hline $\mathbf{F}$ & $\begin{array}{l}\text { PEC- } 95-033 \\
950322\end{array}$ & $7 C 562$ & TANK FARMS & NUCL OPER & 1500 & DPH BG & GLOVES & $\begin{array}{l}\text { OTHER, UNKNOWN, } \\
\text { MISC }\end{array}$ & $\begin{array}{l}\text { COVERALLS ALSO CONT, NO EXPLANATION } \\
\text { GIVEN }\end{array}$ \\
\hline $\mathbf{F}$ & $\begin{array}{l}\text { PEC-95-031 } \\
950323\end{array}$ & $5 A 300$ & TANK FARMS & LABORER & 4000 & DPM BG & BOOT & $\begin{array}{l}\text { EQUIPMENT } \\
\text { FAILURE }\end{array}$ & $\begin{array}{l}\text { LOST RUBBER SHOE COVER WHILE WORKING } \\
\text { IN WET CONDITIONS }\end{array}$ \\
\hline $\mathrm{r}$ & $\begin{array}{l}\text { PEC-95-032 } \\
950325\end{array}$ & $7 C 650$ & TANK FARMS & NUCL OPER & 25000 & DPM BG & COVERALLS & PC FAILURE & $\begin{array}{l}\text { POSSIBLE CONT LAUNDRY, OUTER } 2 \text { PAIR OF } \\
\text { PPE NOT CONT }\end{array}$ \\
\hline
\end{tabular}


Page No. 3

$02 / 07 / 96$

CLOTHING CONTAMINATIONS

OCCURRING IN WHC-MANAGED FACILITIES DURING CY 1995

\begin{tabular}{|c|c|c|c|c|c|c|c|c|c|}
\hline $\begin{array}{l}\text { Report- } \\
\text { able } \\
======\end{array}$ & $\begin{array}{l}\text { Report \# } \\
\text { Date } \\
========\end{array}$ & $\begin{array}{l}\text { Org. } \\
\text { Code } \\
====\end{array}$ & $\begin{array}{c}\text { Facility } \\
\text { \&uilding } \\
===== \pm=== \pm=\end{array}$ & $\begin{array}{c}\text { Craft } \\
=x== \pm= \pm== \pm=\end{array}$ & $\begin{array}{r}\text { Max } \\
\text { Act } \\
====\end{array}$ & $\begin{array}{l}\text { minn } \\
\text { vity } \\
==m=====\end{array}$ & $\begin{array}{l}\text { Clothing } \\
\text { Contaminated } \\
==-==-==-===\end{array}$ & $\begin{array}{l}\text { Defined Cause } \\
==========:=====\end{array}$ & 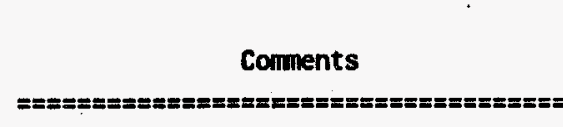 \\
\hline $\mathbf{T}$ & $\begin{array}{l}\text { PEC-95-038 } \\
950411\end{array}$ & 70620 & TANK FARMS & NUCL OPER & 30000 & DPM BG & COVERALLS & $\begin{array}{l}\text { EQUIPMENT } \\
\text { FAILURE }\end{array}$ & $\begin{array}{l}\text { A BAG FAILED WHILE PACKAGTNG WASTE, } \\
\text { CONTAMINATING CLOTHING }\end{array}$ \\
\hline $\mathbf{T}$ & $\begin{array}{l}\text { PEC-95-039 } \\
950411\end{array}$ & 23000 & TANK FARMS & RIGGER & 10000 & DPM BG & BOOT & $\begin{array}{l}\text { OTHER, UNKNOWN, } \\
\text { MISC }\end{array}$ & $\begin{array}{l}\text { ALSO RECEIVED SKIN CONTAMINATION TO } \\
\text { RIGHT KNEE }\end{array}$ \\
\hline $\mathbf{F}$ & $\begin{array}{l}\text { PEC-95-040 } \\
950411\end{array}$ & 33311 & $\begin{array}{l}\text { TANK FARMS } \\
241 \mathrm{~A}\end{array}$ & HPT & 3500 & DPM BG & BOOT & $\begin{array}{l}\text { PC NOT WORN } \\
\text { PROPERLY }\end{array}$ & PROTECTIVE CLOTHING NOT WORN PROPERLY \\
\hline $\mathrm{T}$ & $\begin{array}{l}\text { PEC-95-043 } \\
950422\end{array}$ & GELCO & $\begin{array}{l}\text { PFP } \\
234-52\end{array}$ & LABORER & 5600 & DPM A & BOOTS & $\begin{array}{l}\text { PROCEOURE } \\
\text { VIOLATION }\end{array}$ & INADEQUATE WORK INVIRONMENT \\
\hline $\mathbf{F}$ & $\begin{array}{l}\text { PEC-95-041 } \\
950425\end{array}$ & $2 A 440$ & $\begin{array}{l}\text { K BASINS } \\
\text { 105KE }\end{array}$ & OPERATOR & 500 & DPM BG & $\begin{array}{l}\text { MODESTY } \\
\text { CLOTHING }\end{array}$ & $\begin{array}{l}\text { INADEQUATE } \\
\text { PROCEDURE }\end{array}$ & $\begin{array}{l}\text { ALARMED PORTAL AFTER SPILL OF BASIN } \\
\text { WATER AT HP COUNTING STATION }\end{array}$ \\
\hline $\mathbf{F}$ & $\begin{array}{l}\text { PEC-95-042 } \\
950426\end{array}$ & 16530 & $\begin{array}{l}\text { B PLANT } \\
\text { 201B }\end{array}$ & ENGINEER & 2000 & DPM BG & SHOE & $\begin{array}{l}\text { OTHER, UNKNOWN, } \\
\text { MISC }\end{array}$ & CAUSE NOT DETERHINED \\
\hline $\mathbf{T}$ & $\begin{array}{l}\text { PEC-95-044 } \\
950428\end{array}$ & $5 A 380$ & $\begin{array}{l}\text { TANK FARMS } \\
2415 X\end{array}$ & FOREMAN & 10000 & DPM BG & JACKET & $\begin{array}{l}\text { OTHER, UNKNOWN, } \\
\text { MISC }\end{array}$ & $\begin{array}{l}\text { SMALL CONT PARTICLE BECAME LOOGED IN } \\
\text { THE COAT LINING, POSS. LAUNORY }\end{array}$ \\
\hline $\mathbf{T}$ & $\begin{array}{l}\text { PEC-95-045 } \\
950504\end{array}$ & $7 \mathrm{C5} 65$ & $\begin{array}{l}\text { TANK FARMS } \\
\text { 107AN }\end{array}$ & NUCL OPER & 6500 & DPM BG & SHOE & $\begin{array}{l}\text { OTHER, UNKNOWM, } \\
\text { MISC }\end{array}$ & $\begin{array}{l}\text { WORKER NEVER ENTERED COMTAIMMENT AND } \\
\text { WAS NOT INVOLVED IN MAINTEMANCE }\end{array}$ \\
\hline $\mathbf{T}$ & $\begin{array}{l}\text { PEC-95-046 } \\
950505\end{array}$ & 16950 & $\begin{array}{l}\text { B PLANT } \\
225-B\end{array}$ & SUPERVISOR & 20000 & DPM BG & SHOE & $\begin{array}{l}\text { OTHER, UHKHOWN, } \\
\text { MISC }\end{array}$ & $\begin{array}{l}\text { NO SOURCE OF CONTANINATION COULD BE } \\
\text { FOUND IN THE OPERATING GALLERY }\end{array}$ \\
\hline F & $\begin{array}{l}\text { PEC-95-048 } \\
950512\end{array}$ & 17230 & $\begin{array}{l}\text { PUREX } \\
202 A\end{array}$ & NUCL OPER & 2500 & DPH BG & SWEAT PANTS & $\begin{array}{l}\text { OTHER, UNKNOWN, } \\
\text { MISC }\end{array}$ & NONE PROVIDED. \\
\hline
\end{tabular}


Page No. 4

02/07/96

CLOTHING CONTAMINATIONS

OCCURRING IN WHC-MANAGED FACILITIES DURING CY 1995

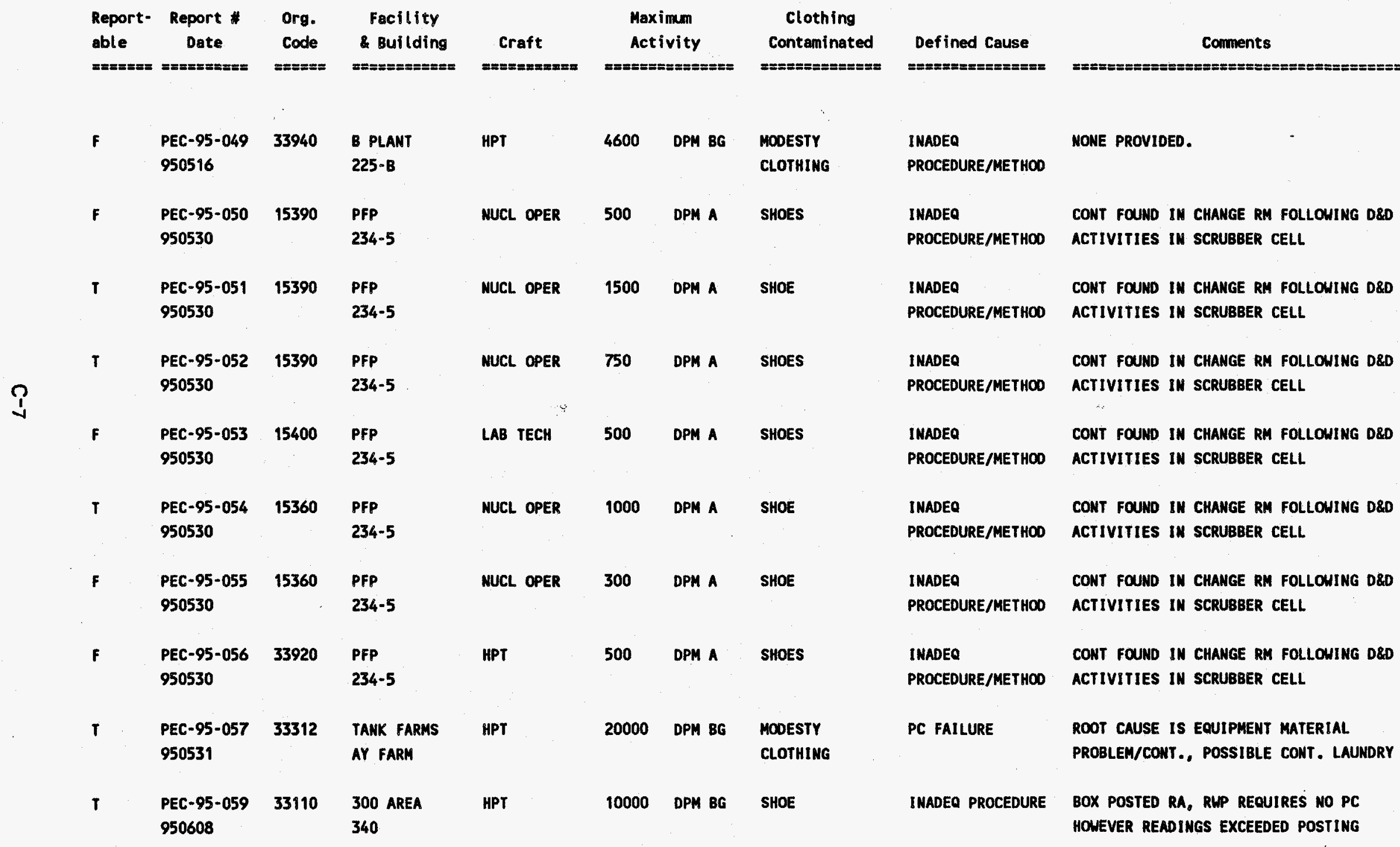


Page No. 5

02/07/96

CLOTHING CONTAMINATIONS

OCCURRING IN WHC-MANAGED FACILITIES DURING CY 1995

\begin{tabular}{|c|c|c|c|c|c|c|c|c|c|c|}
\hline $\begin{array}{l}\text { Report- } \\
\text { able } \\
\text { s====E }\end{array}$ & $\begin{array}{c}\text { Report \# } \\
\text { Dete } \\
\text { =m=-==-= }=\end{array}$ & $\begin{array}{l}\text { Org. } \\
\text { Code } \\
== \pm==\end{array}$ & $\begin{array}{l}\text { Facility } \\
\text { \&uilding } \\
=====\pi=== \pm\end{array}$ & $\begin{array}{c}\text { Craft } \\
== \pm= \pm=== \pm=\end{array}$ & $\begin{array}{r}\text { Max } \\
\text { Act } \\
== \pm==\end{array}$ & $\begin{array}{l}\text { mum } \\
\text { vity } \\
=======\end{array}$ & $\begin{array}{l}\text { Clothing } \\
\text { Contaminated } \\
\text { =eme=m }\end{array}$ & 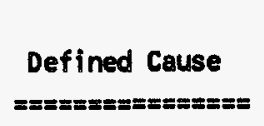 & 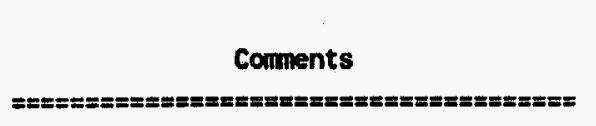 & \\
\hline T & $\begin{array}{l}\text { PEC-95-060 } \\
950623\end{array}$ & $2 A 450$ & $\begin{array}{l}\text { K BASINS } \\
\text { 105-KE }\end{array}$ & RX OPERATOR & 20000 & DPH BG & $\begin{array}{l}\text { MODESTY } \\
\text { CLOTHING }\end{array}$ & PC NOT ADEQUATE & $\begin{array}{l}\text { PCM DETECTED CONT WHEN EXYTING BUFFER } \\
\text { AREA }\end{array}$ & \\
\hline $\mathbf{T}$ & $\begin{array}{l}\text { PEC-95-061 } \\
950627\end{array}$ & 82231 & $\begin{array}{l}\text { T PLANT } \\
221-T\end{array}$ & MUCL OPER & 20000 & DPM BG & $\begin{array}{l}\text { MODESTY } \\
\text { CLOTHING }\end{array}$ & $\begin{array}{l}\text { OTHER, UNKNOWN, } \\
\text { MISC. }\end{array}$ & $\begin{array}{l}\text { NO CONT DETECTED ON PPE. SOURCE OF } \\
\text { CONT UNKNOWN }\end{array}$ & \\
\hline$F$ & $\begin{array}{l}\text { PEC-95-063 } \\
950712\end{array}$ & $7 \mathrm{C520}$ & $\begin{array}{l}\text { TANK FARMS } \\
\text { 106PX }\end{array}$ & MUCL OPER & 1500 & DPM BG & T-SHIRT & PC NOT ADEQUATE & SHIRT WAS WET WITH SWEAT & 뭄 \\
\hline $\mathbf{T}$ & $\begin{array}{l}\text { PEC-95-064 } \\
950714\end{array}$ & $7 C 550$ & TANK FARMS & MUCL OPER & 25000 & DPM 86 & MODESTY SHIRT & $\begin{array}{l}\text { OTHER, UNKNOWN, } \\
\text { MISC. }\end{array}$ & $\begin{array}{l}\text { UNKNOWN CAUSE, TRUCK EMPLOYEE DROVE } \\
\text { HAD NO CONT. }\end{array}$ & $\begin{array}{l}\bar{x} \\
? \\
1\end{array}$ \\
\hline T & $\begin{array}{l}\text { PEC-95-069 } \\
950814\end{array}$ & 77430 & TAHK FARMS & INSTRM TECH & 20000 & DPM 86 & SHOE & $\begin{array}{l}\text { EQUIPMENT } \\
\text { FAILURE }\end{array}$ & $\begin{array}{l}\text { SUSPECTED CONT SHOE COVERS FROH } \\
\text { LAUNDRY }\end{array}$ & $\begin{array}{l}\text { ᄋ } \\
\stackrel{2}{3}\end{array}$ \\
\hline$F$ & $\begin{array}{l}\text { PEC-95-067 } \\
950821\end{array}$ & SUBCTR & $\begin{array}{l}\text { T PLANT } \\
221-T\end{array}$ & ROOFER & 4000 & DPM BG & GLOVE & $\begin{array}{l}\text { OTHER, UNKNOWN, } \\
\text { MISC. }\end{array}$ & $\begin{array}{l}\text { WHILE REMOVING OLD ROOFING MATERIAL, } \\
\text { CONT FOUND IN DISTURBED MATERIAL }\end{array}$ & $\stackrel{8}{2}$ \\
\hline $\mathbf{F}$ & $\begin{array}{l}\text { PEC-95-068 } \\
950830\end{array}$ & 15370 & $\begin{array}{l}\text { PFP } \\
273628\end{array}$ & MUCL OPER & 1500 & DPM A & GLOVES & $\begin{array}{l}\text { INADEQUATE WORK } \\
\text { ENVIRON }\end{array}$ & $\begin{array}{l}\text { CONT ON OUTSIDE OF DRUMS BEING MOVED } \\
\text { CAUSED GLOVE CONT }\end{array}$ & \\
\hline $\boldsymbol{T}$ & $\begin{array}{l}\text { PEC-95-070 } \\
950907\end{array}$ & 57E00 & $\begin{array}{l}\text { K BASInS } \\
\text { 105KE }\end{array}$ & ENGINEER & 10000 & DPM BG & MOOESTY SHIRT & $\begin{array}{l}\text { EQUIPMENT } \\
\text { FAILURE }\end{array}$ & $\begin{array}{l}\text { SUSPECTED CONT LAUNDRY DUE TO CONT } \\
\text { BEING COBALT-60, NOT TYPICAL OF } K\end{array}$ & \\
\hline $\mathbf{T}$ & $\begin{array}{l}\text { PEC-95-071 } \\
950911\end{array}$ & 77260 & $\begin{array}{l}\text { TANK FARMS } \\
241 T \text { FARM }\end{array}$ & MUCL OPER & 9500 & DPH BG & SHOE & UNDRESSING & $\begin{array}{l}\text { LIKELY THAT SPECK WAS PICKED UP FROM } \\
\text { STEP-OFF PAD WHILE UNDRESSING }\end{array}$ & \\
\hline $\mathbf{T}$ & $\begin{array}{l}\text { PEC-95-072 } \\
950919\end{array}$ & 15380 & $\begin{array}{l}\text { PFP } \\
2736-2 C\end{array}$ & MUCL OPER & 700 & DPM A & COVERALLS & $\begin{array}{l}\text { EQUIPMENT } \\
\text { FAILURE }\end{array}$ & $\begin{array}{l}\text { RAD WASTE PACKAGING LEAKED WHILE BEING } \\
\text { LOADED INTO DRUMS }\end{array}$ & \\
\hline
\end{tabular}


Page No. 6

02/07/96

CLOTHIMG CONTAMINATIONS

OCCURRING IN WHC-MAMAGED FACILITIES DURING CY 1995

\begin{tabular}{|c|c|c|c|c|c|c|c|c|c|c|}
\hline $\begin{array}{l}\text { Report- } \\
\text { able } \\
== \pm== \pm=\end{array}$ & $\begin{array}{c}\text { Report * } \\
\text { Oate } \\
=m=m= \pm=m=m\end{array}$ & $\begin{array}{l}\text { Org. } \\
\text { Code } \\
=\text { = }=9=1=\end{array}$ & $\begin{array}{l}\text { Facility } \\
\text { Building }\end{array}$ & Craft & $\begin{array}{r}\text { Max } \\
\text { Act } \\
==-=0\end{array}$ & $\begin{array}{l}\text { mum } \\
\text { vity } \\
== \pm===\end{array}$ & $\begin{array}{l}\text { Clothing } \\
\text { Contaminated } \\
\text { m=E=E= }\end{array}$ & $\begin{array}{l}\text { Defined Cause } \\
m==m== \pm=x= \pm=x==\end{array}$ & 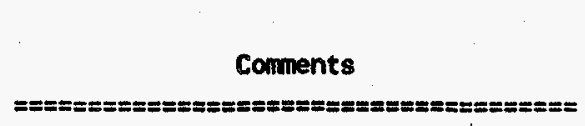 & \multirow{11}{*}{ 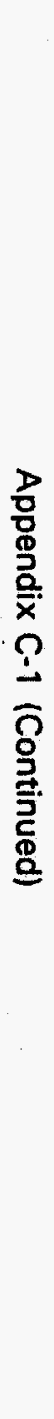 } \\
\hline $\mathbf{T}$ & $\begin{array}{l}\text { PEC- } 95-073 \\
950920\end{array}$ & 15360 & $\begin{array}{l}\text { PFP } \\
291-2\end{array}$ & NUCL OPER & 6300 & DPM A & SHOE & $\begin{array}{l}\text { INADEQUATE WORK } \\
\text { ENVIRON }\end{array}$ & $\begin{array}{l}\text { SOURCE OF CONT MAS PEELING PAINT FROM } \\
\text { PREVIOUS DECON WORK }\end{array}$ & \\
\hline $\mathbf{F}$ & $\begin{array}{l}\text { PEC-95-074 } \\
950920\end{array}$ & $3 E 120$ & TANK FARMS & HPT & 2500 & DPM BG & SHOE & $\begin{array}{l}\text { OTHER, UNKNOWN, } \\
\text { MISC. }\end{array}$ & NO CONT FOUND IN SX CHANGE TRAILER & \\
\hline $\mathbf{T}$ & $\begin{array}{l}\text { PEC-95-075 } \\
950920\end{array}$ & 75150 & $\begin{array}{l}\text { TANK FARMS } \\
\text { SX-108 }\end{array}$ & NUCL OPER & 15000 & DPM BG & T SHIRT & AIRBORNE & $\begin{array}{l}\text { LOST CONTAINMENT WHEN SETTING CAMLOCK } \\
\text { ADAPTER ONTO OTC }\end{array}$ & \\
\hline$F$ & $\begin{array}{l}\text { PEC- } 95-076 \\
950922\end{array}$ & $5 F 680$ & $\begin{array}{l}\text { ANAL LABS } \\
222-S\end{array}$ & LABORER & 4000 & DPM BG & SHORTS & PC FAILURE & $\begin{array}{l}\text { DUE TO HEAT OUTSIDE, SWEAT WICKED } \\
\text { THROUGH PC }\end{array}$ & \\
\hline $\mathbf{T}$ & $\begin{array}{l}\text { PEC- } 95-078 \\
950929\end{array}$ & 3E130 & $\begin{array}{l}\text { ANAL LABS } \\
222-S\end{array}$ & HPT & 45000 & DPM BG & JEANS & $\begin{array}{l}\text { OTHER, UNKNOWH, } \\
\text { MISC. }\end{array}$ & $\begin{array}{l}\text { EMPLOYEE NEVER ENTERED CONT AREA, } \\
\text { SOURCE OF CONT NOT FOUHD }\end{array}$ & \\
\hline $\mathbf{T}$ & $\begin{array}{l}\text { PEC-95-077 } \\
951001\end{array}$ & 77290 & $\begin{array}{l}\text { TANK FARM } \\
241-T-107\end{array}$ & MANAGER & 80000 & DPM BG & JACKET, PANTS & $\begin{array}{l}\text { OTHER, UNKHOWN, } \\
\text { MISC. }\end{array}$ & $\begin{array}{l}\text { CONT FROM 107-T PUMP PIT, NO CAUSE } \\
\text { GIVEN, also cont skin SCR-95-043 }\end{array}$ & \\
\hline $\mathbf{T}$ & $\begin{array}{l}\text { PEC-95-079 } \\
951004\end{array}$ & $771 A^{3}$ & $\begin{array}{l}\text { TANK FARMS } \\
\text { AY FARM }\end{array}$ & PIPEFITTER & 30000 & DPM BG & GLOVES, SHOES & $\begin{array}{l}\text { OTHER, UNKNOWN, } \\
\text { MISC. }\end{array}$ & $\begin{array}{l}\text { RECEIVED CONT WHILE PRESSURE TESTING } \\
\text { TRANSFER LINE SN-247 }\end{array}$ & \\
\hline $\mathbf{T}$ & $\begin{array}{l}\text { PEC-95-080 } \\
951010\end{array}$ & 75753 & $\begin{array}{l}\text { ANAL LABS } \\
2225\end{array}$ & CHEMIST & 35000 & DPM BG & SHOE & PC NOT ADEQUATE & $\begin{array}{l}\text { CONT SHOE HAD GUMYY SUBSTANCE MITH SM } \\
\text { GRAVEL IMBEDDED UNDER SHOE COVER }\end{array}$ & \\
\hline F & $\begin{array}{l}\text { PEC-95-081 } \\
951012\end{array}$ & $2 A 620$ & $\begin{array}{l}\text { K BASINS } \\
\text { M05KW }\end{array}$ & IRONHORKER & 4500 & DPM BG & SHOE & $\begin{array}{l}\text { OTHER, UNKNOWN, } \\
\text { MISC. }\end{array}$ & NONE GIVEN & \\
\hline $\mathbf{T}$ & $\begin{array}{l}\text { PEC- } 95-082 \\
951017\end{array}$ & 77210 & $\begin{array}{l}\text { TANK FARMS } \\
2415 \& 5 X\end{array}$ & MUCL OPER & 15000 & DPM BG & socks & $\begin{array}{l}\text { PREJOB PLANNING } \\
\text { INADEQ }\end{array}$ & $\begin{array}{l}\text { CONT ALSO ON SKIN AFTER INSPECTING OLD } \\
\text { WATER LANCE, PREJOB PLAN INADEQ }\end{array}$ & \\
\hline
\end{tabular}


Page No. 7

$02 / 07 / 96$

CLOTHING CONTAMINATIONS

OCCURRING IN WHC-MANAGED FACILITIES DURING CY 1995

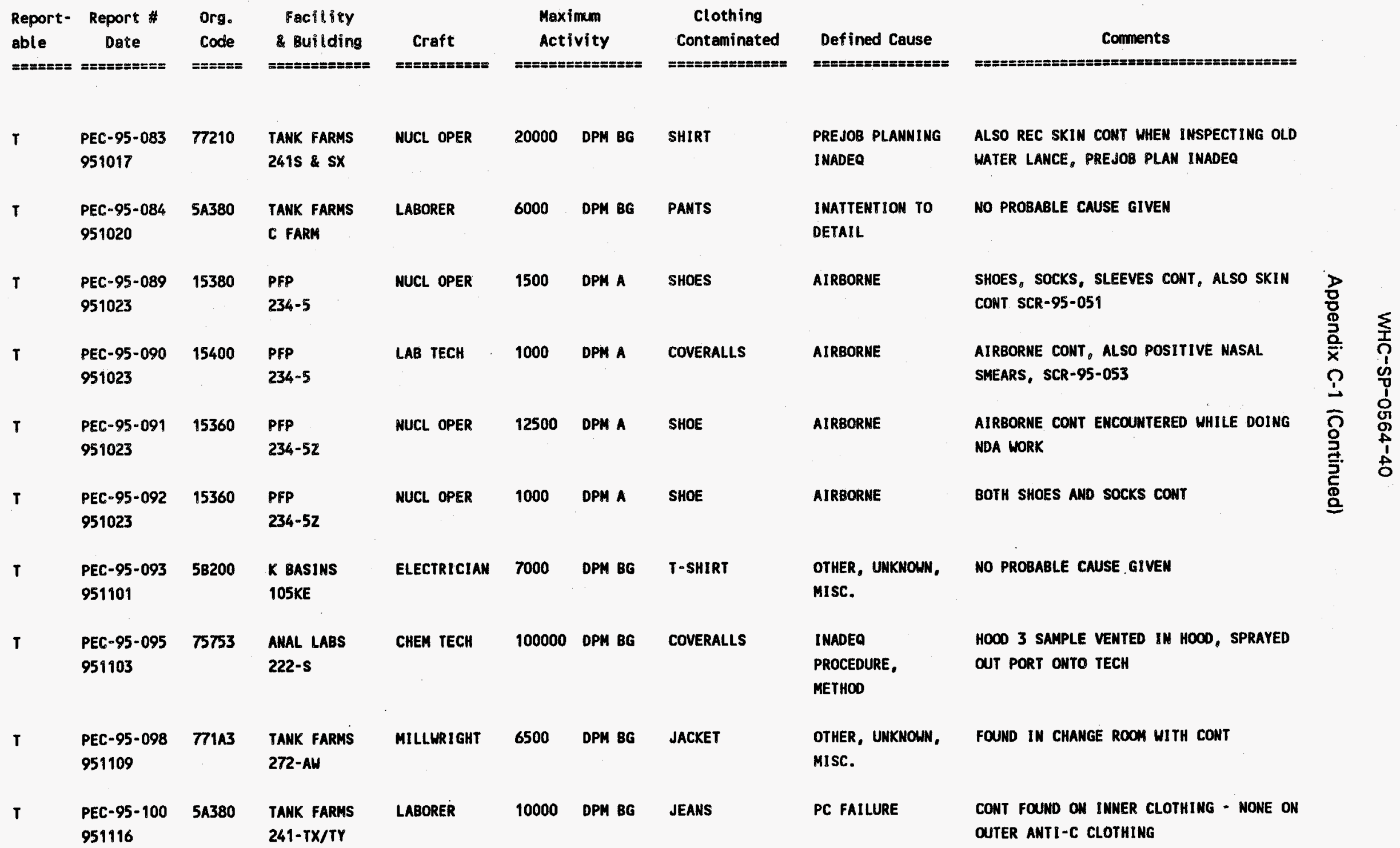




\begin{tabular}{|c|c|c|c|c|c|c|c|c|c|}
\hline $\begin{array}{l}\text { Report- } \\
\text { able } \\
=====\end{array}$ & $\begin{array}{c}\text { Report \# } \\
\text { Date } \\
========\end{array}$ & $\begin{array}{l}\text { Org. } \\
\text { Code } \\
== \pm== \pm\end{array}$ & $\begin{array}{c}\text { Facility } \\
\text { \&uilding } \\
\text { =E==:===: }\end{array}$ & $\begin{array}{c}\text { Craft } \\
====== \pm== \pm=\end{array}$ & $\begin{array}{r}\text { Maxil } \\
\text { Acti } \\
=m== \pm==\end{array}$ & $\begin{array}{l}\text { mity } \\
\text { vity } \\
=====\end{array}$ & $\begin{array}{l}\text { Clothing } \\
\text { Contaminated } \\
====== \pm==\end{array}$ & 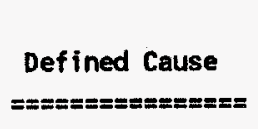 & 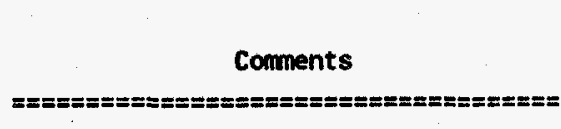 \\
\hline$T$ & $\begin{array}{l}\text { PEC-95-099 } \\
951116\end{array}$ & $5 F 680$ & $\begin{array}{l}\text { ANAL LABS } \\
222-S\end{array}$ & LABORER & 200000 & DPM BG & PANTS & PC FAILURE & $\begin{array}{l}\text { LABORER KNEELED DOWN AND RIPPED } \\
\text { PLASTIC COVERLALS ON CONCRETE }\end{array}$ \\
\hline $\mathbf{F}$ & $\begin{array}{l}\text { PEC }-95-113 \\
951120\end{array}$ & 77210 & $\begin{array}{l}\text { TANK FARMS } \\
104-5 X\end{array}$ & NUCL OPER & 4000 & DPM BG & SHIRT & PC NOT ADEQUATE & NONE GIVEN \\
\hline $\mathbf{T}$ & $\begin{array}{l}\text { PEC- } 95-105 \\
951128\end{array}$ & 75766 & $\begin{array}{l}\text { ANAL LABS } \\
222-S\end{array}$ & CHEM TECH & 40000 & DPM $8 G$ & PEN & $\begin{array}{l}\text { OTHER, UNKNOWN, } \\
\text { MISC. }\end{array}$ & $\begin{array}{l}\text { NO PROBABLE CAUSE GIVEN FOR RECEIVING } \\
\text { CONT TO PEN ON LANYARD }\end{array}$ \\
\hline $\mathbf{F}$ & $\begin{array}{l}\text { PEC-95-104 } \\
951201\end{array}$ & 75150 & $\begin{array}{l}\text { TANK FARMS } \\
2101 \mathrm{HV}\end{array}$ & NUCL OPER & 1000 & DPM BG & GLOVE & $\begin{array}{l}\text { INADEQ } \\
\text { PROCEDURE-METHOD }\end{array}$ & $\begin{array}{l}\text { LOOSE SURFACE CONT ON AUGER SLEEVE } \\
\text { SECTION OPERATOR HANDLED }\end{array}$ \\
\hline $\mathbf{T}$ & $\begin{array}{l}\text { PEC- } 95-107 \\
951215\end{array}$ & $16 A 20$ & $\begin{array}{l}\text { B PLANT } \\
221-B\end{array}$ & ELECTRICIAN & 7000 & DPM BG & SHORTS & PC FAILURE & $\begin{array}{l}\text { CONT FOUND AFTER DOING RELAMPING ON } \\
\text { CANYON CRANE }\end{array}$ \\
\hline$T$ & $\begin{array}{l}\text { PEC-95-108 } \\
951218\end{array}$ & 77140 & $\begin{array}{l}\text { TANK FARMS } \\
\text { M0439 }\end{array}$ & NUCL OPER & 350000 & DPM BG & SWEATSHIRT & $\begin{array}{l}\text { OTHER, UNKNOWN, } \\
\text { MISC. }\end{array}$ & $\begin{array}{l}\text { CONT MAY HAVE COME FROM THE USED } \\
\text { LAUNORY OPERATOR WAS LOADING }\end{array}$ \\
\hline$T$ & $\begin{array}{l}\text { PEC-95-110 } \\
951219\end{array}$ & $3 E 120$ & $\begin{array}{l}\text { TANK FARMS } \\
241-B X\end{array}$ & HPT & 8000 & DPM BG & SHIRT & PC NOT ADEQUATE & $\begin{array}{l}\text { CONT FOUND UHEN EXITING 106-BX TANK } \\
\text { FARM, PC INADEQUATE }\end{array}$ \\
\hline $\mathbf{T}$ & $\begin{array}{l}\text { PEC-95-111 } \\
951222\end{array}$ & 33541 & $\begin{array}{l}\text { T PLANT } \\
271-T\end{array}$ & HPT & 40000 & DPM BG & SHOE, SHIRT & UNDRESSING & $\begin{array}{l}\text { CONT PROBABLY TRANSFERRED DURING } \\
\text { UNBAGGING OF INSTRUMENTS }\end{array}$ \\
\hline $\mathbf{T}$ & $\begin{array}{l}\text { PEC-95-112 } \\
951227\end{array}$ & $5 F 680$ & $\begin{array}{l}\text { ANAL LABS } \\
2225\end{array}$ & LABORER & 8000 & DPN BG & $\begin{array}{l}\text { THERMAL } \\
\text { UNDERWEAR }\end{array}$ & $\begin{array}{l}\text { OTHER, UNKNOWN, } \\
\text { MISC. }\end{array}$ & $\begin{array}{l}\text { NO CONT FOUND ON SHIRT AND COVERALLS } \\
\text { NORN OVER UNDERWEAR }\end{array}$ \\
\hline
\end{tabular}


WHC-SP-0564-40

This page intentionally left blank.

$\mathrm{C}-12$ 


\section{GLOSSARY}

ABBREVIATIONS, ACRONYMS, AND INITIALISMS

\begin{tabular}{|c|c|}
\hline $\begin{array}{l}\text { ALARA } \\
\text { APC } \\
\text { APM } \\
\text { APO } \\
\text { ARA } \\
\text { AMW } \\
\text { ANSI } \\
\text { ATAMS } \\
\text { BBST } \\
\text { BCS } \\
\text { BCSR } \\
\text { BHI } \\
\text { BLS } \\
\text { CA } \\
\text { CAIRS } \\
\text { CAM } \\
\text { CAS } \\
\text { CCIP } \\
\text { CEDE } \\
\text { CFO } \\
\text { CM } \\
\text { CSO } \\
\text { CTD } \\
\text { CY } \\
\text { CYTD } \\
\text { D\&D } \\
\text { DORITE } \\
\text { DTPA } \\
\text { DOE } \\
\text { DOE-HO } \\
\text { DOE-RL } \\
\text { DOP } \\
\text { DPETS } \\
\text { ECD } \\
\text { ERO } \\
\text { ESO } \\
\text { EWP } \\
\text { FCA } \\
\text { FFTF } \\
\text { FMEF } \\
\text { FY } \\
\text { FYTD } \\
\text { GERT } \\
\text { GOCO } \\
\text { HAMTC } \\
\text { HEHF } \\
\text { HCA } \\
\text { HEPA } \\
\text { HGET } \\
\text { HLAN }\end{array}$ & $\begin{array}{l}\text { As Low As Reasonably Achievable } \\
\text { Accident Prevention Council } \\
\text { ALARA Protective Measures } \\
\text { ALARA Program Office } \\
\text { Airborne Radioactivity Area } \\
\text { ALARA Management Worksheet } \\
\text { American National Standards Institute } \\
\text { ALARA Tracking and Management System } \\
\text { Behavioral-Based Safety Training } \\
\text { BCS Richland, Incorporated (60000) } \\
\text { BCS Richland, Incorporated } \\
\text { Bechtel National, Incorporated } \\
\text { Bureau of Labor Statistics } \\
\text { Contamination Area } \\
\text { Computerized Accident/lncident Reporting System } \\
\text { Continuous Air Monitor } \\
\text { Central Alarm System } \\
\text { Contamination Control Improvement Project } \\
\text { Committed Effective Dose Equivalent } \\
\text { Administration (Chief Financial Officer) (40000) } \\
\text { Controlled Manual } \\
\text { Cognizant Secretarial Office } \\
\text { Cumulative Trauma Disorder } \\
\text { Calendar Year } \\
\text { Calendar Year to Date } \\
\text { Decontamination and Decommissioning } \\
\text { Define, Observe, Record, Intervene, Test, Evaluate } \\
\text { Diethylenetriaminepentaacetate } \\
\text { U. S. Department of Energy } \\
\text { U. S. Department of Energy - Headquarters } \\
\text { U. S. Department of Energy - Richland Operations Office } \\
\text { Disecoctyl Phthalate } \\
\text { Daily Personnel Exposure Tracking System } \\
\text { Estimated Completion Date } \\
\text { Environmental Restoration Operations } \\
\text { Emergency, Safety, and Quality Assurance Department (30000) } \\
\text { Enhanced Work Plan } \\
\text { Fixed Contamination Area } \\
\text { Fast Flux Test Facility } \\
\text { Fuels and Materials Examination Facility } \\
\text { Fiscal Year } \\
\text { Fiscal Year to Date } \\
\text { General Employee Radiological Training } \\
\text { Government Owned, Contractor Operated } \\
\text { Hanford Atomic Metal Trades Council } \\
\text { Hanford Environmental Health Foundation } \\
\text { High Contamination Area } \\
\text { High Efficiency Particulate Air (filter) } \\
\text { Hanford General Employee Training } \\
\text { Hanford Local Area Network }\end{array}$ \\
\hline
\end{tabular}




\section{GLOSSARY (Continued)}

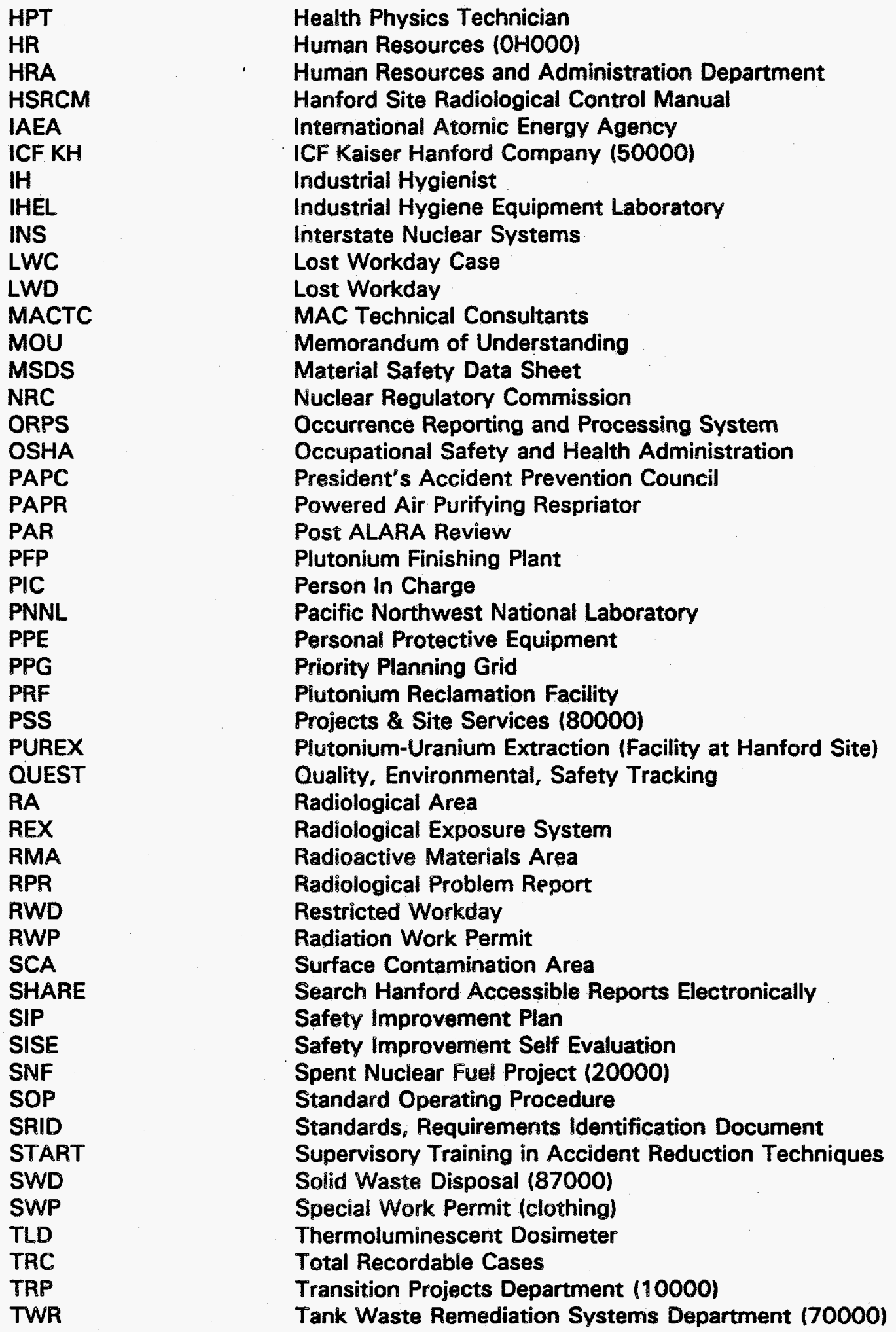




\section{GLOSSARY (Continued)}
TWRS
VPP
VPPPA
WEC
WESF
WHC
WID
WINCO
WRAM
WSRC

\author{
Tank Waste Remediation System \\ Voluntary Protection Program \\ Voluntary Protection Program Participants' Association \\ Westinghouse Electric Corporation \\ Waste Encapsulation and Storage Facility \\ Westinghouse Hanford Company (Richland, WA) \\ Waste Isolation Division (Carlsbad, NM) \\ Westinghouse Idaho Nuclear Company (Idaho Falls, ID) \\ WHC Radiation Area Monitoring \\ Westinghouse Savannah River Company (Aiken, SC)
}

\section{DEFINITIONS OF TERMS}

Davs Away From Work (LWD). Unable to be present in the work environment during the normal work shift as a result of a job-related injury/illness.

First Aid. A nonrecordable occupational injury/illness involving one-time treatment and/or subsequent observation, not ordinarily requiring medical care, even though treatment may be provided by a physician or medically trained person.

Insufficient Volumes. Workers did not provide an acceptable amount of urine for the requested analysis.

Lost Containers. Workers did not return the urine sample containers to the analytical laboratory, or the containers were deficient.

Lost in Laboratory. The analytical laboratory lost the urine sample during the processing.

Lost Workday. A recordable case where the employee cannot perform any or all of normal job duties. Lost workdays include both days away from work and/or days with restricted work activity as defined under "Restricted Workday."

Motor Vehicle Incidence Rate. Number of recordable government motor vehicle accidents $x$ $1,000,000$, divided by actual vehicle miles driven.

Motor Vehicle Dollar-Loss Rate. Government motor vehicle dollar loss $\times 1,000$, divided by actual vehicle miles driven.

No Sample. Workers did not provide a urine sample for a delivered container.

No Show. Worker did not appear for a scheduled medical or test appointment.

Occupational Injury/lilness Incidence Rate. Incidence rates represent the number of occupational injuries/illnesses per 100 full-time workers and were calculated as: (N/EH) $\times 200,000$ where: $N=$ number of injuries/illnesses; $E H=$ total hours worked by all employees during the reporting period; $200,000=$ base for 100 equivalent full-time workers (working 40 hours per week, 50 weeks per year).

Qrganization Code. The organization to which the employee was officially reporting at the time of the report.

Property Loss Rate. Actual government property damage (fire or nonfire) dollar loss $x$ 10,000 , divided by property dollar valuation.

Recordable Case. An occupational injury/lilness resulting in one or more of the following: a fatality, lost workdays, loss of consciousness, restricted work or motion, bone fracture, medical treatment beyond first-aid, transfer to another job, termination of employment, or any illness diagnosed by a physician as work related.

Restricted Workday. Physically or mentally unable to perform all or any part of normal work assignment during all of any part of the normal workday or shift. These are cases where the employee was: 1) Assigned another job on a temporary basis; 2) Worked at a permanent job less than full time: or 3) Worked at permanently assigned job but could not perform all duties normally connected with it. 


\section{GLOSSARY (Continued)}

Severity Rate. 'Severity rates represent the number of days lost or restricted per 100 fulltime workers and were calculated as: $(\mathrm{N} / \mathrm{EH}) \times 200,000$ where $N=$ number of days lost or restricted; $\mathrm{EH}=$ Total hours worked by all employees during the reporting period; $200,000=$ base for 100 equivalent full-time workers (working 40 hours per week, 50 weeks per year). 
WHC-SP-0564-40

\section{DISTRIBUTION}

Number of Copies

5 U.S. Department of Eneray Headquarters (To put in Pouch Mail to Germantown, MD)

J Connelley
W Eckroade
M Gavrilas-Guinn
RH Lasky
CS O'Dell

EH-411

EH-32.1

EM-25

EH-32.1

17 Richland Field Office

$\begin{array}{ll}\text { DH Alexander } & \text { S7-51 } \\ \text { DS Atri } & \text { A5-55 } \\ \text { ST Burnum } & \mathrm{S} 7-53 \\ \text { JE Cavanaugh } & H 4-83 \\ \text { DL Clark } & \mathrm{A} 5-55 \\ \text { RA Douglas } & \mathrm{A} 5-52 \\ \text { L Erickson } & \mathrm{S} 7-53 \\ \text { JB Hall } & \mathrm{A} 5-55 \\ \text { CA Hansen } & \mathrm{S7-41} \\ \text { EW Higgins } & \mathrm{A} 5-58 \\ \text { JE Mecca } & \mathrm{R} 3-79 \\ \text { CA Meyers } & \mathrm{S} 7-54 \\ \text { RL Nelson } & \mathrm{A} 5-55 \\ \text { DL Rice } & \mathrm{A} 5-55 \\ \text { WB Scott } & \mathrm{A} 5-55 \\ \text { AB Sidpara } & \mathrm{S7}-54 \\ \text { DJ Williams } & \mathrm{S7}-54\end{array}$

1 Bechtel Hanford Incorporated

$$
\text { JE Tarpinian }
$$

H4-87

$6 \quad$ Hanford Environmental Health Foundation
R Dowray
$J$ Hein
$\mathrm{H} 1-02$
RH Ronish, MD
$\mathrm{H} 1-76$
$\mathrm{H} 1-75$

3 Defense Nuclear Facility Safety Board

SA Stokes

JW Troan

DM Winters

1 Lockheed Idaho Technologies Company

GG Hall 


\section{Number of Copies \\ DISTRIBUTION (Continued) \\ $2 \quad$ MAC Technical Services \\ CP Saget \\ JR Yesberger

Pacific Northwest Laboratory

$\begin{array}{ll}\text { VL Berndt } & \text { A3-60 } \\ \text { HN Bowers } & \text { K3-66 } \\ \text { JJ Fix } & \text { P7-02 } \\ \text { GR Hoenes } & \text { P7-79 } \\ \text { JR Johnson } & \text { K3-53 } \\ \text { LH Munson } & \text { K3-55 }\end{array}$

1 Professional Analysis, Inc.

BG Watkins

A2-19

1 Brookhaven National Laboratory
BJ Dionne

1

Westinghouse Electric Corporation

JL Gallagher

13 Westinghouse GOCO Radiation Health Protection Committee

CW Bickerstaff - Westinghouse Electric Corporation

B Bindi - Westinghouse Electric Corporation

FB Davis - Westinghouse Savannah River Company

$\mathrm{K}$ Donovan - Waste Isolation Division

T Goff - Waste Isolation Division

D Harward - West Valley Nuclear Services

BG Holmes - Westinghouse Electric Corporation

$G$ Hoovler - Safe Sites of Colorado

F Jordan - Westinghouse Savannah River Company

N Mims - Vivestinghouse Savannah River Company

DJ Newland - Westinghouse Hanford Company

AL Trego - Westinghouse Hanford Company

J Volpe - West Valley Nuclear Services Company

6 Westinghouse GOCo Industrial Hyaiene and Safety Committee

JR Bell - Westinghouse Hanford Company

$\mathrm{CL}$ Cabbil - Westinghouse Savannah River

NL Harris - Bettis Atomic Power Laboratory

P Hoffman - Westinghouse Waste Isolation Division

PA Szalinski - West Valley Nuclear Services

D Whittier - Westinghouse Electric Corporation 
DISTRIBUTION (Continued)

Westinghouse Hanford Company

SE Albin

T1-06

DG Allen

TM Amundson

R2-83

N2-10

CE Anderson

E6-28

LD Arnold

JH Arlsanian

RW Bailey

JD Bateman Jr.

AD Bates

BL Baumann

GD Bazinet

DD Beers

RL Benedetti

LG Bennett

EC Benson

OD Berglund

JC Bickford

GJ Boehnke

RR Borisch

WM Bricker

LC Brown

HL Budweg

DE Bullock

$\mathrm{CL}$ Caldwell

VL Conley

GW Cramer

DS Cunningham

LS Dahlin

MC Davenport

CR Davis

HL Debban

WA Decker Jr.

KJ Dempsey

GL Dunford

GL Eaton

RE Elder

RH Engelmann

RA Eschenbaum

LJ Estey

DL Fischer

DJ Foucault

MR Fox

RC Funderburg

RG Gana

JL Gilbert

SS Glover

R Gonzales

HR Gouge

KW Gray

GB Griffin
Number of Copies 201

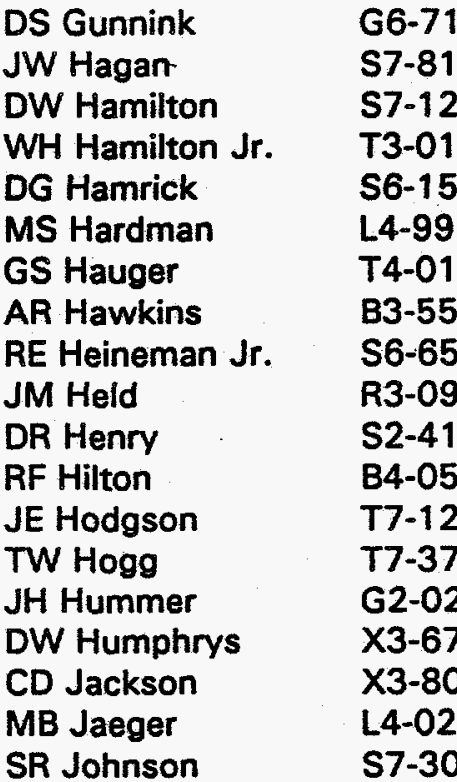

$\begin{array}{ll}\text { SR Johnson } & \text { S7-30 } \\ \text { JL Juette } & \text { G6-56 }\end{array}$

DP Kerwick R2-88

JR Knight B3-63

JS Konyu T7-37

VL Llewellyn T0-06

JE Lindsey T4-08

RR Loeffler $\quad$ \$5-66

BH Lueck S7-81

RL Martin T3-01

DL McCauley B1-10

WJ McKenna B3-30

DW Medley $\quad$ \$4-42

CA Meldrom Jr. $\quad$ T5-02

SL Metzger $\quad$ T3-28

JC Midgett S6-65

CT Miller, II X3-72

TG Miller, III $\quad$ S5-65

RJ Murkowski H5-03

LL Myers B3-07

DR Nunamaker T4-08

AM Ostby T5-03

WL Parnell T4-08

BL Poorman S5-21

PR Prevo N2-10

DN Price $\quad 57-80$

DP Reber T4-08

RD Redekopp T5-15

DL Rittenhouse G3-07

WE Ross \$5-07

NL Sant S5-75

ML Sawyer G6-71 
WHC-SP-0564-40

DISTRIBUTION (Continued)

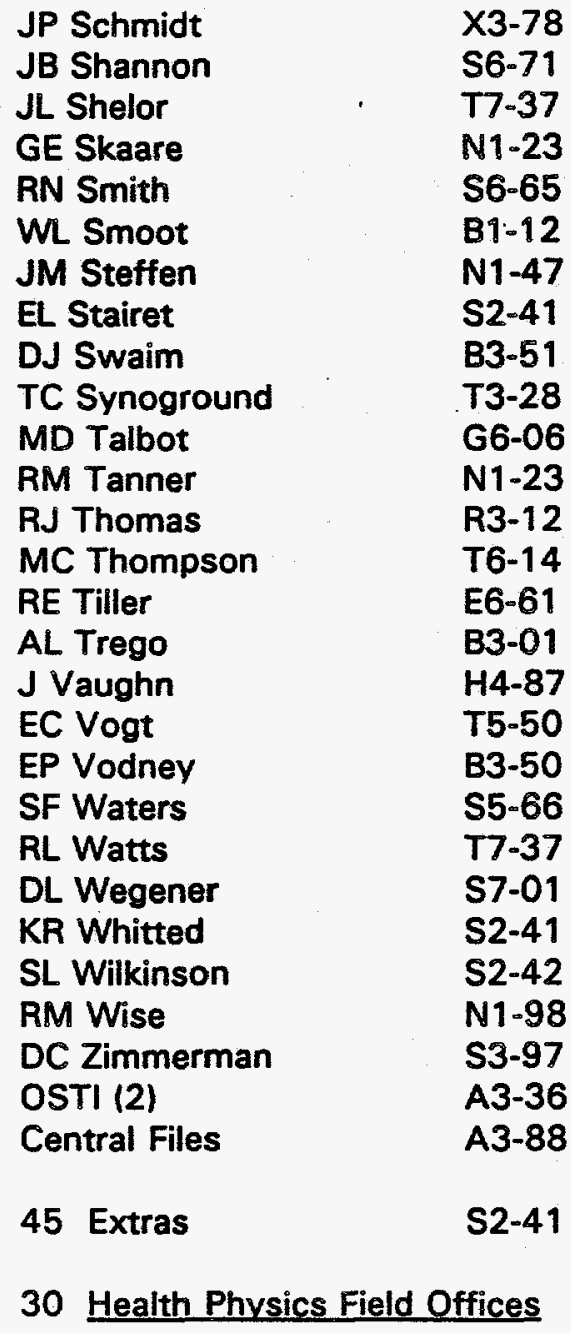

Distr - 4 